DECARCERATING CALIFORNIA: A CRITICAL TRANS POLITICS APPROACH TO EXPANDING INCARCERATED STUDENTS' ACCESS TO UPPERDIVISION COURSEWORK

\author{
45
35 \\ 2018 \\ EDD \\ . R66
A dissertation submitted to the faculty of San Francisco State University
In partial fulfillment of
The Requirements for \\ The Degree \\ Doctor of Education \\ In \\ Educational Leadership
}

by

Roam Romagnoli

San Francisco, California

August 2018 
Copyright by

Roam Romagnoli

2018 


\section{CERTIFICATION OF APPROVAL}

I certify that I have read Decarcerating Califoria: A Critical Trans Politics Approach to Expanding Incarcerated Students' Access to Upper-Division Coursework by Roam Romagnoli, and that in my opinion this work meets the criteria for approving a dissertation submitted in partial fulfillment of the requirements for the degree: Doctor of Education in Educational Leadership at San Francisco State University.

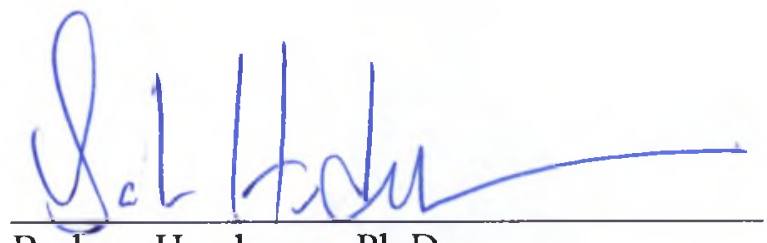

Barbara Henderson, Ph.D.

Director, EDDL

San Francisco State University

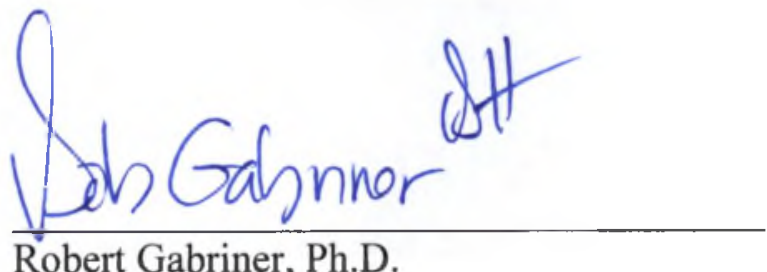

Robert Gabriner, Ph.D.

Professor, EDDL

San Francisco State University

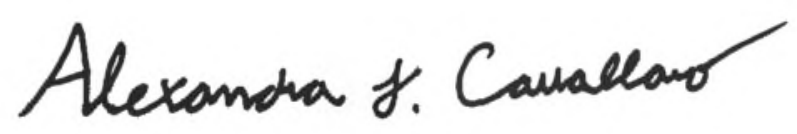

Alexandra Cavallaro, $\mathrm{PhD}$

Professor, English

Cal State University San Bernardino 


\title{
DECARCERATING CALIFORNIA: A CRITICAL TRANS POLITICS APPROACH TO EXPANDING INCARCERATED STUDENTS' ACCESS TO UPPER-DIVISION COURSEWORK
}

\author{
Roam Romagnoli \\ San Francisco State University \\ 2018
}

This dissertation sought to illuminate some of the critical tensions the California Community Colleges face as they are building higher education partnerships with prisons and jails. This study employed queer methodologies (Sheldon, 2010; Browne \& Nash, 2016) in an exploration of the experiences of system-impacted students, as well as the experiences of faculty and program coordinators working in jails and prisons. The research question for this study is: how can California expand incarcerated students' access to upper-division coursework, particularly for incarcerated womxn and queers. This dissertation includes a self-study about my experiences as a White, genderqueer lesbian teaching in a local jail, as well as a second, constructivist grounded theory (Charmaz, 2017) analysis drawn from formal and informal interviews with prison higher education program coordinators, field notes, program literature, and a variety of other data sources. Critical Trans Politics (Spade, 2017) served as an analytical framework for the findings and implications of this study, which means being explicit about the fact that I am an abolitionist, and accordingly, I see rendering prisons obsolete one of the primary purposes of prison higher education programs. This dissertation is a call-to-action for students, faculty, and program coordinators doing the work to bring high-rigor, high-support, open-access, higher education programs to carceral facilities.

I certify that the Abstract is a correct representation of the content of this dissertation.

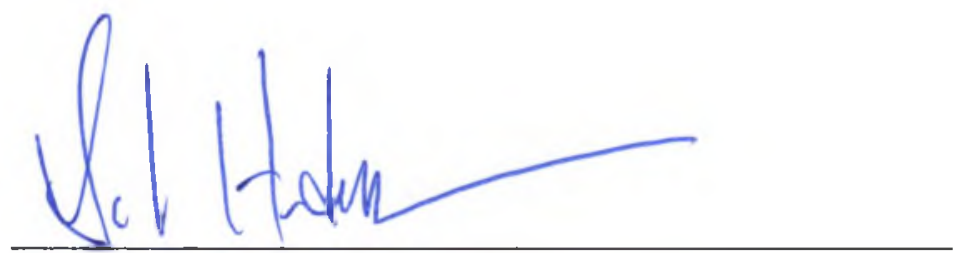

Barbara Henderson, Ph.D. Chair, Dissertation Committee

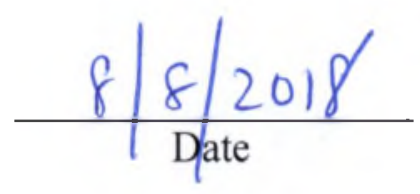




\section{ACKNOWLEDGEMENTS}

To The Order of the Phoenix, which includes but is not limited to:

Tiny, for all of the scenic routes and stops to visit the bison. I will continue to delight in, and be grateful for, every one of our adventures. I can't wait to see what's next.

My therapists (Jill Rees and Angelica Jochim), for being model teachers and model humans-the lessons I've taken from you will serve me, always.

My dissertation committee (Barbara Henderson, Robert Gabriner, and Alexandra

Cavallaro), for being brilliant scholars and transformational leaders.

Team Greatness, for being family; and

My Tia Linda, for showing me all of the beautiful ways education can ruin your life. 


\section{DEDICATION}

This work of straight-up heart is for all of the scholars in my life who I know carry around tiny versions of themselves that have suffered so much at the hands of education, and yet have still committed their lives to transforming these vital spaces of personal and social transformation for others. 


\section{A NOTE ON FORM, STYLE, AND DICTION}

This dissertation study employs Queer Methodologies (Sheldon, 2010;

Browne \& Nash, 2016) and is deeply informed by Critical Trans Politics (Spade, 2015). These theoretical frameworks are manifest in many ways in the organization of this dissertation study, and are directly visible in my writing. Queer methodologies are antipositivist, which means this dissertation is not written in the dispassionate voice of a neutral or "objective" observer. I hope that you will find this writing to be deeply personal and emotional-anti-normative next to traditional modes of research. The write-up of this study also transgresses disciplinary boundaries, as it is deeply grounded in my background in the Humanities, as well as in the Social Sciences. I delighted in the construction of prose that reveal uncomfortable tensions, which works toward the deconstructive aims of queer methodologies. I hope that this dissertation will be as uncomfortable to read as it was to write and that the reader grows as much from experiencing that discomfort as I have. My writing makes visible tensions embedded in word choice; as opposed to conforming to traditional discursive norms, or ignoring tensions that excite me, I have made deliberate decisions to use words that draw direct attention to these fundamental tensions:

- "Prisoner"-I use "prisoner" as opposed to "inmate" or "convict" because of the way "prisoner" implicates the state in an aggressive act, as opposed to the 
individual. I often use "system-impacted" or "previously incarcerated" instead of "ex-convict" for the same reasons.

- "Folx" and "Womxn" - I use these gender neutral terms to carry on the longstanding tradition of using language that disrupts the male/femxle binary. Living in the constant act of deconstructing can be exhausting, especially if you don't have the tools or capacity to create something different. Living in this anxiety led me to critical trans politics, which is a framework for building the world we want to live in, instead of spending all of our energies resisting/deconstructing the world are being handed. I am deeply drawn to the hopeful implications of this type of scholarship, and I worked hard to employ it in my own work.

In line with a critical trans politics approach, I want to be explicit about the fact that this dissertation grows from an imagination I share with other abolitionist scholars of a world without prisons. The aim of this study is to draw practitioners' attention to what my data revealed as some critical tensions in the expansion of California's prison higher education partnerships. Enacting a critical trans politics approach to prison higher education programming means making sure that our programs do not recuperate the prison industrial complex, and that we are providing the most direct-aid to the front lines first. This dissertation is my best attempt at moving California's approach to prison higher education in this (an abolitionist) direction. 
TABLE OF CONTENTS

LIST OF FIGURES ........................................................................................................xiv Chapter One ............................................................................Error! Bookmark not defined.

The Socio-political Context for California's Prison Higher Education Partnerships .Error! Bookmark not defined.

Upper-division Coursework Inside: Disrupting Social Reproduction................... 4 Higher Education for the Front Lines First: Womxn and Queers 1Error! Bookmark not defined.

Invisible History: Queers and the Carceral State.............................15

Queers in the Prison/Education Nexus..................................21

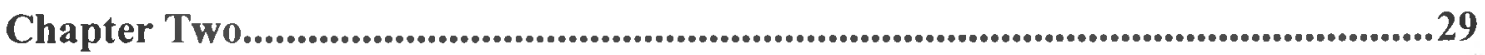

Being Tiny and Becoming Roam: Queerness, Invisibility, and Public Education ...29

Part I: Elementary School ..............................................................................29

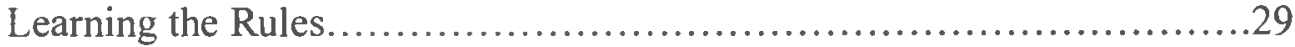

Are you sure?

How will you ever........................................................

Why do you?

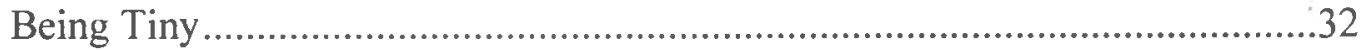

Part II: Welcome to High School .........................................................................35

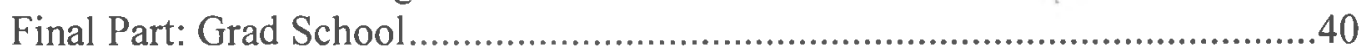

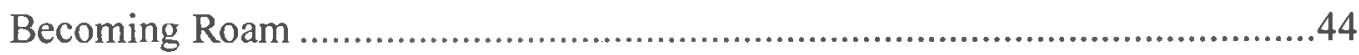

Chapter Three ...........................................................................................................447

Introduction..........................................................4Error! Bookmark not defined.

Experiential Vignettes: Teaching in Jail...........................................................49

\#1: Tuesday and Thursdays Teaching PC males in the jail's main classroom ....49

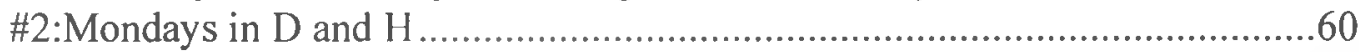

D-Mod............................................................... 60

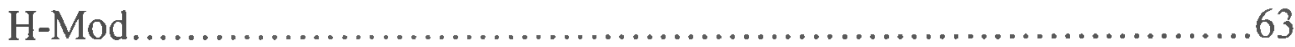

Analysis of Themes: Navigating Identity. Trauma, and Curriculum ...............6Error!

Bookmark not defined.

Navigating Identity: Gender. Sexuality, and Whiteness Inside Correctional

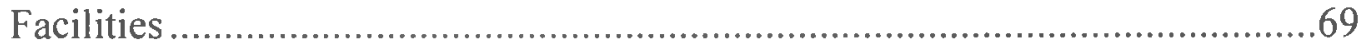

Navigating Trauma: Teaching in the Wounds ..............................................76

Navigating Curriculum as a Trickster Inside: \#JailMail \& Gaming the System.79 
Implications for (especially White) Practitioners in Prison Higher Education 89

Chapter Four..................................................................................................95

A Critical Trans Politics Approach to California's Prison Higher Education Partnerships ...........................................................................................95

Program-level Findings.............................................................................. 100

Finding Area 1: The Funding and Research Climate for California's Prison

Higher Ed Programs.................................................................................1 101

Implications for Critical Trans Politics Approach to Funding Prison Higher

Education Programs............................................................................. 114

Conscious Funding Practices........................................114

Dynamic partnerships for decarceration..............................117

Finding Area 2: Disparities in Quality of Instruction and Student Services.....119

Breadth and Quality of Instruction....................................121

The Absence of Disability Rights and other Student Services..............124

Gender-biased Programming.......................................127

Implications for Critical Trans Politics Approach to Equitable Programming.129

Finding Area 3: Turf Wars between GED, Workforce Prep, and Academic

Pathways ................................................................................. 132

Implications for Critical Trans Politics Approach to the GED/Workforce

Prep/Academic Pathway Divide ......................................................... 147

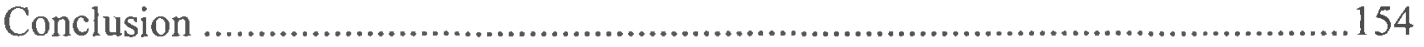

References................................................................................................... 157 
Figure

1. Theodore de Bry Engraving ...................................................................................... 15

2. Still from film Stonewall Uprising ................................................................................ 16

3. Still from film Stonewall Uprising .......................................................................... 17

4. Still from film Stonewall Uprising ................................................................................... 17

5. "No Justice No Pride" Facebook page ........................................................................... 18

6. "No Justice No Pride" Facebook page ....................................................................... 19

7. Lawrence King.....................................................................................................................21

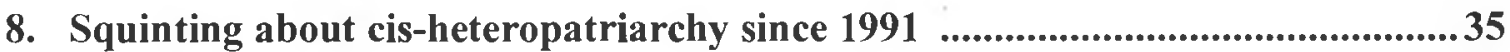

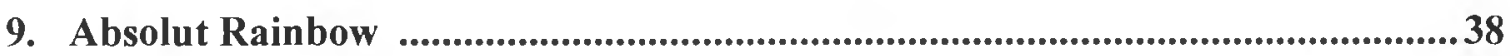

10. Entryway of jail lobby ..............................................................................................51

11. Entryway of central command .............................................................................552

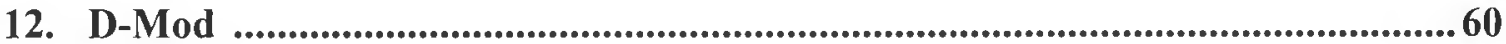

13. \#JailMail: Game the system ......................................................................................79 
Chapter One

\section{The Socio-political Context for California's Prison Higher Education Partnerships}

SB 1391 is the 2014 Senate Bill legislating the California Community Colleges (CCCs) and the California Department of Corrections (CDC) into partnerships aimed at expanding educational programming across California's correctional facilities.

Specifically, SB 1391 reads:

This bill would require the Department of Corrections and Rehabilitation and the Office of the Chancellor of the California Community Colleges, on or before

March 1, 2015, to enter into an interagency agreement to expand access to community college courses that lead to degrees or certificates that result in enhanced workforce skills or transfer to a 4-year university.

As a result of this legislation, a burgeoning number (currently, 18) of California's community colleges are in various stages of implementing education programs in correctional settings; however, the vast majority of these programs have no pathway to transfer beyond 2-year certificates and have little guidance for facing the complexities of providing higher education programming in a correctional environment. Some of these considerations include: hiring and training diverse faculty to deliver critical contextual pedagogy; navigating the unique setting of correctional facilities (e.g., obtaining clearance for faculty and for supplies, providing technology, attaining internet access); striking an agreeable contract between educational and correctional agencies; securing 
funding during times of declining enrollment; maintaining consistency despite the always-in-flux nature of correctional facilities (e.g., inmates and officers are frequently transferred or released, lockdowns can prevent classes from taking place); facing resistance (the public, faculty, and corrections officers often don't believe inmates deserve free education); and most importantly, facilitating broader social and political movements aimed at dismantling structures that perpetuate the prison industrial complex and that work as barriers to decarceration.

While higher education programs in carceral settings are usually started by deeply caring people with good hearts and liberal intentions, these programs also often employ a narrative of personal transformation embedded in promises to reduce recidivism and to return "productive citizens" to society; this narrative reproduces neoliberal ideals of rugged individualism and personal responsibility. Hyper-focusing on the individual using the compelling narrative of personal transformation through higher education allows faculty and program coordinators to ignore — or at least forget momentarily — the fact that even our most highly educated incarcerated students will be released into a society still riddled with systemic biases that will pose significant barriers to their housing, health, further education, and employment. The movement for free prison higher education is further complicated by the distinct and uncomfortable tension between offering liberatory higher education in correctional facilities, and reproducing social inequality-especially when the majority of the field of Prison Higher Education is comprised of White womxn. 
while the majority of incarcerated individuals are from minoritized groups. There is dire need for research that can be used to guide leaders interested in extending California's legislated partnerships between community colleges and correctional facilities to provide incarcerated students with pathways to transfer, where they have access to high quality upper-division coursework and academic degrees. A pathway to transfer has the potential to increase incarcerated students' individual and social agency, to be an avenue toward a healthier and more fulfilling life, and to cultivate political and social agency that can be turned against systems of oppression. Conversely, most of the community college programs operating in California's correctional facilities offer primarily non-credit Adult Education and Workforce Preparation programs, without a pathway to college-level curriculum for the vast majority of prisoners; this is the heart of the problem addressed in this dissertation study.

Santa Rosa Junior College (SRJC), where I teach English and am struggling alongside a dwindling group of faculty to offer credit courses in the local jail, is a prime example of this problem of reducing the function of higher education to employment for incarcerated students. While faculty from myriad academic disciplines across campus have expressed interest in teaching transfer-level curriculum at the jail for several years now, it has been an uphill battle to make this happen. To date, we have only been "allowed" (by administration) to offer non-credit GED and workforce preparation courses funded through the Adult Education Block Grant or the Workforce Innovation and 
Opportunity Act (WIOWA). SRJC recently created an entirely new Adult Education department and approved the following courses specifically to be taught at the jail: Forklift Operator Sitting and Standing; Hardscaping; Green Landscaping; Survey, Building, \& Construction; Customer Service; Intro to Tourism; OSHA 10-Hour Certificate; and Managing Small Business Plan (SRJC Course Catalog, 2018). These new courses demonstrate the college's focus on workforce skills at the jail, which as incarcerated students' only option, effectively restricts the function of higher education to employment for this group of students. To date, like many of the other community colleges offering programming in correctional facilities, this college has not offered a single transfer-level course at the jail and maintains a distinct focus on GED, (genderbiased) workforce preparation, and non-credit remediation. This is precisely where I enter the conversation with my own experience and research in this field. In the next sections, I make the case for the explicit focus of my research on upper-division coursework, as well as my focus on incarcerated womxn and queers in the field of prison higher education.

\section{Upper-Division Coursework Inside: Disrupting Social Reproduction}

The absence of transformative educational opportunities in jails and prisons reflects Freire's banking model of education, which robs students of their humanity by turning them into "empty receptacles"—or repositories for dumping skills. Freire contends that the harder students work at storing the deposits entrusted to them, the less they develop the critical consciousness which would result from their intervention in the 
world as transformers of that world (Freire, 1970). Freire also delineates the underlying values of banking-style education where, "the interests of the oppressors lie in changing the consciousness of the oppressed, not the situation which oppresses them. For the more the oppressed can be led to adapt to that situation, the more easily they can be dominated" (Freire, 1970). Applying Freire's critique to the conversation around higher education for incarcerated students means asking the question: who benefits from relegating incarcerated students to education programs focused on workforce preparation and remediation?

These oppressive education practices work to serve Bourdieu's (1977) theory of social reproduction, which exposes education's contributions to reifying the structure of power relationships between classes by determining the distribution of various forms of capital. Bourdieu considers all pedagogical actions to be symbolic violence, since it is an arbitrary imposition of culture by an arbitrary power. Bourdieu and Passeron (1977) write explicitly about the function of exams in the exclusion and selection of students. Accordingly, in California's community colleges, poor, queer, first-generation, and minority students are the most likely to be placed by a standardized test (the Accuplacer) into the remedial pathway, which means these students are more likely to be relegated to more low-joy, low-wage and low-security jobs than those (White and wealthy) students with immediate access to challenging coursework that inspires their creativity, passion. and inquiry. This reflects another of Bourdieu's theories: the structure of the possibles. or 
space of possibles. The space of possibles can be described as an economy of capitals, where positions are determined by an individual's position in a field of positions. More specifically, Bourdieu is addressing the hierarchical structure of the distributions of social and economic capital, which he refers to as social trajectories or constructed biographies. Higher education programming that focuses on remediation and workforce preparation to the exclusion of other disciplines, prescribes very narrow social trajectories and authors too-limited biographies for certain types of students - a social outcome worth deep interrogation. Bourdieu answers the question of who benefits from limiting education to workforce preparation (the upper class), and he invites interrogation into how (and by whose hands) this happens.

In terms of prison higher education, it is necessary to question both who is shaping the structure of the possibles for our incarcerated students, as well as what are the biographies (futures) being prescribed by enacting those possibilities? These considerations are particularly critical in carceral settings, where predominately White womxn are inculcating (educating) incarcerated minorities into "productive citizens" (aka: White, middle class norms) through a distinct focus on GED and workforce skills, instead of community responsive and problem-posing pedagogies delivered through diverse faculty and across challenging disciplines including (not limited to) ethnic studies, public health, STEM. and critical criminology (the study of the social construction of crime). In these dire and turbulent political times, many contemporary 
cultural critics are returning to Freire and Bourdieu to reveal neoliberalism's corrosive influence on higher education, and as a result, on the health and vibrancy of our social democracy.

For decades, public intellectual and critical education theorist Henry Giroux (2015) has been provoking educators to consider what it means to make pedagogy political by, "being vigilant about those very moments in which identities are being produced and groups are being constituted, or objects are being created". Giroux continues to narrate and critique the war being waged against the very spaces and pedagogical practices that endow critical thinking with political agency. In his call to action for educators, America at War with Itself (2017), he affirms that in a time of increased repression such as this, it is all the more crucial for educators to reject the notion that the university is simply a site for advancing the culture of business. Similar to Freire's banking model and Bourdieu's space of possibles, Giroux dissects pedagogy as a form of symbolic and intellectual violence—one that assaults rather than educates. He lambasts teaching that dulls students' critical impulses and produces what he calls, "dead zones of the imagination....and crippling modes of conformity" (p.7, Giroux).

Remediation is often criticized as a punitive practice precisely for these reasons, since teachers often approach remedial coursework with a drills-and-skills perspective, focusing on grammar and sentence-level development. Students that are sentenced to remedial pathways rarely make it to transfer-level courses. which effectively denies these 
students access to crucial skills and forms of capital, and ultimately, degrades the quality of our democracy.

Giroux (2017) reminds educators that education and pedagogy do not exist outside of relations of power, values, and politics; that educators are, in fact, engaged in a politics of possibility, and that critical pedagogy is a project of insurrectional democracy. Like Bourdieu, Giroux argues that the most important forms of domination are not only economic, but also intellectual and pedagogical. This is something that Cornel West, who has been teaching in prisons for 37 years, has been preaching about for decades in the realms of academe, but that has only recently become part of the larger discourse around the function of higher education for incarcerated students.

In a 2016 talk titled, "The Examined Life", Princeton philosophers Robert P. George and Cornel West address the impacts of neoliberal forces on higher education and respond to the question, "What is the point of a liberal arts education?" Both philosophers agree that market forces have reduced the function of higher education to income attainment; they assert that the elimination of humanities to focus on business, skills, and profit represents a flaw in our collective values that prioritize profit over people. The solution to what Cornel West calls a moral crisis or spiritual blackout, is disrupting this move away from humanities toward workforce skills - of course, not to the exclusion of preparing students with a diverse array of skills. West implores us to question the instrumentalization of knowledge and education to some cause other than what he calls, 
"the examined life"-which, he argues, can happen through higher education that includes the humanities, where our sense of what it means to be human isn't reduced to money-making. In the speech, West outlines some of the human virtues students explore in liberal arts courses: justice, courage, discipline, self-sacrifice, integrity, honesty, and what he calls "kenosis", or the courage to empty yourself by serving others. Previously, prison higher education research has focused on justifying itself by using data to prove that offering incarcerated students higher education will decrease recidivism, will increase post-release employment, will save taxpayer money, and will improve correctional environments. Of late, prison higher education research is beginning to beg new questions about the purpose of higher education inside; like, which members of our society deserve the privilege of living an examined life?

Prison educator and researcher Clint Smith (2017a) recently published an essay in The Harvard Review titled, "Complex Sentences: Searching for the Purpose of Education Inside a Massachusetts State Prison." His essay was also excerpted in a (2017b) article in The Atlantic titled, "The Lifelong Learning of Lifelong Inmates." Smith contends that people in prison deserve education because the project of learning should be understood as a human right that every individual should be afforded since, "it isn't merely something that attains its value through its presumed social utility—or, worse, that society can take away from an individual who"s convicted of breaking the social contract" (p.1, Smith). Smith's essay concludes: 
These men are not perfect. They are complicated. They have made mistakes. In other words, they are human. And it is precisely this humanity that demands a space where they can ask and question and create and grapple with all that makes the world what it is-a place where social and intellectual community might be restored in a way that reestablishes an individual's agency. The agency a carceral institution inherently attempts to strip away (p. 7).

Clint Smith, Robert George, and Cornel West's philosophies are largely grounded in (not limited to) a Christian service/moral crisis paradigm that focuses on transforming individuals and resisting the evil marketizing forces of capitalism that infect our thinking about higher education; their critiques can be operationalized by moving beyond theorizing resistance toward actually creating the revolution we want.

In their recent conversation, Michelle Alexander, Naomi Klein, and KeeangaYamahtta Taylor (2017) discuss the inherently defensive rhetorical premise of the idea that we have to resist forces (like neoliberalism) targeting our public values and spaces. Instead, these revolutionaries argue that on this stolen land, in a nation born of slavery and genocide, the question is how we can build a multi-racial, multi-ethnic, multi-faith, multi-gender. egalitarian democracy. In order to achieve this democracy, they argue, we will have to stop playing defense and ourselves create an economy and legislation that ensure every human has their basic needs met like education, housing, healthcare, and opportunities to do meaningful work at a living wage. Alexander et al. prescribe local, 
grassroots versions of people's platforms rooted in a culture of radical care and consent enacted through reparations and redistribution (specifically, of wealth); they delineate that those most harmed by mass incarceration and neoliberalism should not only have a voice in the revolutionary process of transformation, but should emerge as leaders.

Alexander, Klein, and Taylor (2017) advise leaders to create the kind of democracy we want on a local scale; I see my research project as an opportunity to enact transformation at local and state levels through programming and policy aimed at educational justice. When Alexander, Klein, and Taylor say that this project of transformation "will require us to open our hearts and minds to those we have been taught are "others", beyond our care and concern", I think of the 30 prisons that sit off of 5 freeway in Central California, each of which holds thousands of humans. This is also where the world's two largest womxn's facilities exist, directly across the street from one another. Many Californians avoid the dystopian desert of the 5 freeway at all costs and have no idea so many prisons exist just out of sight from the highway, which leaves many of these incarcerated individuals beyond our care and concern.

Like Robert George and Cornel West, Alexander et al. (2017) remind us that we live in a time of unprecedented private wealth, yet we are conditioned to believe that meeting people's needs with programs like universal healthcare and free higher education for all is a utopian pipe dream. Meanwhile, our government continues to expand funding for a militarized expansion of the wars on drugs, immigration, and terror. while reducing 
social services for the most vulnerable members of our society. This is a terrifying time for our larger social democracy, especially for minoritized groups, and our local programs and institutions of higher education continue to be some of the most contested sites in the redistribution of power, agency, and capital.

The community colleges' tri-part mission makes these institutions intricately intertwined with the intellectual, social, and economic development of the nation in that they simultaneously provide transfer, community education, vocational skills, and various forms of workforce preparation; accordingly, community college academic programming and legislative policy can have immense impact on students' life chances, or spaces of possibles. If all we offer incarcerated students is opportunities to become forklift operators and hardscapers, how will they ever know if they might also enjoy life as public health experts, or botanists, or critical educators? To be clear, my intention is not to criticize or devalue the work of forklift operators. It is my desire to expand incarcerated students' access to more spaces of more possibles. My commitment to focusing on higher education for incarcerated womxn and queers is my attempt at achieving justice, as Alexander et al. (2017) recommend, for the front-lines first.

\section{Higher Education for the Front Lines First: Womxn and Queers}

Access to liberatory higher education while inside is particularly important for incarcerated womxn and queers with intersectional oppressions, which form more considerable threats to safety. housing. healthcare. education, and employment upon 
release (Mogul, Ritchie, \& Whitlock, 2011; Spade, 2015; Stanley \& Smith, 2015). The opportunity to attain higher education while incarcerated enables these hyper-exploited individuals to prioritize education, as opposed to say, safety. For example, Richie (1996) reveals that when compared to their Black male counterparts, Black girls are much more likely to be sexually assaulted in both the public and private sphere and they are less likely to be protected by the adults in their lives. There is a burgeoning body of research around Black girls in the pipeline to prison. Black girls are $16 \%$ of the femxle student population, but nearly one-third of all girls referred to law enforcement and more than one-third of all femxle school-based arrests, according to Pushout: The criminalization of Black girls in schools (Morris, Conteh, \& Harris-Perry, 2018). A second recently released book, Invisible No More: Police violence against Black women and women of color (Ritchie, 2017), also offers critical insight into the historic and contemporary plunder of Black femaxle bodies by the prison industrial complex. Both of these books also draw attention to the role of campus police in funneling Black girls into the pipeline to prison.

Trans people, particularly trans womxn of color, experience some of the most extreme vulnerability because more aspects of their lives (public restrooms, schools, prisons, welfare programs, foster care, drug treatment centers, homeless shelters, and job training centers) are directly controlled by legal and administrative systems of gender binaries. The most marginalized trans people have the least protection from violence, experience more beatings and rape, are more likely to participate in criminalized sex 
work, are imprisoned at extremely high rates, and are more likely to be disappeared and killed (Spade, 2015. Access to liberatory education is critical for individuals, like Black womxn and trans individuals, that have never known a time of reprieve from statesanctioned violence. There is abundant research exploring the abuse of Black men by the criminal justice system and a growing body of research exploring the brutalization of Black womxn and girls by the police state; however, there is limited literature interrogating the intersections of queer identity, education, and the prison industrial complex. Releasing womxn and queers from prison without providing them with access to upper-division coursework ensures these individuals will be reincarcerated and will continue to be punished for "deviance" from state-sponsored norms around gender and sexuality. Queers have never truly known freedom in these United States, or had our history reflected in academic spaces, which informs my decision to include the following discussion around the intersections of queer identity, public education, and the carceral state. 


\section{Invisible History: Queers and the Carceral State}

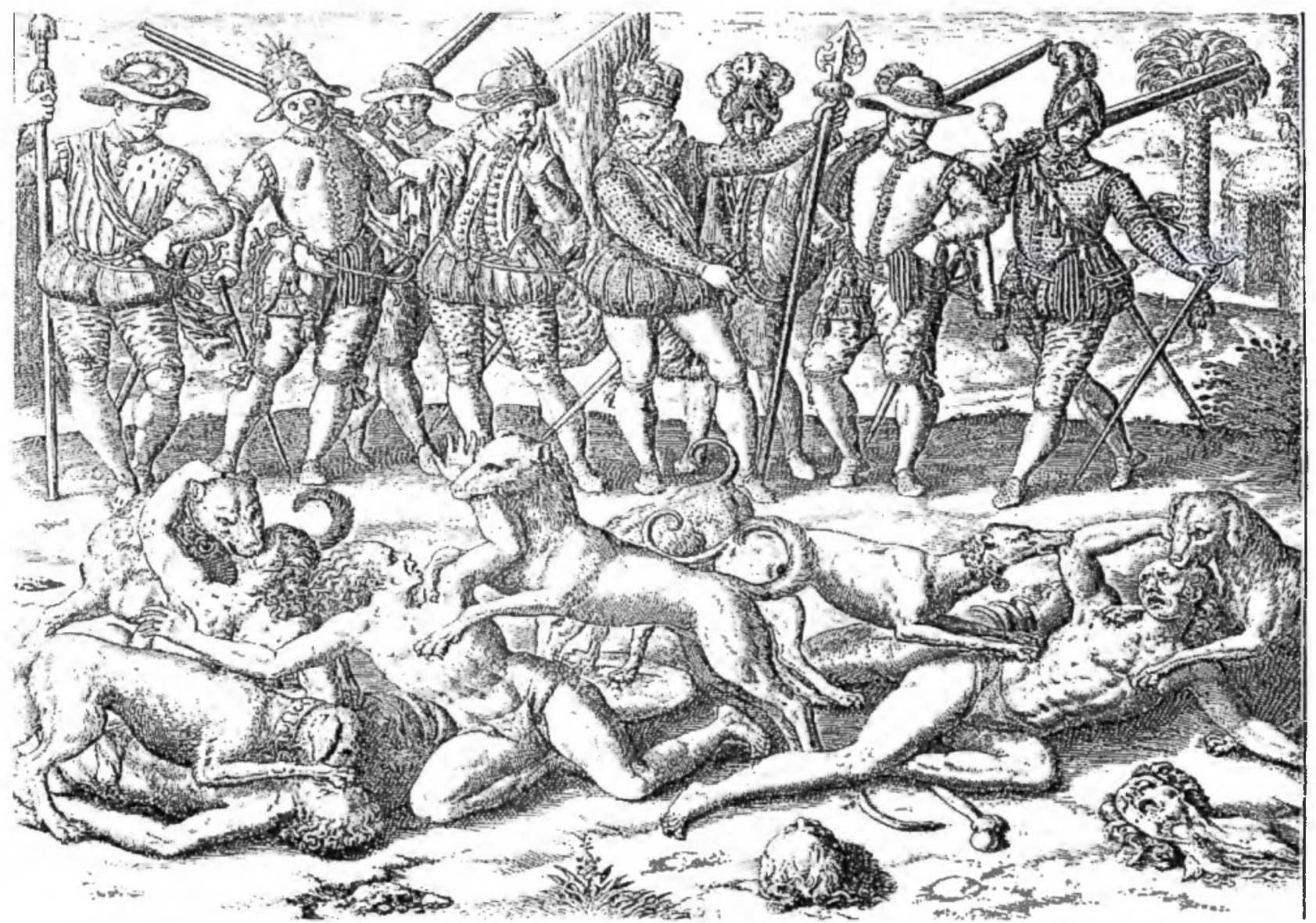

Figure 1. Theodore de Bry, Engraving: Vasco Nunez de Balboa releases hunting dogs to dismember forty of the Indigenous men of Quaraca-all men accused of "dressing like women" and of having sex with one another. (1594)

What is now known as the United States has never existed without the brutalization of queer people by colonizing forces. Theodore de Bry's 1594 engraving immortalizes the moment colonizers began using gender and sexuality as tools of oppression against Indigenous peoples. De Bry memorializes Spanish conquistador Vasco Nunez de Balboa as he releases his hunting dogs to dismember forty of the 
Indigenous men of Quaraca—all men accused of "dressing like womxn" and of having sex with one another. In Queer (In) Justice: The Criminalization of LGBT People in the United States (2011), Mogul et al. illuminate the ways in which policing in America cannot be disentangled from America's history of anti-queerness:

From the first point of contact with European colonizers-long before modern lesbian, gay, bisexual, transgender, or queer identities were formed and vilifiedIndigenous peoples, enslaved Africans, and immigrants, particularly immigrants of color, were systematically policed and punished based on actual or projected 'deviant' sexualities and gender expressions, as an integral part of colonization, genocide, and enslavement (p.1).

This operationalizing of systemic police violence against queers can be traced throughout American history directly to today's conversations about the "pipeline to prison". In the 1960's, four hundred years after de Bry's engraving, artists were still memorializing state violence against the queer community at the Stonewall Riots in New York City. The pictures below are stills from the film Stonewall Uprising (2010). 


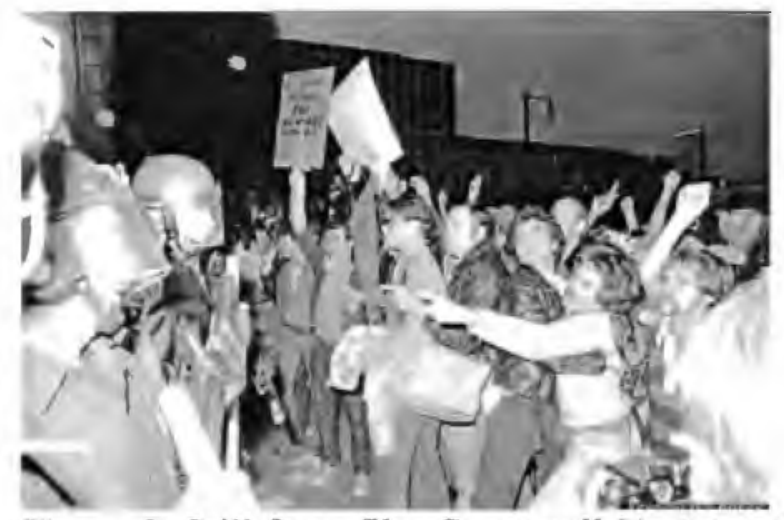

Figure 2: Still from film Stonewall Uprising (2010)

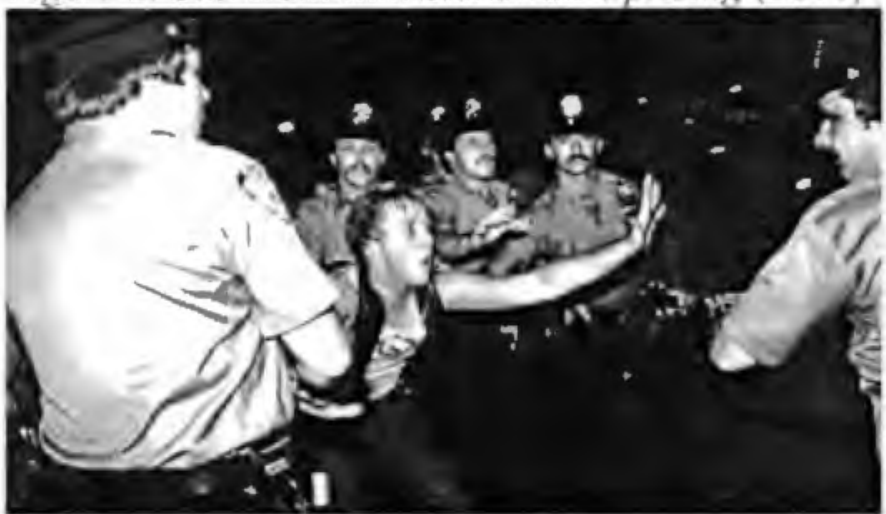

Figure 3: Still from film Stonewall Uprising (2010)

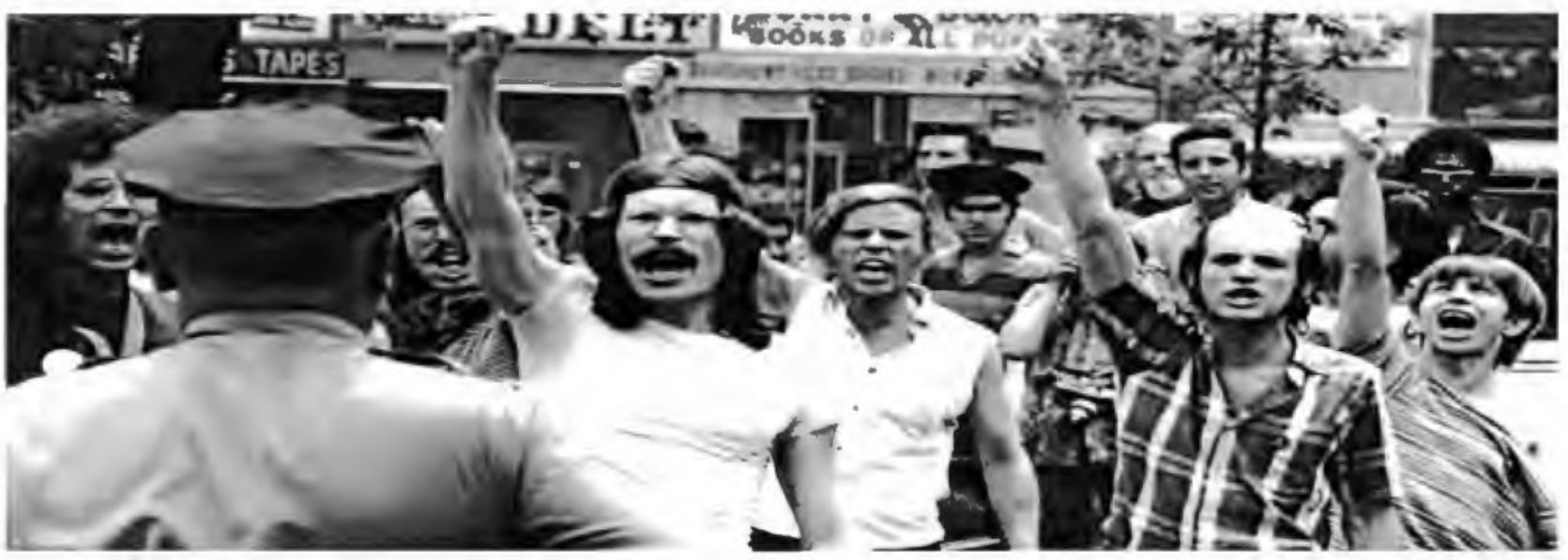

Figure 4: Still from film Stonewall Uprising (2010) 
Although queers have been struggling under the oppressive arm of the state for the entire duration of America's colonial history, the Stonewall raid is often considered the birthplace of the modern struggle for queer rights in America. The Stonewall riots were a series of violent demonstrations by queers in response to a June 28,1969 police raid of The Stonewall Inn, which was one of few public spaces at that time that openly welcomed queer people. Many queer people and allies celebrate "Pride" every June by wearing rainbows to massive parades and by taking shots of Absolut Rainbow at festivals, without ever realizing that the first Pride took place on June 28, 1970 to commemorate the anniversary of a riot against the police brutality inflicted on the queer community by cops. On the heels of the Pulse nightclub massacre, and in response to the current political climate of rampant cis/hetero White male supremacy, the tension between queer liberation and the police state has been increasingly visible in recent Pride festivities. The images captured below from the "No Justice No Pride" Facebook page demonstrate the divisiveness in the queer community about what our relationship should be to the police; largely, liberal gays want pro-gay police marching in pride parades and driving cop cars with rainbows painted on the doors. Radical queers intent on remembering this history, see no room for police at pride, or anywhere else. These images from the "No Justice No Pride" Facebook page (2017) demonstrate this conflict: 


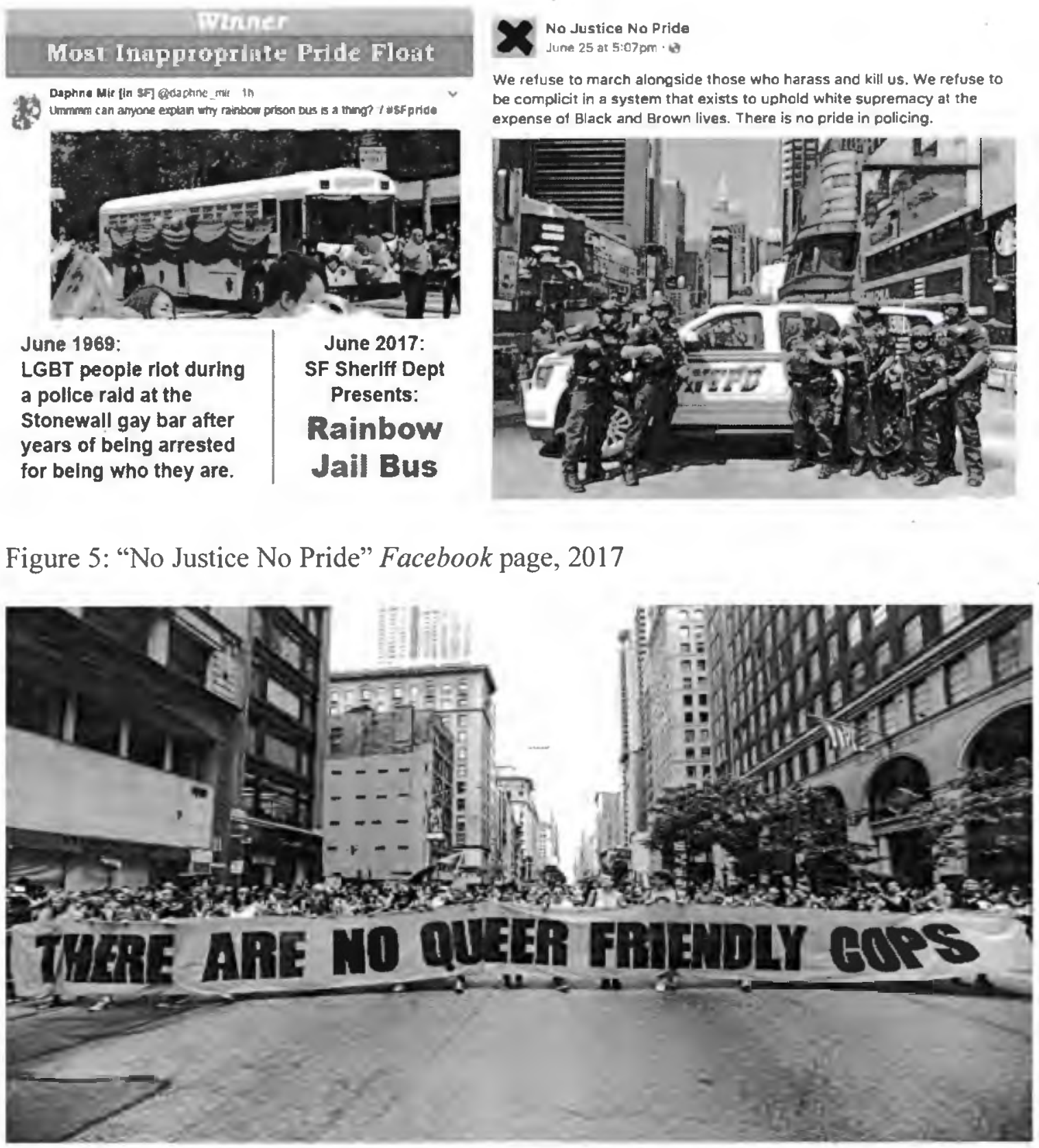

Figure 6: "No Justice No Pride" Facebook page. 2017

While queers have attained some of the civil rights we've been fighting for, there is still a great deal of work to be done-especially in terms of our systems of education 
and in/justice, or the prison/education nexus, where queers continue to be disproportionately funneled out of public schools and into prisons. This is especially wrong since, for many queers, educational spaces can be crucial sites of safety and relief from violent streets and homes. This timing is also pertinent since the current administration's renewed war on drugs, reduction of social services, expansion of militarism and ICE to target immigrants, invisibilization of queers (from the census, for example), and reliance on the neoliberal ideologies of personal responsibility and individual freedoms have struck terror into the hearts of many queers - many of whom were just sinking into the frail, now in jeopardy, comforts afforded by the legalization of gay marriage in 2015 .

Discrimination against queers is often grounded in heteronormativity: the belief and practice that heterosexuality, gender conformity, and traditional family structures are the only correct way of existing in our society (Oswald, Blume, \& Marks, 2005). This belief demonizes queer people and privileges heterosexuals through laws, traditions, and everyday practices that play out in all of our institutions-especially schools. The violence being done to queer people in spaces of education is a critical site for exploration because without a deeper understanding of the relationships between queer, carceral, and academic identities, beautiful queer lives will continue to be sacrificed to a system that is more concerned with the profit to be made by caging, shaming, and exploiting queers than with cultivating the weirdness, creativity, and intellectual dexterity 
that make queers such valuable assets to society. Finding a solution to this problem requires a better understanding of the role education is currently playing in funneling queer individuals out of educational spaces and into the streets, where they are more likely to end up exploited by the prison industrial complex.

\section{Queers in the Prison/Education Nexus}

In 2008 , I was a program coordinator in the school district in southern California where a classmate shot 15-year-old Lawrence King twice in the back of the head in a computer lab, in front of his classmates, for being queer. This event undoubtedly traumatized an entire generation or more of students, staff, and even distant district office personnel like myself. Three years prior to his murder, at the age of 12, Lawrence had already been arrested and put on probation.

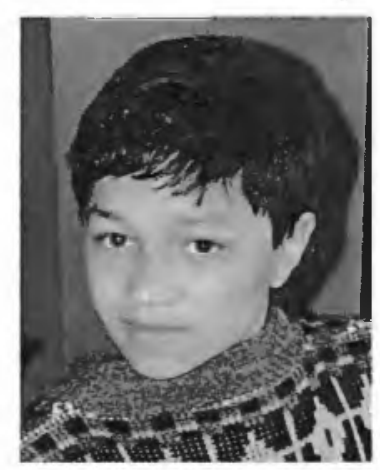

Figure 7: Lawrence King

Research demonstrates that the queer population is more at risk for mental health issues, not because they are members of this sexual minority group, but as a result of "environmental responses to their sexual orientation" (Oswalt \& Wyatt, 2011). Educational environments, in particular. are critical determiners of a child's 
success and wellness - and for queer youth, there is a dire need that is not currently being met in education. Educational environments often ignore, exacerbate, and/or reproduce violence against queer students (and faculty) instead of working to eliminate it. A broad base of research exists documenting the harms that school-based mistreatment can inflict on queer students (Almeida et al., 2009; Birkett, Espelage, \& Koenig, 2009; GLSEN Climate Survey, 2015; Hershberger \& D’augelli 1995); this body of research illuminates two critical components of schools' climates that push queer students out:

1. Harassment (Bullying and Cyberbullying)

2. Disproportionate Discipline

LGBTQ students often face harassment from classmates, and even staff, about their actual or perceived sexual and/or gender identity; of course, this harassment has a negative impact on queer students' psychological, social, and academic wellness. Research reveals a relationship between a history of sexual orientation victimization and mental health symptoms, including increased trauma-related symptoms (D'Augelli, Grossman, \& Starks, 2006) and anti-LGBT victimization in school is strongly associated with substance abuse (Huebner, Thoma, \& Neilands, 2015). Queer students can't win-if they are in the closet, they are likely to battle depression. If they are out of the closet, they are likely to face open hostility from students and school personnel. There are connections between the level of harassment queer students face and their physical and psychological well-being. Research also demonstrates a positive correlation between a 
student's level of "outness" and the extent to which they report being harassed at school, and found that greater victimization was related to negative academic outcomes (Kosciw, Gretak, \& Palmer, 2014; Kosciw, Palmer, \& Kull, 2015). This anti-queer climate in education is a problem that most campuses have failed to solve in spite of decades of research.

There are demonstrable connections between an individual's school discipline record and their likelihood of incarceration. There is abundant research, even a 2014 Civil Rights report released by the US Department of Education, recognizing how punitive discipline disproportionately impacts youth of color, specifically Black and Latinx males. Emerging research (GLSEN, 2015; Snapp, Hoenig, Fields, \& Russell, 2015) continues to indicate that additional groups of minorities, specifically LGBTQ and gender nonconforming students, are also pushed into the prison pipeline through discriminatory discipline practices. GLSEN's (2015) National School Climate Survey included 7,898 students between the ages of 13 and 21 , and $58.8 \%$ identified as LGBT. Fifty-five percent of LGBT students in this study reported experiencing LGBTrelated discriminatory policies or practices at school, like being disciplined for public displays of affection that were not disciplined for non-LGBT students. This study draws attention to several of the most critical effects of these hostile educational environments: those who experienced LGBT discrimination at school were more than three times as likely to have missed school in the past month as those who had not. LGBTQ youth are 
also punished for public displays of affection and for violating gender norms. Further, as a result of hostile school climates, queer youth are under particular scrutiny, are prone to fighting (to defend themselves), and are often blamed for their own bullying. In addition to toxic school environments, family rejection and homelessness can facilitate entry into the pipeline to prison for queers (Snapp et al.). When forced into the streets, queers are then often the likely victims of discrimination by the criminal in/justice system.

Discriminatory disciplinary practices push queer students off of campuses and into the streets, where they are faced with even more dangerous threats to their health, safety, and freedom. A National Longitudinal Study of Adolescent Health (2015) revealed that queer youth had greater odds of being stopped by the police than their counterparts. Similar trends were also observed for school expulsion, juvenile arrest and conviction, and adult conviction. Queer girls were at the highest risk for all of these sanctions. Queer youth are more likely to have been suspended and more likely to have been in corrections; further, gender and sexual minority youth face higher rates of punitive and exclusionary discipline in the form of school suspension and juvenile justice system involvement compared to heterosexual youth (Poteat, Scheer, \& Chong, 2016). For these reasons, it is important to expand on the body of research that currently focuses primarily on the voices and academic identities of Black men to include deep exploration of the academic identities of formerly and currently incarcerated queer individuals and womxn. Increased research on. and deeper understanding of, the experiences of queers in 
systems of education and incarceration can expand our capacity to improve both of these environments for all minoritized groups.

A primary gap in the literature is consideration for the educational experiences of incarcerated transgender adults; there is even less (if any at all, I found no) extant research reflecting the experiences of transgender adults participating in prison higher education programs. Although there are surely similarities in the experiences of LGB and transgender individuals in terms of education and incarceration, there are also surely differences between these two groups. In young people, for example, when compared with their LGB peers, transgender youth report more frequent harassment, face greater amounts of marginalization and isolation, are less likely to feel a sense of belongingness, and have less access to information about transgender issues or persons in the school (Hackimer \& Proctor, 2015; Toomey, Ryan, Diaz, \& Russell, 2011). Further, transgender youth also report experiencing conflict and distress from victimization that is based on both gender presentation and assumed homosexuality (McGuire, Anderson, Toomey, \& Russell, 2010). It is likely that trans adults have similar experiences, which are likely exacerbated in carceral settings where gender and sexual orientation are heavily policed.

Trans individuals in womxn's prisons, for example, are often forced to conform to feminine gender norms. Lori Girshick's “Out of Compliance: Masculine-identified people in womxn's prisons" (2011), which is included in a collection of essays titled, Captive Genders: Trans Embodiment and the Prison Industrial Complex, shares the 
stories of trans individuals housed in two of the biggest womxn's facilities on the planet (across the street from one another in Chowchilla, California). Girshick illustrates that both men's and womxn's facilities mirror a hyper-expression of gender roles in society. Men's institutions are designed to be violent, to reinforce the hyper-masculinity of competition, dominance, control, force, suppression of emotion or weakness, and especially heterosexuality, where punks or "womxn," are forced into sexual submission. Conversely, womxn's institutions expect womxn to be passive, emotional, weak, submissive, and dependent. Since nonfeminine behavior landed them in prison, incarceration is aimed at restoring them to it. Incarcerated womxn should display subservient behavior, including in heterosexual relations. According to Girshick:

Due to the constant monitoring of sexual behavior (where any touching between prisoners can be defined as sexual) and the fact that more guards are male than female, there is a highly sexualized environment that includes flirting between male guards and prisoners, whether due to dependence on them for access to goods and privileges or in search of attention, kindness, or father figures. This dependence mirrors the traditional relationship outside of the prison in which women are supposed to be at the beck and call of men in their lives (p. 217). In addition to restricting womxn's behavior, correctional facilities also use clothing as a way to enforce strict gender norms. Trans individuals incarcerated at womxn's institutions can be forced to wear womxn's clothing. including panties and 
form-fitting clothing; they tell stories of the shame involved with being forced to wear muumuus when transferred to a new facility or with being harassed by male guards saying things like, "How much of a man are you?" and "So how big is your dick? I bet mine is bigger," (Stanley \& Smith, 2015). This is not just something that happens to incarcerated trans people; I've been asked questions like these in places like coffee shops and grocery stores. In, "Being an Incarcerated Transperson: Shouldn't people care?", Clifton Goring/Candi Raine Sweet recounts their experiences, "being cut by other prisoners for refusing to perform sexual acts for them" and having "been beaten and sexually assaulted [sodomized with the nightstick] by correctional staff" (Stanley \& Smith). The abuse that trans prisoners face at the hands of guards is demonstrative of a larger pattern in trans existence: many trans individuals have one incredibly terrible thing in common, which is the fear of being harmed by the very ones who are there to protect us - in this case, the police.

The impact of the prison-industrial complex is, for some, made much more pernicious by gender violence coupled with queer sexuality - the current formulations of the social costs of imprisonment that tend to minimize questions of gender and ignore sexuality altogether render queer prisoners, crimes related to nonnormative sexuality, and violence against incarcerated womxn invisible to even the most activist-oriented communities of resistance (Richie, 1996). While attacking preexisting conditions, our government is simultaneously funding the hyper-militarization of police, which cause 
many of those very preexisting conditions: this is a complex assault on womxn and queer individuals — particularly those of us from communities most-often brutalized by police, by family, and by neighbors. With this in mind, I decided to situate my own study in a Critical Trans Politics approach in order to expand established research paradigms, to offer a more precise critique of Prison Higher Education in California, and to help transform the nature of the conversation around prison higher education in California's correctional facilities.

Overall, this project interrogates the process of expanding incarcerated students' access to upper-division coursework with a deliberate focus on incarcerated individuals representing some of society's most marginalized populations. The research question for this study is: how can California expand incarcerated students' access to high-quality upper-division coursework, particularly for incarcerated womxn and queers? The second chapter of this study is an autobiographical account of my own experiences as a queer living and working in the intersections of public higher education and incarceration. The third chapter is a self-study of my experiences as a queer community college English professor working to build a transfer program in a local jail. The final chapter will includes findings and implications grounded in my own experiences, as well as in dozens of both formal and informal interviews with prison higher education policy experts, program coordinators. faculty, and students all working in this field up and down the state and across the nation. 
Chapter Two

Being Tiny and Becoming Roam: Queerness, Invisibility, and Public Education The following memoir is about my experiences, but it is not just about my experiences. Womxn and Queer folx continue to face extraordinary barriers to healthy family, education, and community environments, which leaves us underrepresented in leadership positions and graduations, while overrepresented in homeless shelters and in the criminal justice system.

\section{Part I: Elementary School}

\section{Learning the Rules}

No, you can't wear your brother's clothes.

Yes, you have to wear a dress.

No, you can't be an altar boy.

Yes, you have to do the dishes.

No, you can't pull weeds instead.

Yes, you have be in before dark.

No, you cannot be in the boy's line.

Yes, you have to play softball.

No, you cannot play baseball.

Yes, you have to take home ec.

No, you cannot take anything with the word "shop" in it instead. 
Yes, you have to wear a bra.

No, you cannot wear pants and a hoodie instead.

Yes, you must go shopping with your mom.

No, you cannot lay bricks with your dad.

\section{Are You Sure?}

Are you sure you want to wear that?

Are you sure you don't want to be more like the other girls?

Are you sure people won't think you're a boy?

Are you sure you want to cut your hair like that?

Are you sure you don't want to have kids?

Are you sure you won't be sorry?

Are you sure you are in the right restroom?

Are you sure you weren't abused as a child?

Are you sure you're not depressed?

Are you sure it's not just a phase?

Are you sure you just haven't met the right man?

Are you sure you're not imagining it?

Are you sure you don't care about what people might think about you?

Are you transgender?

Are you sure? 


\section{How Will You Ever}

How will you ever find a man?

How will you ever have a normal life?

How will you ever get a real job?

How will you ever fit in?

How will you ever feel safe?

How will you ever earn people's respect?

How will you ever have a healthy relationship?

How will you ever feel comfortable in your own skin?

How will you ever be taken seriously as a leader?

\section{Why Do You?}

Why do you want to be a man?

Why do you dress like a man?

Why do you look like that if you don't want people to think you're a man?

Why don't you act like a lady?

Why don't you dress like a lady?

Why don't you eat like a lady?

Why don't you sit like a lady?

Why don't you work a little harder to just fit in?

Why do you insist on making people uncomfortable? 
Why can't you be a normal womxn?

Why do you have to put your sexuality in my face?

Why are you so angry?

Because:

The incessant assault on queer lives is exhausting.

\section{Being Tiny}

I was nine the first time I leaned over the olive-green tile of my parents' bathroom sink, stared into my own small wet eyes in the mirror, and thought of taking my life before heading off to school.

This would become an almost-daily ritual...

But it wasn't always that way.

You see, I grew up with two older brothers, which meant hand me downs and bmx bikes, and frog hunting, and pink-belly and typewriter chest, and skateboard ramps with crossbones, and swimming in quarries, and sneaking to liquor stores for candy and soda, and dirt bikes, and playboy magazines and cigarettes in forts, and basically, the best life ever, right?

A boy's life.

For a short time, it was acceptable for me to live that life-it was momentarily tolerable for me to be a tomboy. But, my home life and interests sat in direct conflict with 
what I faced in school, where I was crammed into a dress and into the prison of girlhood for the first time in my tiny life:

the girls' line, and girls' sports, and girls' clothes, and girl talk, and girls' restrooms, and girls' accessories (not toys anymore), and girls' health education, and girls' movies and girls' books and girls' tv shows, and girls' norms for bodies and desires and behaviors.

For my brothers, and most other cis-hetero White boys, school was their personal kingdom; the first day of school every fall presented them with limitless and exciting possibilities for adventure, for intellectual engagement, for physical outdoor activity, and... well, for relationships with girls. They got to carry on living that dream life we enjoyed at home, even at school.

For me, school was a direct portal to too-big, too-ancient anxiety and depression for my tiny self to understand.

Over my life, l've spent more hours in schools than in any other space. Schools have been the places where l've felt the safest, and schools have also been the spaces where I've experienced the most violence and felt the.most terror.

The first time a boy called me a dyke at school, we were in the third grade.

I knew I could not cry.

Or tell my teacher.

Or any of my friends. 
Or anyone in my family.

At that moment, even though I had never heard that word before and had no clue what it meant,

I knew he was right.

And I knew somehow, deep in my guts, that my very survival would now depend on my ability to hide whatever it was that had given me away. After that moment, the process of invisibilizing the queer parts of my identity—especially at school—consumed every ounce of my energy and attention.

My cisgender, heteronormative brothers, and most other boys, got to feel free at school.

1 felt like dying. Daily.

And, I couldn't understand why.

It took me many, many years to figure out that it wasn't school itself or learning that I hated or that made me feel that way-it was that I was exhausted by all of the energy and attention I had to put into hiding who I was. It also took me many years to disentangle my gender identity from my sexuality, since they were both parts of me that society told me were shameful. I spent elementary school consumed entirely with my own survival. Surely high school couldn't be so bad, right? After all, I would finally be headed to public school... 


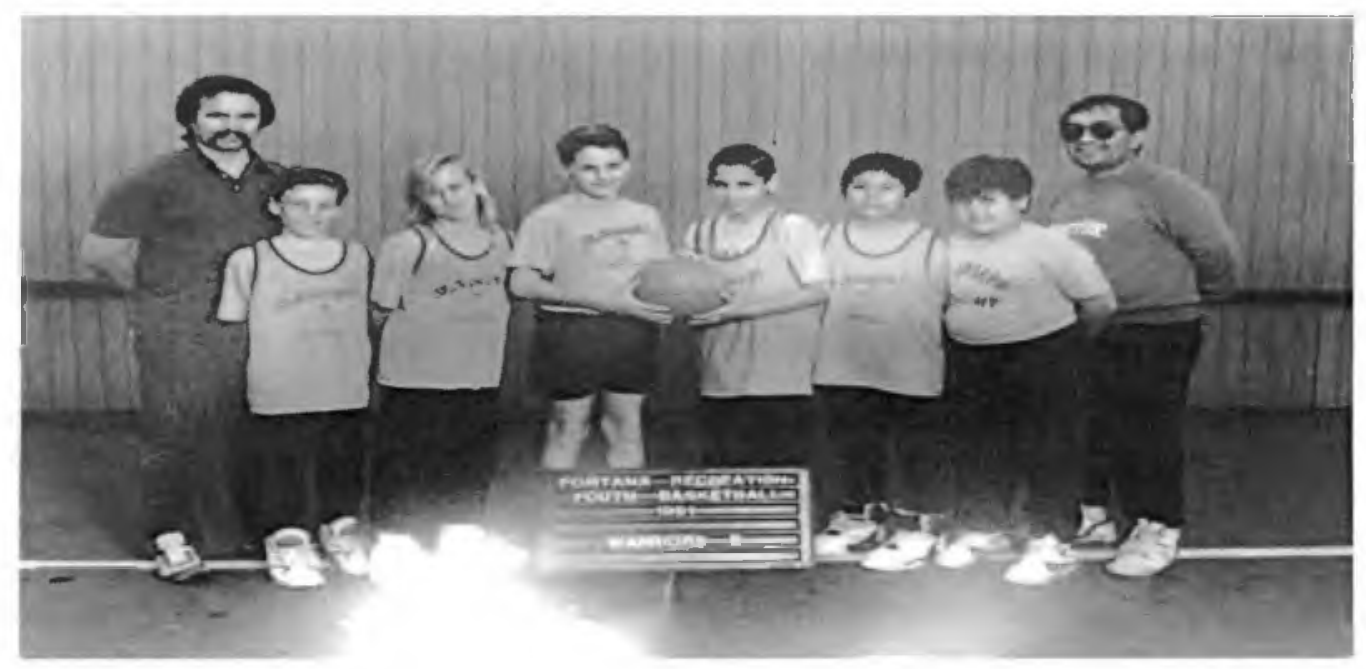

Figure 8: Squinting about cis-heteropatriarchy since 1991

\section{Part II: Welcome to High School}

My first day of high-school, felt more like going to prison than to school; there were bars and barbed wire and unscalable fences surrounding the entire campus - and there were cops swarming everywhere. I was dropped off about a block away from one of the only two outside entrances to the school, where I stood in line behind more than a hundred girls waiting to have our shorts measured and our backpacks searched by campus police—not security or "narks," my high school still has its own fully funded police force.

Later my first day of school, I watched a massive, pink-faced, White male campus police officer break up a fight by grabbing a Mexican girl by the hair and kneeling on a Black girl's back as she cried out in pain and gasped for air. That image, the one of a huge and smirking White cop enacting brute physical violence on small Black and brown 
girls' bodies (while the little White girls stood by and watched with chimichangas in our hands, paralyzed, mouths agape) ...that was an image, and a pile of feelings (terror, helplessness, horror), that would never leave me-or at least they haven't yet.

What the newspapers and school administration called "race-riots" became a regular part of my academic life and were the justification for so many cops on our high school campus. Every day for four years of high school, I watched (safely from the distance of the White, cis, closet) campus police delight in terrorizing students with disabilities, (out) queer students, and students from communities of color.

I learned very quickly the rules for my own survival in high school:

Clique up.

Always change in the stalls, never the locker room.

Be obsessed with boys.

Be obsessed with how you look.

Do your makeup during class.

And wear makeup even while you play sports and your sweat makes it run down your face and burn your eyes.

Never be ugly.

Spend months freaking out about homecoming and prom.

But not about a paper or a test.

Don't wear your brother's t-shirts, even if you iron them. 
Don't ride horses. Or wear boots.

Don't be too smart.

Definitely, don't be gay. (and you're already suspect if you play sports)

In fact, you can play it extra safe by joining in the persecution of people rumored to be gay.

And so, I did.

Not long after I graduated high school, the point guard from my high school basketball team came out to her mom, who shamed and disowned her. That same night, I saw her passed out drunk on the bathroom floor in a gay club called Oasis. The following morning, they found her tiny, Brown body hanging in her closet. At this moment, I thought I could never come out.

To anyone.

Young queers in my community had to hang out (even underage) in clubs ironically named, like Oasis, because those were some of the only relatively safe spaces to be out...and to find community...and to drink and dance away the toxicity and pain wrought by our hateful schools, communities, churches, cultures, and families. Even if just for a few sweaty, alcohol-soaked hours. (I mean, at least the vodka company celebrates you, right?) 


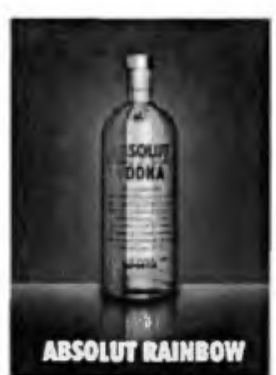

Figure 9: Absolut Rainbow

Later that year, I started playing basketball at a large California community college and entered into my first intimate relationship with a butch lesbian. After losing one of our first games of pre-season play, when the head coach usually chews the team out for shitty defense or missing free throws, here's what our coach screamed in the parking lot while my teammates, their parents (thankfully not my own), and the other coaches huddled around to listen: "You think we are all stupid, Romagnoli? We all know what you two are up to. Disgusting. You think we don't all know exactly what you are and why you try to hide it? Fucking faggots." We climbed into a silent van that reeked of gym bags and still-perspiring bodies and rode home, tears streaming down our cheeks. That old head coach, who is still an academic counselor at the college, verbally and psychologically abused me (and other femxle coaches and players) daily for three full years.

After surviving the closet in community college, I earned what 1 went for: I earned a full ride to a local Baptist University. I took that scholarship, my only offer, and moved into Baptist University's campus apartments with my girlfriend, who played softball at the university. The student handbook at this university (still) requires that 
"students respect the religious traditions, values and ethics of the university"; although, unlike many other Christian universities, they do not require students to be professing Christians. So, I was off the hook there (I was a self-loathing Catholic at the time); however, a part of the university's "statement of faith" titled, "The Christian and Social Order," crystallizes the university's policy on heterosexism: "In the spirit of Christ, Christians should oppose racism, every form of greed, selfishness, and vice, and all forms of sexual immorality, including adultery, homosexuality, and pornography," (University Baptist Faith and Message, 2013). While I was a student, the university policed the students' sexuality by enforcing an unofficial policy known as "the three strikes rule". On the first rumor that a student is gay, the student has to agree to attend counseling on campus. On the second rumor, the student is kicked out of their classes for the semester and must attend spiritual counseling off campus. On the third rumor, the student is expelled without hope of being reinstated.

These official and unofficial policies created a toxic environment, where students would try "catch" other students being gay. I was expelled my second semester (for different and related reasons), not long after being "caught" and reported to administration for the first time by my own roommates. Even more terrifying, the policy actually cultivated violence against queer students. The men's basketball team, once they found out I was gay, would lurk outside my bedroom window whispering ddyyyykkkkkeeeeeee..... we know' you're a dyke....come let us fix you with some dick... It 
was not long before they broke my window and vandalized my car. They would sit in the front row of my basketball games and whisper or call out "dyke" when I ran by them or was shooting a free-throw, often holding up their hands making symbols of triangles. They would flinch at me as if they were going to punch me, or grab their crotch, when I would pass them in the halls, often on our way to mandatory classes like "Intro to Old Testament". I spent my two years at this university living in absolute, daily terror that I was too afraid to tell anyone about for fear of what their response might be: well, aren't you a dyke? Don't be one if you don't want people to treat you like one. Even today, the targeted application of official and unofficial education policy is something I deal with on a regular basis as a queer faculty member at a California community college.

For my entire life in education, like many other queers, I have been brutalized by students, faculty, curriculum, coaches, policy, and administrators. By the time I graduated with a BA, and was still standing over that (still-olive green) sink in my parents' bathroom thinking about ways to end my life, I felt like there was such a hole in who I was as a queer person, that I could only fill it up with books-more and different books than my early education had given me. So, I went back to school again and again and again...and it was critical that I returned to the CSUs; in fact, the CSUs saved my life.

\section{Final Part: Grad School}

It was not until my third master's degree that I finally got to study queer writing and queer thinking and queer identity and queer politics and queer power-with queer 
professors. This was identity crack for someone that had been fiending their entire life-I was absolutely, momentarily, high on what felt like my very first taste of freedom. I immediately became the grad coordinator of the Pride Center on campus, marched on Washington, and came out in the local newspaper just in time for Prop 8 (California's gay marriage ban) to pass and obliterate the dreams, and closets, and families of so many queers. We walked around our campus and community with triggered shame and shattered hearts knowing that (in some places more than) $70 \%$ of our county voted against policy that would allow us access to the rights, protections, and benefits guaranteed by marriage.

$70 \%$.

To have an actual number is such a fucked-up thing because, then you do the math.

You do that math in every classroom, every restaurant, every grocery store, every bar, every mall every coffee shop, every mall, and you even do the math in your own family 
and on your street or in your apartment complex - and somewhere in the pit of your stomach, you realize that not everybody that voted against our rights could have had one of those yellow signs in their front yard or plastered on the bumper of their minivan.

It was our family.

It was our neighbors.

It was our teachers.

It was our students.

It was crushing.

During that moment, being a student at a Cal State both sustained, and transformed, my life and continues to shape my research and my professional life as a public educator in these even more terrifying times. It is was no accident that I started my career as a freeway flying adjunct at the community college I attended, and then eventually hustled my way to a tenure-track gig as close as possible to the queer mecca: San Francisco. These are the seeds that sprouted this dissertation grounded in the intersections of my queer and academic identities.

Now, at thirty-seven, although much more critical of marriage as a hierarchizing social institution that reproduces dominant modes of normalcy and power, I am still/again a tender queer student seeking safety and hope in the embrace of public higher education during a time of increasing hostility and aggression toward the queer community. 
Even after three master's degrees and making it to the last stretch of writing this dissertation, I'm still conditioned to jamming my identity into the confines of the academy to preserve my safety. Even though I have a program and a dissertation committee that fully support my ideas and identity in all of their anarcho-queerness, I still find myself being haunted by that same barrage of questions:

are you sure people will care about this?

are you sure you shouldn't take a more traditional approach?

are you sure you don't sound too angry/emotional/ ? are you sure you will be able to convince people that this work is... that you have something to say that is... that you are... ...valuable?

See, all of my own ancient and internalized damage seeps out through these cracks in my academic security. I still need someone I respect and admire to remind me my story is worth telling, or I will default to my own invisibilization because of my long history of being invisibilized - particularly in spaces of education. It took me far too long in this program to realize that I could, and should, design my dissertation from a queer framework and be explicit about my queer identity and experiences, especially as they pertain to education and prison settings - not just because I deserve to bring my whole 
self to my research, but because those pieces of me add immeasurable value to my research.

\section{Becoming Roam}

Only recently, after more than thirty years as a student, a teacher finally said to me a series of words I didn't know I desperately needed to hear: "Roam," Dr. Henderson said, “I don't have much experience with transgender people or politics, but I want to learn. I want you to know that I see you, and that I want to see you how you want to be seen. The things you are thinking and writing about are so valuable, and so important."

This means I was a student for 30 years before ever feeling truly seen by one of my teachers.

This visibility a gift.

It is a gift I feel lucky to have survived long enough to receive, and it's a gift I pay forward to my own community college students every day.

This is also gift that many members of my family, my community, my colleagues, and even many of my friends and partners over the years, have been unable to give me.

Part of this, of course, is also about my own ability and readiness to accept it.

Because even to this day, every time I visit my parents' house.

I can still see my tiny or teenage or twenty-something self-standing at that still fucking olive-green sink, 
squinting with tears streaming down my face...

and it's all I can do to not look too closely.

Going too far down that rabbit-hole can be deadly.

Reading the comments section online or experiencing micro/aggressions or homophobic acts on campus and in public can often reproduce this same feeling of being small and terrified standing at the sink, even though I'm not tiny anymore, at least not on the outside.

I mean...I'm 6'1, I say and wear what I want, have a pretty fly mohawk, and I changed my legal name to Roam...

but that's all external.

Thankfully, my sweetheart, who

affectionately started calling me "tiny" many years ago, knitted me these tiny, pink, fuzzy, bunnies as a reminder for me to always be tender to that little tiny kid still that is still very much alive in what I think of as this grown-ass queer body.

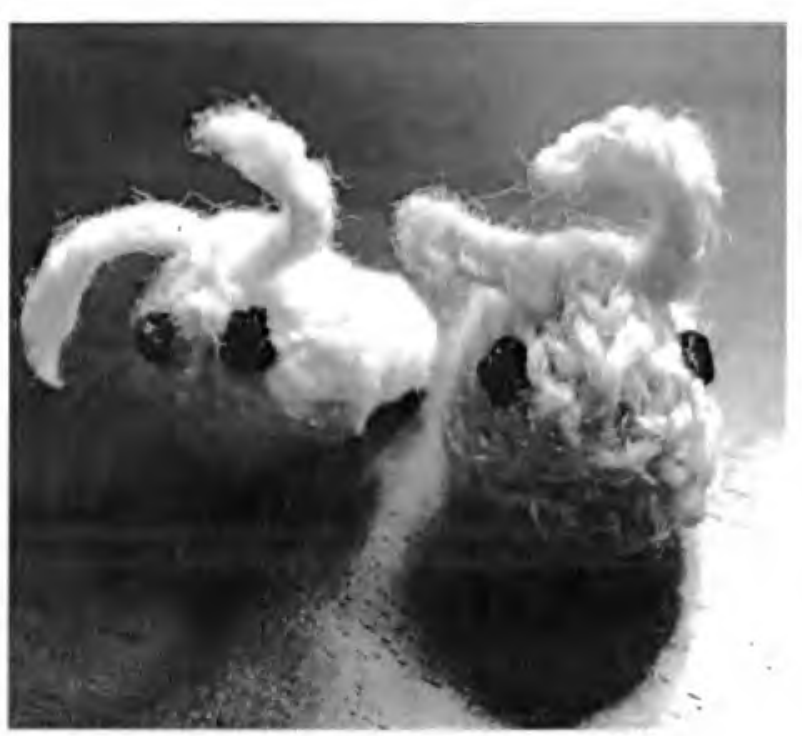

This dissertation is an act of tenderness for that tiny kid still living inside of me... and an act of tenderness for all of the rest of the scholars in my life who I know carry around tiny versions of themselves and continue to suffer so much pain at the hands 
of education, yet who have still committed their lives to transforming these spaces. In 2018, schools are still not spaces where all types of womxn, particularly Black and Brown and queer womxn, can thrive; in fact, we continue to face predatory social and disciplinary practices that push us out of educational spaces. Even though some of us (particularly those of us with White privilege and/or who can pass) make it, we have a great deal of work to do to revolutionize our p-12 systems; in the meantime, it is our responsibility to provide quality higher education to the incarcerated womxn and queers that have been funneled out of our schools and into jails and prisons. This is how I came to teach in jails and prisons, which is the focus of the next chapter: a self-study grounded in my experiences as a queer educator in a carceral facility. 


\section{Chapter Three}

This is a self-study centered on my experiences teaching and working to build a transfer-pathway in a county jail. I am a full-time English professor at a community college in Northern West Coast California. As the result of a 2015 Senate Bill, my community college, along with 18 other California Community Colleges, is cultivating a partnership with CDCR (California Department of Corrections and Rehabilitation) to provide education programming in jails and prisons. Each week, in addition to my full campus load in the English Department, I taught three GED-prep classes at the county jail, which sits less than a mile away from our campus. At the jail, I had one class that meets on Tuesdays and Thursdays in the "main classroom" with the PC (protective custody) men. PC means that these men are in jeopardy of being hurt by other prisoners for various reasons. On Mondays, I teach in the mods (living modules)-these classes are for students whose classification does not permit them to leave their living quarters. The jail is deliberately confusing and unmarked, so after more than a year, I am still unsure of how many mods there actually are in the jail.

I teach in both $\mathrm{D}$ and $\mathrm{H}$ mods, which each house around 30-50 male prisoners. I think that it is important to note that I made it clear to my college and to the program deputies at the jail that I would prefer to teach womxn. On my first day, when they told me I would be teaching men (and specifically wanted to know if I was comfortable teaching PC males), 1 told them I was fine with that for this semester. but that in the 
future, I'd prefer to work with womxn as I had previously requested. The program deputy, who was also a womxn, replied, "Oh, God. Why would you ever want to work with them? They're so nnneeeeeeedddy and annoying." I was uncomfortable and horrified, and too afraid of losing my new job to push it, so I just laughed it off with her. Being afraid to push things for fear of losing access to incarcerated students is an experience that I share with many of my prison higher ed colleagues. I keep thinking about the gravity of what it means that all of these womxn are in cages being mocked by other womxn for their emotional and psychological needs. It's still distressing to think about. To date, I've still not been allowed to teach the womxn because, the deputies say, the men respond so well to me. I take this to mean that because I'm a masculinepresenting, gender-queer lesbian, they don't have to worry about any inappropriate thoughts or contact taking place in my classroom so long as it is filled with men; that situation might be different if I were allowed to teach the womxn.

The first vignette illustrates my experiences teaching the "PC Males" in a jail classroom, and the last two vignettes depict typical days in D and H mods. My goal was to write the vignettes in a way that brings the reader into the psychological and emotional dimensions of being a White queer person teaching in a carceral setting. Following the vignettes, I discuss some of the most critical themes that have surfaced in my own personal experiences as a queer higher educator working over the last several years to 
expand incarcerated students' access to upper-division coursework, especially for incarcerated womxn and queers.

\section{Experiential Vignettes: Teaching in Jail}

\#1: Tuesdays and Thursdays Teaching PC Males in the Jail's Main

\section{Classroom}

Arrive in the Sheriff's station parking lot twenty minutes before twenty minutes before class, knots in stomach.

Calm your racing heart.

Deep breaths.

Empty your pockets.

Hide your cash under the seat of your car.

Remove your car keys from the clicker and hide the keys under the floor mat.

Bury the clicker in your deepest pocket.

Count your pens.

Count your markers.

Consider what you are wearing.

Take off that hoodie.

Maybe your watch, too.

Check your teaching supplies for contraband (staples and paperclips).

Double-check your teaching supplies for contraband (texts and ideas). 
Put your teaching supplies in a small stack.

Hide your cell phone under the seat.

Hide your backpack under your hoodie.

Find your ID.

Re-count your pens and markers.

Get out of the car.

Double check you have your ID.

Re-count your pens and markers.

Re-consider your attire.

Double-check your pockets are free of contraband.

Triple-check you have your ID.

Lock your car.

Walk to the lobby.

Greet the homeless people that live (and are often forced to shit) in the entryway to the lobby of the jail. 


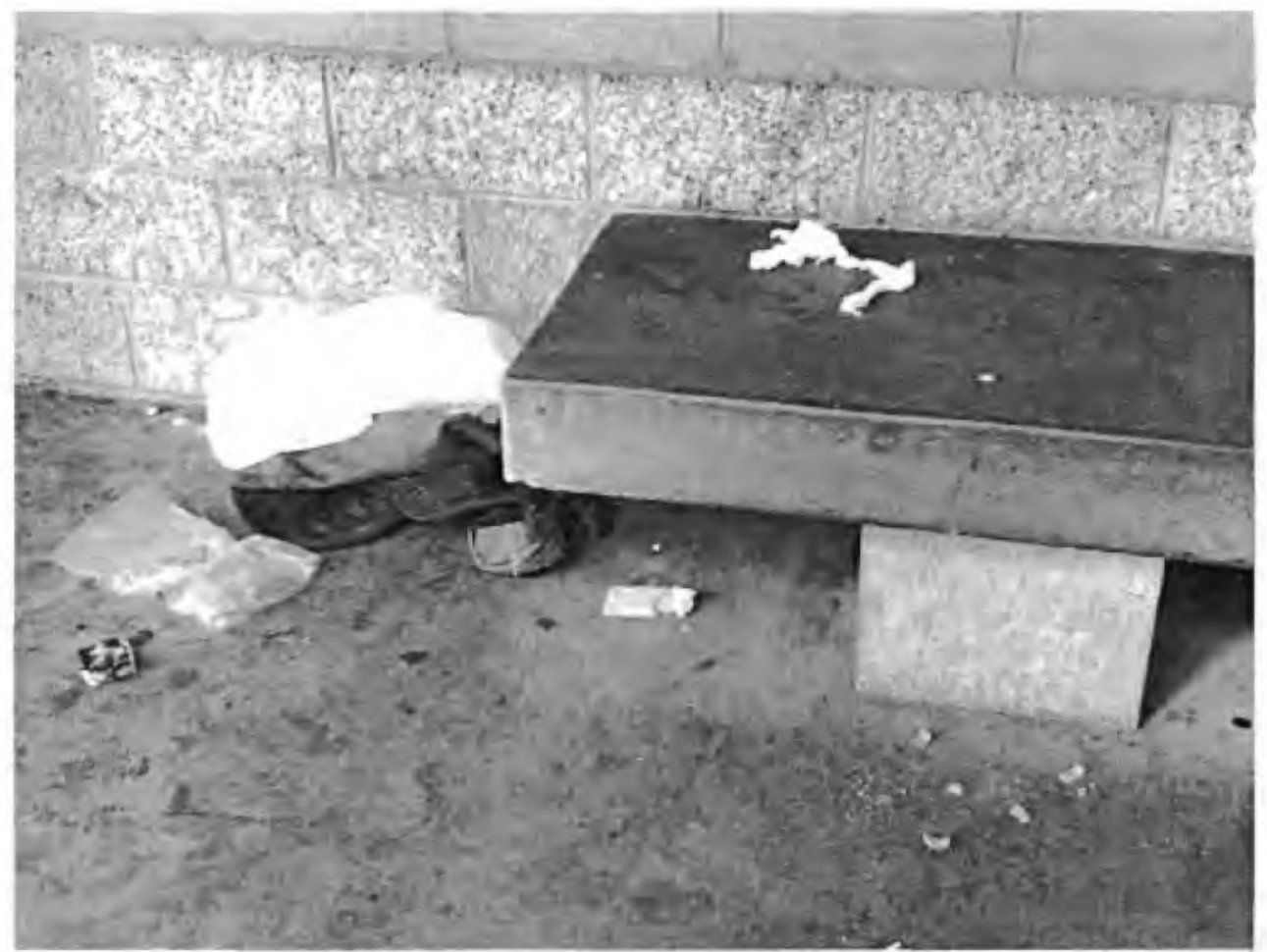

Figure 10: Entryway of jail lobby.

Enter the lobby.

Get ignored by corrections staff behind the bullet proof glass.

Wait alone until someone decides to acknowledge you're standing there, or wait behind the flood of attorneys that might be in line to get in for visits.

Get called "sir" by corrections staff (even though they see you every week).

Get micro-aggressed by corrections staff when you hand over your passport:

You look so much prettier with long hair!

Sign-in.

Get "Visitor"s Pass" lanyard.

Get buzzed through the first gate. 
Walk through metal detectors.

Turn left.

Press button to call "Central Command" and be buzzed-in to the larger facility. Show Visitor's Pass to camera.

Wait

Wait

Wait

Wonder if they are just messing with you (because you've been warned they sometimes do), or if you need to press the button to call again.

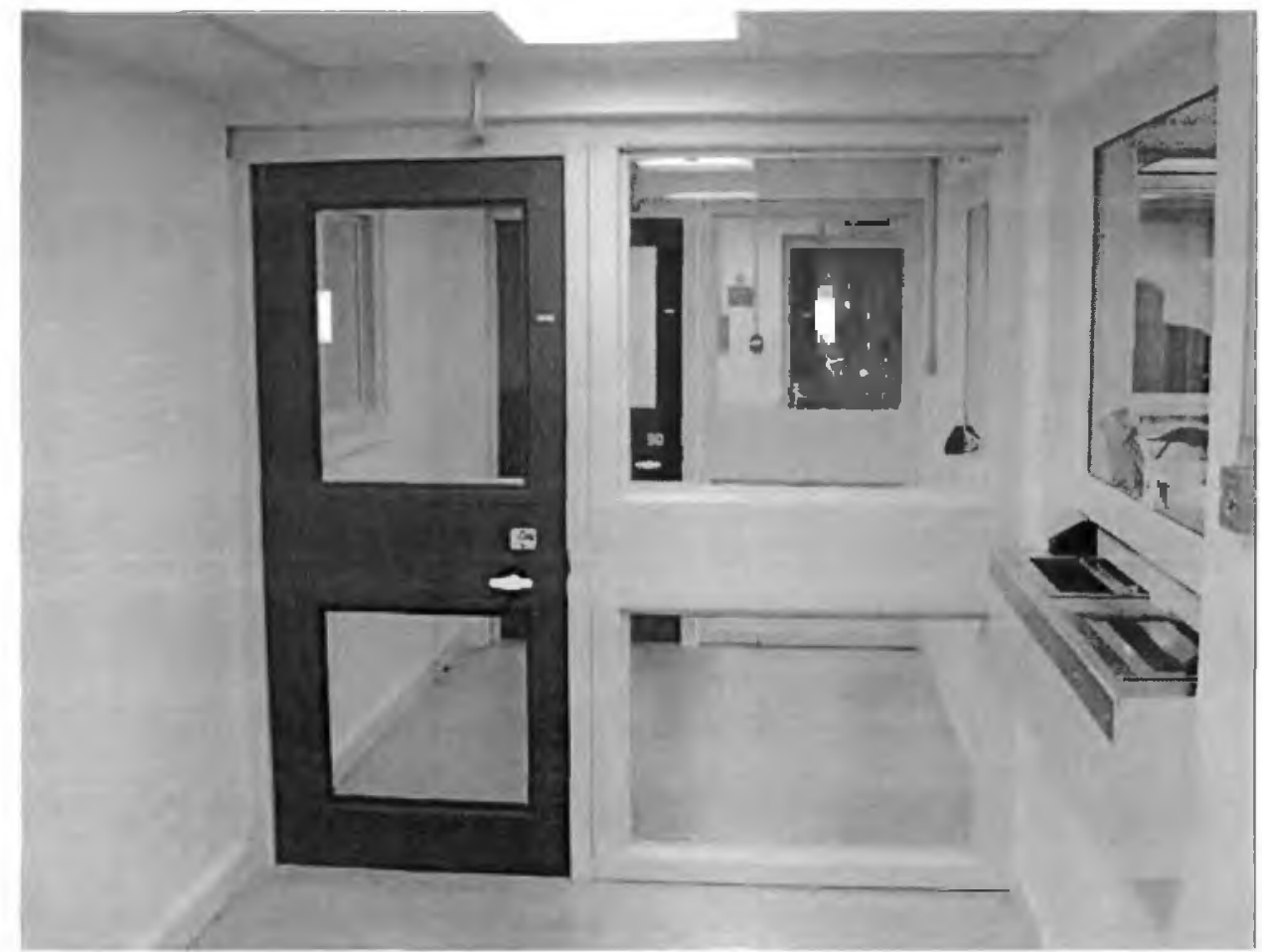

Figure 11: Entryway of central command.

BUUUZZZZZZ 
Enter holding room

Stand in small space between security doors

SLAM (door behind you)

Show Visitor's Pass to camera.

Wait

Wait

Wait

BUUUZZZZZZZ

Open the door in front of you.

Turn right.

Walk down unmarked hall.

Pass the femxle prisoners working in the kitchen.

Find one of three unmarked elevators in first unmarked hall.

Press button to call for elevator and wonder if it will come because the lights on the elevator, by design, don't work.

Wait.

Wait.

Wait.

Cops passing.

New prisoners screaming 
being searched,

detoxing,

flip-flops flying in the hallway.

Keep your eyes down

and don't make eye contact,

or they will talk shit to you

What the fuck are you looking at, dyke!

I might be in here, but you're still the abomination, bitch!

STILL waiting

Elevator doors (finally) open.

8 White, male cops already in the elevator.

Shit.

Stomach sinks, remembering the time the belligerent hick ran in to that gay bar with a baseball bat screaming, "fucking homos," breaking a bunch of bottles and threatening to break bones, and when the queers called the cops, the cops showed up and harassed the queers.

That was the first time I saw a billy club used on a drag queen.

But it wasn't the first time, or the last time,

I learned to not trust cops.

Still, I get in that elevator packed with cops. 
Sweating.

Heart, racing.

I watch them delight in my anxiety and hesitation.

Smirking red faces topped by shiny bald heads or bright white hair.

Blue eyes twinkling.

Step into the lion's den, Roam...

into silence and terror and discomfort and hatred.

Seconds pass like decades.

Until I step out on the second floor,

then laughter and chatter resume behind me when I exit.

Turn right.

Walk down another unmarked hall.

Breathe.

Recover.

Pass the male inmates working in the laundry.

Enter "Inmate Programs" wing.

Turn left.

Sign out the panic button.

Put the panic button in your pocket. 
More knots in stomach—Will you need it? Set it off by mistake? Accidentally forget to return it?

Check-in with program deputies.

Pick-up roster of today's students.

Walk down the hall to the classroom.

Pass the computers that the students aren't allowed to use.

Re-arrange the tables from huge separate rows to a single, large square.

Get pencils and loose-leaf out of the supply closet.

Rehearse the request in your mind.

Use classroom phone to call central command.

Stumble through request to have an officer bring your students.

Um er, I teach English. Can someone bring students to classroom er...umm ....Main Classroom?

Wait.

Sometimes 15 minutes.

Sometimes 50 minutes.

Officer arrives with students.

Students sign-in.

Officer leaves.

Sigh of relief: 
Finally,

I get to teach.

Just me and the students and the materials.

(And probably some cameras, and always some officers listening at the doors)

In a blink, class, too soon, comes to an end.

Rehearse request.

Call central command.

Stumble through request to have an officer pick up students at the end of class.

Enjoy final moments of chatter with students.

Officer arrives promptly.

(unless there's a lockdown, or you've offended the officer in central, in which case, it can take an hour or more)

Students line up.

This is the worst, most dehumanizing moment of the day.

The scholars I was just sitting around a table and talking about books with are jolted back to being prisoners. They are told to line-up and take off their shoes, so that they can be searched before being returned to their cells.

I hate this part.

Probably not as much as they do, but I've never asked them because I feel too ashamed to even acknowledge I know it happens. I usually turn my back and too-slowly 
erase the board and pack up my materials. This process dehumanizes all of us; even the officers, Freire might argue. How intrusive, humiliating, and demeaning this process is varies by officer. Sometimes the officer takes my students out into the hallway and searches them as discreetly and as painlessly as possible. In my experience, this is how the femxle guards approach this process, often joking with the prisoners and chatting with them during the search. The male officers, on the other hand, tend to delight in making a public display of shit-talking my students while searching them right there in our classroom - almost joyful to be the one to remind prisoners that they are criminals, after all. I feel that some of this is "normal" in terms of how officers treat prisoners, and that some of it is to remind me of my place, too. Sometimes the officer will look repeatedly at me to see if I'm watching while he searches my students, smiling and nodding if our eyes chance to meet...as if we are in collusion. I feel repulsed by the officer and disgusted with my own lack of power to defend the humanity of my students in these moments.

Breathe.

Recover from this process.

Copy Roster.

Return roster to Inmate Programs Office.

Return panic alarm (except for that one time you forgot and made it all the way to your car, only to have to repeat the entire entry process to return it... making you late to your next class on campus). 
Knots in stomach.

Navigate back through blank hallways filled with hateful faces

(or at least faces you perceive or fear to be hateful)

Sign back out.

Receive one more annoying/condescending comment about your students or about your hair

from officer in the lobby

Finally, out.

Fresh Air.

Sun.

Birds.

A final sinking feeling in my stomach with the realization that while I drive away draped in the comfort of my Prius and my privilege, the students I just left will stay in cages, not getting any fresh air or sun or birds any time soon.

That's on Tuesdays and Thursdays, which are pretty simple because I'm only teaching one class in an actual classroom. The students come to me, and we have desks and supplies and a white board. Mondays in D and $\mathrm{H}$ mods are a MUCH different story. 


\section{\#2: Mondays in $\mathrm{D}$ and $\mathrm{H}$}

\section{D-Mod.}

On Mondays, I teach a one-hour class in two different mods (modules), which are the prisoners' living quarters. No sunlight makes it into the mod-these prisoners are buried deep in the belly of the jail. Depending on the classification of the mod (the higher the prisoners' classification, the deeper in the belly their mod is located), some of the prisoners might never be allowed to leave the mod-not even for meals, visits, or programs like anger management or AA. This is the case for both of the mods I teach in on Mondays: other than corrections officers and religious practitioners, I am the only other visitor with access to these men. Each module has a "yard", which is a $10 \mathrm{ft}$ by $15 \mathrm{ft}$ square with four cement walls and a tightly woven chain link ceiling-although it opens up to the 'sky', virtually no sky is visible since this wing sits in the middle of the carceral complex and is surrounded by taller wings of the building. All prisoners can see is jail. Ever. 


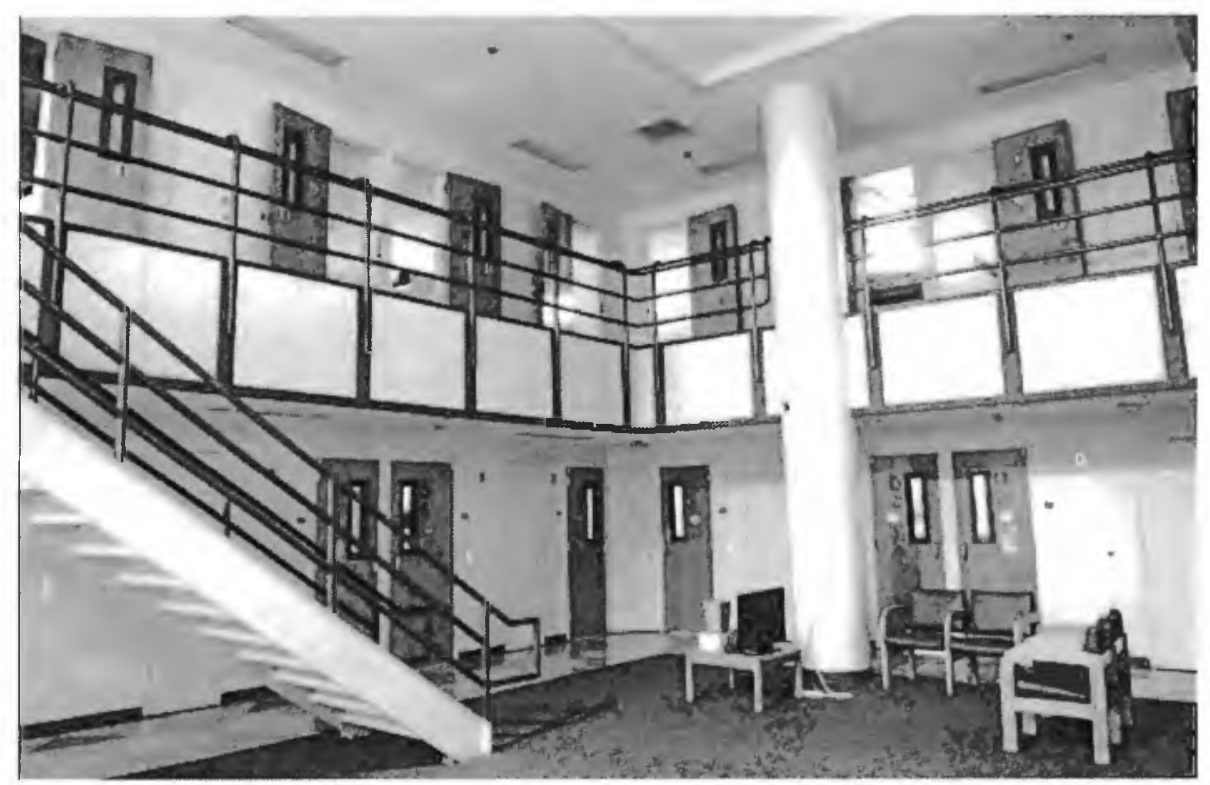

Figure 12: D-Mod.

There can be anywhere from 20-50 prisoners held in each module, and in the center of each mod sits the officer assigned to that mod for their shift. The attitude of this officer dictates the entire mood of the mod, which can have a huge impact on my class. There is a fair amount of consistency in which guards are assigned to the different mods on certain days of the week. Usually in D-mod, the officer on shift during my class is a lesbian and the vibe is good. When I arrive, she is standing at her panoptical post joking around with prisoners who might be lingering around her station just to chat affectionately with her, while the other prisoners are walking around the mod freely with surprisingly light hearts for such a dark space--sometimes the prisoners are roughhousing and laughing like brothers might. It is almost as if they are sharing a (disgusting) dorm or hospital wing: there's a tv or two on in the background; there's 
racks of awful books like Chicken Soup for the Inmate's Soul (the only book a prisoner is allowed to take to their cell) and bibles strewn about; and prisoners cruise around in slippers playing games on Edovo "education tablets" that look like foam iPads for babies, while carrying around huge plastic cups filled with various brightly colored liquid concoctions they purchase at "commissary."

The lesbian officer has an easy way with the prisoners. This is not the case with the male officer, who is typically on shift in the H-mod during my next class. Prisoners clearly respect —even enjoy - the lesbian officer, and she allows the non-students to stay out of their cells while our class takes place. She might even help me set up a table in the middle of the mod, where individuals not enrolled can still listen-in while I hold class. More common than that is for a prisoner that is NOT a student to help me set up a table and chairs, using the opportunity to chat with me about how they, too, might enroll in classes through the JC. Once we have a table and chairs set, the officer uses the roster to call my students to class over the PA. This set-up process can take anywhere from 5-25 minutes of my class time, which is only one hour per week with each workshop (the college called them "workshops", because they are not real courses). I finally find myself sitting at a table with anywhere from three to twelve students (it's different every week), and we do our best to become an island in the middle of the incessant goings-on in the mod-like commissary. 
Commissary is essentially a pop-up shop where prisoners are able to pick up orders of food and other supplies (greeting cards, tampons, shower slippers) they placed the week before; unfortunately, commissary happens every Monday morning...right in the middle of my class. Commissary is a HUGE deal in the mods, especially in those mods where prisoners don't get to leave. In California, we have three levels of classification:

A (full rights to commissary, visits, phone calls) .

B (full commissary, limited access to visits and phone calls)

C ( $1 / 2$ commissary, no phone calls, one visit per month—one step above solitary).

Both of the mods I teach in are C-classified, so commissary days are especially hectic since prisoners' access to commissary can be limited by half. Each Monday, two guards come in with several boxes filled with the commissary orders like soap, ramen, power bars, shower slippers, and greeting cards. If a prisoner misses commissary because they are in my class, they don't get their order. This means most of my students are unable to focus on my class, since they have to be hypervigilant in listening for their name to be called to pick up their commissary. Every few minutes, a student gets up to pick up their overpriced box of awful food (ramen and chips, mostly) and useless soap, and take it up to their cell before returning back to class. This is pure pandemonium. Every week.

Once 1 wrap up class in D-mod, I begin a new terrifying journey to the elusive H-mod...I use the word "elusive" with deliberation, as I've had many officers and jail 
instructors alike theorizing, exoticizing, and misconstruing what it must be like to teach those types of criminals.

- She wouldn't be laughing if she knew who was really sitting next to her at that table-(White, cis-male, Officer).

- These are the most sophisticated criminals...their manipulation of you will be more subversive than that of your students from the other mods-(White, lesbian, Sergeant).

- I can't believe they are letting you in H-mod! That's basically like the holy grail...some of us have been dddyyiiinnng to get in there to see what those guys are like-(White, middle-aged, cis femxle GED Math Instructor).

\section{H-Mod.}

Next-level anxiety.

The $\mathrm{H}$ mod requires another long trek down multiple unmarked halls.

A ride back down to the first floor in the elevator without lights.

Then a walk down the first unmarked hall with the holding cells for folx waiting to be booked

Madness

Screaming

Detoxing 
HELP ME HELP ME HELP ME HELP ME HELP ME HELP ME HELP ME HELP ME HELP ME HELP ME HELP ME HELP ME HELP ME HELP ME HELP ME HELP ME HELP ME HELP ME HELP ME HELP ME HELP ME HELP ME HELP ME HELP ME HELP ME HELP ME HELP ME HELP ME

One day a womxn was screaming when I went to my first class, and was still screaming two hours later when I left my second class - the sound of her shrieking dominated my psyche for weeks.

After passing the ghosts leering from the holding cells,

I walk down the next (visibly) endless and unmarked winding hall with no windows or doors for what feels like eternity ( 3 minutes, to be exact).

Finally you reach the hidden, unmarked elevator.

This one goes to the other, secret, second floor

Where they house the prisoners classified as most dangerous.

These are my students.

I arrive at the impossibly heavy metal and glass door and

Press the button to call central.

Hold out ID for camera

BBBUUUUUUZZZZZZ

Open the first door.

SLAM (first door closes behind me) 
Wait. wait. Wait.

sometimes seconds.

Sometimes minutes.

Watching the men inside.

Eating.

Silent.

Gazing.

(not) watching TV.

Finally.

BUUUZZZZZ.

Open the second door.

WOMXN ON THE MOD!

The guard announces when I walk in.

There are men walking around only wearing tiny towels around their waists after showering.

They moan and groan when I arrive for class.

Sometimes the officer will scream

over the loudspeaker

"GET BACK IN YOUR CELLS" 
"EVERYONE WILL REMAIN ON LOCK DOWN WHILE THE JC CLASS

TAKES PLACE."

“THOSE OF YOU ENROLLED IN THE CLASS, IF YOU WANT TO GO, COME OUT WHEN I POP YOUR DOOR. IF YOU DON'T WANT TO GO TO

CLASS, DON'T!"'

It really depends on the officer.

Sometimes I walk in and the officer ignores me entirely.

Or, sometimes, I hold class in the middle of the mod with the officer leering at me and my students from his perch.

Or we might be locked in a tiny storage closet covered in black mold that the students are sometimes able to set-up into a makeshift classroom depending on the attitude of the officer on duty and the number of students in the class that day. I've been crammed so tightly in a storage closet with 9 men, that none of us had room to stand up.

Behind the officer in command, there is often an Aryan brother running tiny laps in that $10 \mathrm{ftX} 12 \mathrm{ft}$ cage ( 4 cement walls with a chain link ceiling) they call "the yard".

Tiny furious lap after tiny furious lap after tiny furious lap after tiny furious lap... His body is bursting with rage and throbbing and pink

Iron Cross or 88 tattoos glistening with sweat.

Scowling. 
Sometimes, for the entire hour of our class, we (try not to) watch this go on.

Class starts.

Commissary starts.

And in a blink, class ends, and I'm headed right back out of the belly and toward the sun.

Before I leave either of the mods, if the prisoners are not locked-down in their cells, they swarm me on my way to the door. The vast majority of them want access to my classes in the jail or information about applying to the JC before they are released, so that they might start right away when they get out. As I mentioned, I might only have 3 enrolled students sitting at the table with me while 30 frustrated (or straight-up pissed) faces might be peeking out of tiny cell windows as they watch us hold class while they are locked-down. Sometimes the prisoners that are locked in their cells will yell at us and try to distract the students for the entire time we are together. There is deep tension wrapped up in this dynamic. It creates an upper and under class of prisoner, and it often makes the students a target for harassment from other prisoners and from the officers who beleaguer my students constantly: "Who do you think you are? You ain't no student. When you get out, you're coming right back. You're my job security." When I leave, it often feels like the men, those that are my students and many times those that are not even my students, are throwing themselves around my legs with all their weight and begging me to stay-to bear witness. 
To bring warmth.

To see them; to see the officers.

\section{Analysis of Themes: Navigating Identity, Trauma, and Curriculum}

I enter the jail environment a genderqueer lesbian with myriad forms of privilege including (not limited to) White, education, economic, and able-bodied privileges. These aspects of my identity shape the experiences that $I$ have as a college instructor in a carceral facility, and they inform the meaning I make from these experiences. My hope is that the experiential vignettes provide a window into the stress, anxiety, fear, and tedium of teaching inside a correctional facility. The following section delineates the most important themes that have surfaced as I've worked in this context, which include navigating identity, navigating trauma, and navigating curriculum in carceral settings.

\section{Navigating Identity: Gender, Sexuality, and Whiteness Inside Correctional}

\section{Facilities}

Every day that I teach in the jail, I walk down the hallway with the "holding tanks." I pass by these individuals in tiny cement rooms who have just been arrested and are often highly intoxicated or are detoxing. Many of them are screaming or crying or looking desperately out of the tiny window in the door that allows our eyes to meet if I make the mistake of looking anywhere but the floor:

Come let me give you some dick, dyke!

What the fuck are you looking at, dyke bitch? 
Like my Whiteness, my genderqueerness and sexuality are parts of my identity that I cannot leave at the gate. These identities, and my experiences belonging to communities targeted and brutalized by the police, impact every interaction I have with students and with correctional staff. Even on days where nobody directly calls me a White bitch or a dyke, White supremacy, misogyny, and homophobia are still pervasive-it's the water we are swimming in whenever we enter a correctional facility, in that it's how the power, as well as the spaces, are organized.

One of the most uncomfortable situations I had to navigate as a new teacher in a correctional facility was the Prison Rape Elimination Act (PREA) training; this is a federally mandated (signed into law by George W. Bush in 2003) training that every individual that volunteers or works in a prison or jail must complete. Although every correctional facility has to offer this training, how it actually happens varies not only by facility, but also by officer conducting the training. This legislation was designed in response to myriad studies dating back to the 1970 's that demonstrated the prevalence of rape in US prisons. It is important to note, that the prison rape crisis and the associated health risks we experience on this continent are uniquely American. Other countries have eliminated prison rape altogether by enacting policy and practices aimed at securing, not denying, prisoners' safe access to sexual intimacy. Variations of this type of policy include access to conjugal visits and even open prisons for certain types of offenders (meaning prisoners are allotted periods of time to visit home). Some places even provide 
access to condoms for prisoners - a practice considered illegal in California.

Additionally, many states like California and New York, build prisons in remote areas that make any visitors at all, much less conjugal visitors, difficult and unlikely. Needless to say, the PREA PowerPoint has done nothing in the way of eliminating the crisis of prison rape.

To date, PREA is the only "training" I've received for teaching in a correctional environment. Two weeks after I started teaching at the jail, the Inmate Programs Officer cancelled one of my classes to sit me down at her desk and complete the PREA training. I had not met her prior to that moment, and she was immediately too-friendly...as if she were sure we shared some secret politics. She closed her office door behind us and began to load up the PowerPoint on her desktop. Although the presentation had about 30 slides, she said there were only two she wanted to discuss with me. She could hardly contain her excitement when she pulled up the first slide with the images of shanks that prisoners (not at this facility, she clarified) had constructed out of goods like toothbrushes, tissue paper, coffee grounds, and spoons. It was almost with glee that the officer warned me about paperclips and staples and the sophistication with which prisoners will fashion weapons, which, she said, would surely then be used to harm officers or myself. Once the weapons portion of the training was over, she moved on to the actual PREA slide.

At this moment in the training, I was expecting to talk about preventing prison rape. but that never happened. My trainer began by telling me to NEVER touch my 
students (she refers to them as inmates), then my jaw dropped to the floor when she began to rattle off a list of behaviors that I was to report immediately should they take place in my classroom. She told me I would be fired for touching any prisoner, or for failing to report my students (or any other prisoner) displaying any of the behaviors on her list. Essentially, she instructed me to enforce heterosexism by demanding I report any form of intimacy between same-sex prisoners including joking, hugging, and high-fives. The program officer took particular delight, a literal sparkle in her eye, when she added: "It doesn't matter if they are gay or if it's consensual. If I see two womxn being intimate, even if they tell me it's consensual, it's a write-up. That's part of their punishment in here." Just let that settle in for a moment: denying prisoners consensual intimacy and touch is part of their punishment-and the officers take visible pleasure in the punishing. I see officers taking the same delight in cutting prisoners off on the pay phones in the mods, in locking prisoners down in the mods, in searching them in the hallways... and I can't help but wonder every day how any of us (mostly them, since I'm a relative outsider) will ever heal from these experiences. After doing this dissertation work, I'm not sure I ever want to go back to regularly being in a correctional facility-but 1 have the freedom/privilege to choose. I am leaving this work still deeply perplexed by the number of womxn and queers and people of color making a living on, and delighting in. the dehumanization of our own people. 
In addition to the complexities of navigating gender and sexuality, Whiteness is also a constant negotiation with students and with correctional officers. Race cannot be ignored-next to gender, race has the largest impact on how the correctional facility is organized in terms of prisoners and officers alike. We are starting our third semester at the jail, and I can count on one hand the number of times I've seen officers that are people of color. The prisoners in the mods construct a different racial narrative; my first thought when I entered the mods was: oh, this is where this county is hiding all of its Black people. Meanwhile, the community college, which sits less than a mile away from the jail, struggles to recruit and retain Black students. These circumstances of location are not incidental. Interestingly, the students from communities of color pay far less attention to my Whiteness than the White prisoners--in fact, many White students talk about little else but Whiteness. White students are often angry because they, unlike prisoners from other races, are forced to intermingle with people from different races. This means that White students are regularly transferred between cells and mods to meet the needs of the facility; sometimes, they disappear or appear in my classes for just this reason. One new student, the only White student in a class of all Latinx students, told me this was his seventh cell in five months and when I asked why, his response was: "Reverse racism! They can't mix other races, so they move us Whites around whenever and wherever they want." By the next week, this student was gone--transferred to another cell in another $\bmod$. 
It is, of course, impossible to plan effectively for any class when instructors don't know who the students are and whether or not we will ever see them again. Incarcerated White people in jail and prison often feel persecuted for being White, and as a result, are often released back into the community with a deep resentment-even hatred-for minorities that they may not have had prior to their incarceration. I watch these sentiments fester in my classes every day-it was particularly evident when an accused pedophile was stabbed on one of my mods. After that, officers split my class in to two half-hour sessions-one section was the gang dropouts (all POC) and the other section was all violent sex-offenders accused of the sex crimes (pedophilia, elderly rape) considered most reprehensible by other prisoners. Splitting my class made it easy for other students, and the other prisoners on the mod, to identify which men were in for violent sex crimes - the White students - and this effectively made the White students even greater targets. It also provided me with one of the greatest challenges I've had as a teacher...it's much easier to teach students when you don't actually know what they are in for-the knowledge of the crimes these men committed triggered my already deepenough contempt for White men and all of their rape and pillaging, as well as called into question my own values and beliefs about the transformative capacity of individuals and about prison abolition...how should communities treat someone that rapes an old person or a child? 
In addition to sharing concerns about their own race-based mis/treatment, White students also frequently test me to find out the extent to which I uphold White nationalist ideals. To be clear, White people on the outside (like in the grocery store) are doing this far more blatantly these days than at any other point in my lifetime. The (re)proliferation of the Aryan brotherhood is one of the most critical issues we are facing in jails, prisons, schools, and communities. One student that comes to mind got me on the very first day of class when I introduced myself and told students I was originally from Southern California. Leland's big blue eyes in his big, shiny pink bald head lit right up and he says: Oh, you're from So Cal?! I loooooooove So Cal... especially Orange County...you know why I go to Orange County...right??? They got them meetings...You know what meetings I'm talking about... Unfortunately, I do know what he's talking about. He is referring to the now not-so-underground Aryan brotherhood meetings that take place in the overwhelmingly White, wealthy, county of Orange. I went to high school, about thirty minutes east of Orange. My hometown (Fontana, CA) has a deep history with the KKK; Grand Wizard George Pepper and the White Aryan resistance leader, Tom Metzger, established their headquarters in Fontana in the 1980's, and as recently as 1987, had a Klan march right down main street (Sierra Avenue). I feel ashamed to know all too well what Leland is talking about in So Cal. All of these layers of identity (gender, sexuality, race) permeate every interaction between individuals in a correctional facility; they determine the structure of the housing units and types of "jobs" available to prisoners, 
even which prisoners can have caffeinated coffee; and they have direct impacts on the types of curriculum (even which library books) that will be available in the jail. In addition to the complexities of navigating identity, prison and jail higher educators like myself also face challenges related to navigating the direct and vicarious trauma we experience when we agree to work in a correctional facility.

Navigating Trauma: Teaching in the Wounds

Knowing your students leave your classroom to live in a cage affects you.

Leaving your students in the care of people you know see them as animals affects you.

Teaching in a module where a stabbing or suicide happened yesterday affects you. Having a student disappear because they were sent to the hole affects you. Witnessing officers abusing prisoners affects you. Listening to the stories your students tell about their experiences affects you. Your inability to do anything about any of that affects you.

One of the most disturbing things I found through this research is the extent to which people entering carceral spaces are often at best ignoring, and at worst reproducing, unbelievable trauma. Teachers are forced daily to ignore the trauma that our students (and correctional officers) are experiencing, and we are often prohibited from 
bringing in curriculum that correctional officers feel might "trigger unhelpful emotions" in prisoners. To be fair, this is the same excuse many of my White community college English faculty colleagues on campus use to avoid teaching topics that address critical, painful, and uncomfortable (for them) social issues like White supremacy. Teaching inside correctional facilities is like teaching in a festering wound-or teaching in all of America's historical wounds of slavery, anti-Blackness, colonialism, misogyny, homophobia, poverty, ableism, and xenophobia - and being asked to ignore the wounds. In addition to our collective, social wounds, every individual in a jail or prisonincluding teachers and officers, is not only carrying around our own individual trauma, but we are all further traumatized by what we experience while we are inside a correctional facility. Enacting prison higher education in jails and prisons requires tremendous (impossible) capacity to ignore identity-based trauma-this is true for students, for teachers, and for corrections staff. Not only must we ignore the trauma that we all know is happening all around us in these facilities in order to keep our jobs, but we must also ignore our own participation in reproducing that very trauma. No matter how much of a critical pedagogue I fancy myself, at the end of the day, I'm still a White "legal" citizen that gets to climb into the comfort of my Prius and drive to the privacy of my home in the forest. I still (at least pretend to) ignore the disparities I see in access for students with disabilities, ESL students, and queer students, many of whom are kept in solitary "for their own safety." I still stand-by and watch without intervening when I see 
officers, and even college faculty or staff, mistreat incarcerated students. It feels particularly damaging to witness officers (or teachers) from minoritized groups like POC, womxn, and queers, for example, abusing incarcerated students. This dissertation is my attempt to intervene in the perpetuation of that trauma. 
79

Navigating Curriculum as a Trickster Inside: \#JailMail and Gaming the

System

to

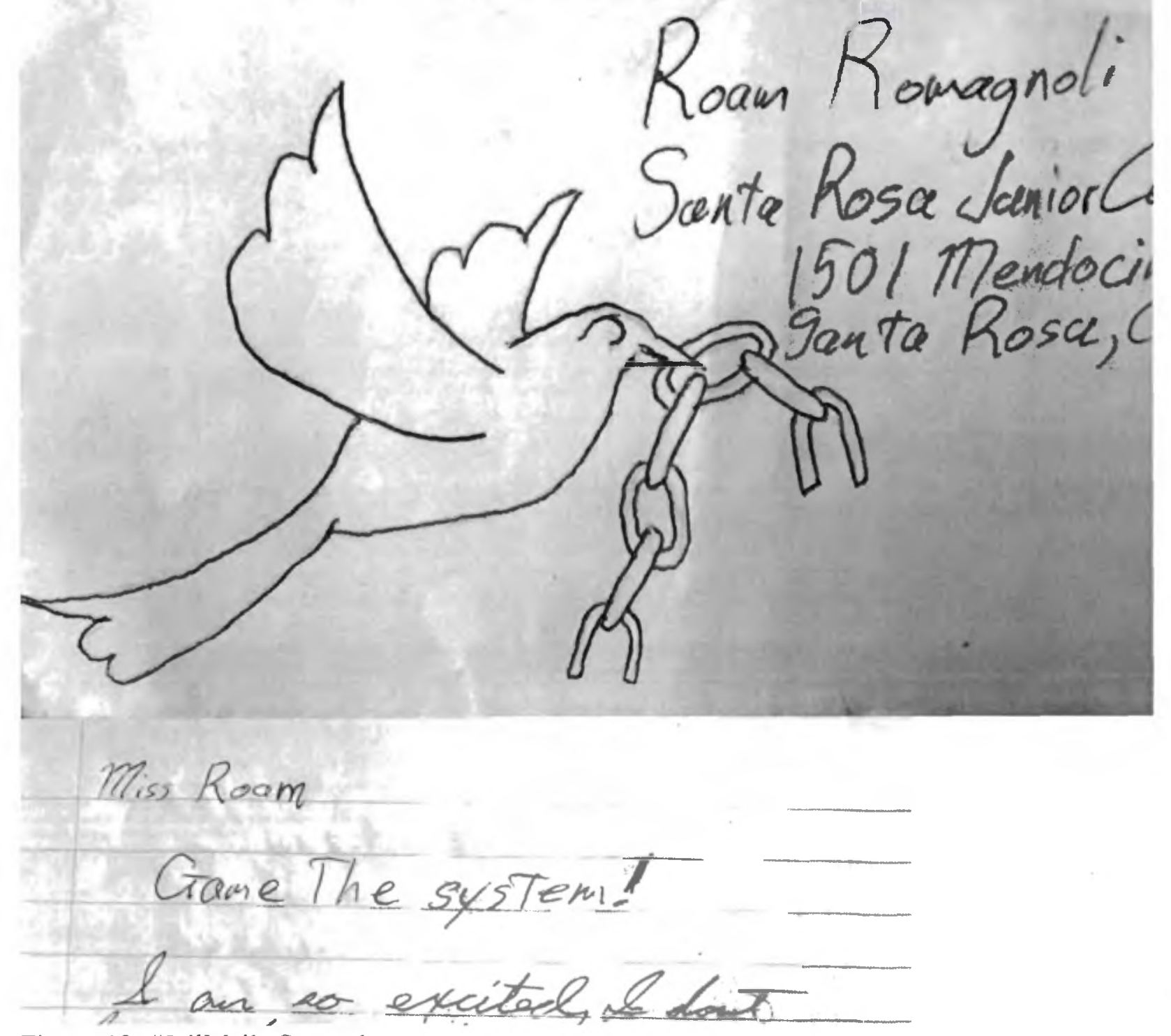

Figure 13: \#JailMail: Game the system. 
The highlight of many of my days is arriving home, or to campus, to find a letter from someone I care about who is incarcerated. I keep a regular correspondence with a couple of trans prisoners being held in medical facilities in the southern United States-it is deeply painful to address and receive their letters that must be labeled by prisoner number and birth-name, not chosen name. Additionally, during semester breaks, students from the jail where I teach will often write me, even though they know that I am not allowed to reply to them. I am prohibited from having any contact with my incarcerated students outside of our time in class together. When I return to the jail for a new semester, I hope to see the faces I expect, and I hope not to see the students who were supposed to be released over break. It is very unsettling, distressing even, to arrive to a class and have a student that I know and love be missing. Sometimes the other students are afraid to tell me (I think we should stop talking about this; there's too many ears in these walls) why someone might be missing from class - particularly if that missing student has been sent to a psych ward or to administrative segregation (ad-seg)—which is solitary confinement. One of the brightest, most passionate, and well-read students in our class missed three weeks of last semester because he was sent to ad-seg for something (even the officers said) he didn't do. I worried for him in the front of my mind every day and every night, and when he finally returned, he was a shell of the vibrant human he was before he was sent to solitary. This same student wrote me recently to tell me that the district attorney said he will be released early because he's "bad cattle"-meaning he"s 
too expensive to be worth keeping in jail because he has a disability that requires serious and costly medical care. In addition to being deeply moving and intellectually stimulating, the letters I receive from my students reflect the content of our discussions.

Below, I provide a demonstrative example of a letter from a currently incarcerated student, and then I decode it for the themes that have surfaced in the class. This student has to write in code because he knows an officer will be reading his mail before it is sent to me, and he worries that if officers found out what he was doing (trying to increase access to college classes for other prisoners), he would definitely be stopped, and likely be punished. Before I show you his letter, it will be useful to provide a little context for our class. Although I am teaching a GED prep class, and we do talk about approaches to the test, we also talk about critical issues in society. The GED prep materials I was given to teach were insufferable, banking-style workbooks; so, I asked the program deputy at the jail and the director of the jail program on campus if we could also read a novel. The directors said, maybe, and asked me to send them three possible titles. I requested The Autobiography of Malcolm X, The Handmaid's Tale, and Between the World and Me by Ta-Nehisi Coates. I received a blanket, "no" to all three options. Later the same day I asked: How about The Hunger Games? I got an immediate, "yes".

Specific to the prisons and jails, academic freedom is an issue across the vast majority of facilities and programs across the nation. I know this is not just my personal experience because most conferences dedicate multiple sessions just to getting materials 
in the door. The "rules" about what an instructor can bring in to a correctional facility are often arbitrary and mercurial...it can be different day by day, warden by warden, or guard by guard. In addition to the arbitrary rules, CDCR also has a centralized list of "banned materials" that is "available upon request." In addition to direct bans on a college instructor's academic texts and materials, teachers in GED prep programs often have no academic freedom at all; instead, they are required to use mass-produced GED preparation materials (workbooks).

In congruence with the facility's approval of The Hunger Games, a constant theme that surfaced in our class discussions about society and about the novel, as well as throughout our discussions about the GED, was "gaming the system." Here is a letter from a student (who was incarcerated at the time); I have bolded the lines I plan to unpack in the discussion that follows:

Miss Roam,

\section{Game The System!}

I am so excited, I don't know where to begin. The negative is that I am down to 5 months to go and the spring semester has already started. I don't think it will help me much, but I am a servant at heart. While it is diminishing opportunities with each passing minute, it is also one day closer to me being free to explore what the JC has for $m e !$ 
Okay, I hope your sitting down. The only way to get anything done here in the (jail facility) is to write an Inmate Request Form (IRF). IRFs are seldom, if ever, returned or answered so I have decided to write one a day every day until I get an answer. I am happy to tell you that I have received two requests for letters of explanation. I hope you will feel as excited as I am.

The first, has resulted in an open line of communication between myself and Deputy Burns and (college representative) regarding the potential to earn tablet credits at http://www.nationalccrt.org/colleges_universities/cooperating/home.html and whether the SRJC is on the list and if not who I need to talk to get them added to it. Can you help in this area? In fact, consider this letter as a release of liability on your part and a release of information act on my part. IJPO do swear that all information in this letter is public information under penalty of perjury (signed, dated)

Please share this info with whomever you feel could benefit the causes of education for inmates in the (multiple county jail facilities).

The second is about what correspondence courses we might want from the JC!!!!! I am not sure what exactly to ask for, so I am going to ask that the BOG fee waiver cover any textbooks for courses that could be offered to us here. I am also going to ask that you all help with financial aid info that inmates might qualify for to pay for textbooks and units. I would hope that every inmate in here could at least get a JAM Session and 
take the assessment test so that they could know where to start easy stuff (well, easy for me).

As far as this letter to you, I am most hopeful the assessment and textbooks would be great starts. I am also going to push for other JC books be checked out so we can use them in our cells. We spend the majority of this time in our cells sometimes 24-hours in a day and out of cell time is the only time we can shower and call friends and family so it would be helpful if books were given to individuals as if their name is on them and they go to the cell with them. Thanks in advance for your efforts and consideration in this matter.

Love Your Adopted Half Stepbrother Inlaw Once Removed, $J P$

P.S. I'm in hurry to write this so sorry its messy. Please don't grade it! Hope you understand!

I show up to every class with a "lesson plan," knowing that what will actually happen will be far better than anything I could have planned in advance. It looks something like this: 


\begin{tabular}{|c|c|}
\hline What I Plan to Discuss & What We Actually Discuss \\
\hline $\begin{array}{l}\text { The HI Set (GED) } \\
\text { Essay/Paragraph Structure } \\
\text { Thesis Statements } \\
\text { Grammar/Punctuation } \\
\text { Test-Taking Strategies } \\
\text { English and Math Placement } \\
\text { Tests } \\
\text { English and Math Pathways }\end{array}$ & $\begin{array}{l}\text { Gaming Systems: } \\
\text { Gaming Standardized Tests } \\
\text { (GED/College Placement) } \\
\text { Gaming Essays } \\
\text { Gaming the Prison Industrial Complex } \\
\text { Gaming Officers } \\
\text { Gaming Access to the JC } \\
\text { Gaming Financial Aid } \\
\text { Gaming the Math and English } \\
\text { GRemedial Pathways" } \\
\text { Gaming Me (to get what they need, } \\
\text { Gaming Emotional Intelligence } \\
\text { deserve. want) } \\
\text { Me Gaming Them (to get what I need, } \\
\text { deserve, want) }\end{array}$ \\
\hline
\end{tabular}


This list of discussion topics contains the same themes that often surface in the letters I receive from students, including the example above from JP. Here is a brief unpacking of what's visible to me under the surface of JP's text, using some of the lines I highlighted in the excerpt above.

\section{Game The System!}

The idea of gaming the system came from a conversation we had on our first day of class, when I told them we would be reading The Hunger Games. Most of the students had already ready the entire series before our first class, so we go to have a frank discussion about how Katniss, the novel's shero, is a trickster in the system meant to keep (poor) people like her miserable and enslaved-and how she utilizes the system to its own demise. We used "gaming the system" throughout the semester as a framework for discussions around beating, and even profiting from, systems meant to keep us down-like education and incarceration. JP's use of this phrase is a warm reminder of the deep intellectual conversation we shared as a class, as well as a cue that what was to come in his letter was aimed at dismantling some oppressive structure. He also centers the phrase and capitalizes it like a title, signaling to me that this is something that he has revised and polished like an academic essay, and should be taken seriously as such.

\section{I don't think it will help me much, but I am a servant at heart.}

In our classroom at the jail, we spent many mornings discussing the aims of systems like incarceration. education, capitalism, and neoliberalism. Two of the strategies 
we discuss for "raging against machines" that are meant to deny our humanity and alienate us from our fellow humans, are caring and community. There is nothing more radical for an incarcerated cis-straight White man in jail to be than caring and connected to other men. Here, JP acknowledges that his work will not benefit him, but that he is making these efforts to help other incarcerated folx who will still be there long after JP is released in a few weeks. The average stay at our county jail is 22 months, which is plenty of time for one to earn a degree or certificate.

\section{Regarding the potential to earn tablet credits at}

\section{http://www.nationalccrt.org/colleges_universities/cooperating/home.html}

Students in the jail classes asked every day why they weren't able to earn college credits for the work they were willing to do, and we had explicit conversations exploring why colleges, correctional facilities, and the public might not want incarcerated people to have access to higher education. These students' desire to attend college predated my class, and they saw me as an opportunity to further an agenda that many of them, including JP, had been pressing since before our college began partnering with the jail in 2016. These prisoners want access to high quality, credit-bearing college courses across a diverse spectrum of disciplines_-just like our students in the free world. Two or more of the men in this class, including JP, were retired and already had certificates and careers in various vocational fields - what they had never had access to was courses in the Humanities and high-quality, academic pathways. In this quote, JP makes it clear that his 
mission is to open pathways to degrees for incarcerated people. It is especially impressive that he found and included the hyperlink, since I'm not sure he's ever used a computer.

\section{Please share this info with whomever you feel could benefit the causes of education for inmates}

$\mathrm{JP}$ is aware that he is writing not just for me, but for a larger audience of folx who share our interest in expanding incarcerated students' access to rigorous academic pathways. He gives me permission to use and share his writing, reinforcing that what he is after is greater than himself...it's about disrupting a predatory system of mass incarceration.

I am going to ask that the BOG fee waiver cover any textbooks for courses that could be offered to us here

Here, JP demonstrates that he knows how to help incarcerated folx suffering from poverty get their education paid for-a way to game the (rigged) system of financial aid/tuition.

I would hope that every inmate in here could at least get a JAM Session and take the assessment test

In this selection, JP advocates that everyone in the jail should have access to the assessment test, as well as to the JAM sessions our college provides to help students game this test that determines their academic and economic future. 
JP makes so many brilliant moves under the surface of this letter, all aimed at gaming exploitative systems (incarceration, education, capitalism, neoliberalism). Sadly, JP was released from jail to learn that his mobile home had burned down in the wildfires that ravaged our county while he was incarcerated. I showed up to my office on campus one Monday to find him crumpled, crying, filthy, and starving at my closed office door. He had been released from jail the previous Friday, but because campus was already closed, he couldn't get his student ID card which would have allowed him to ride the city and county buses for free. Instead, he had trekked with all of his belongings (which he had hidden in some bushes behind campus) up and down the county on a futile search for an "Obama phone."

We immediately went and got him a student ID/bus pass, and I took him over to our new student resource center that is beginning to connect students with community resources for food and housing and other basic needs. He was so tearful that we immediately went over to Student Psychological Services to schedule him an appointment (they "couldn't get him in" until the following day). Then, finally, we went over to our Student Equity office, where I set him up with a student success coach that would help him find a Counselor and enroll in classes. I gave him a quick hug and had to rush off to teach with a knot in my stomach because I was sure that he was overwhelmed, and I feared I'd never see him again.

And I didn't. 
There is incredible work being done by the faculty on the ground of California's prison and jail higher education partnerships, but we have great work yet to do to expand incarcerated students access to academic pathways while they are incarcerated, as well as to help our students transition from our classrooms in correctional facilities to our campuses in the free world. The voices of system-impacted students and community college faculty are blaringly absent from the research and decision-making taking place around these programs. This chapter ends with some implications for individual faculty members, and the next chapter focuses on program-level findings and implications. The majority of the faculty teaching inside jails and prisons are, at least in my experience, White womxn; my implications are framed accordingly.

\section{Implications for (especially White) Practitioners in Prison Higher Education}

The most important implications for improving the quality of teaching and learning inside correctional facilities include: diversifying and compensating faculty, maintaining academic freedom in correctional facilities, providing orientation and (ongoing) professional development aimed at improving pedagogy, and engaging in international conversations about the possibilities for prison higher education.

Faculty pay is essential to diversifying the teaching force, to valuing this crucial work aimed at healing our communities, and to disrupting the White savior and prison industrial complexes. Faculty pay might seem like an implication for programs, and it is, but it is also an implication within the scope of individual faculty. If largely White and 
wealthy faculty continue to teach for free without advocating for pay, then faculty from oppressed groups will continue to be disenfranchised from these spaces and from the field of prison higher education. In addition to teaching faculty demanding that our labor be valued, we should also be holding our programs and institutions accountable for cultivating our professional development and for supporting our long-term economic, psychological, and emotional vitality.

It is important to be explicit about the fact that a great deal of the incredibly highstakes (emotional, physical, psychological) labor in this field is being done by contingent labor-mostly womxn-many without access to comprehensive healthcare coverage. I have the privilege of being tenured faculty; however, my college required me to teach as an adjunct in the jail on top of my full campus load. I spent countless hours in therapy processing the trauma I was experiencing inside the jail, and I have relied heavily on the privilege that I have to be able to use my insurance to afford to see a therapist.

I am not alone.

Shawn Ginwright, critical education scholar, has recommendations for moving beyond trauma-informed pedagogies and towards "healing-centered engagement" that are incredibly relevant for prison higher educators. Ginwright (2018) illuminates the fact that trauma-informed care involves a slippery slope that pathologizes the individual and ignores the collective trauma some communities face at the hands of harmful systems. Ginwright explains, "if trauma is collectively experienced, this means that we also have 
to consider the environmental context that caused the harm in the first place. By only treating the individual, we only address half of the equation leaving the toxic systems, policies, and practices neatly intact". Two aspects of healing-centered pedagogy that are most relevant to prison higher education are that it maintains that well-being comes from participating in transforming the root causes of harm, and it calls for the intentional support providers need with their own healing. Prison and jail higher education program coordinators, faculty, and staff must have our own healing considered and facilitatedcorrectional staff does not escape this collective trauma, and we should care about and support their healing as well.

Community college faculty teaching inside also cannot wait for people of color or academic coursework to lead us to critical theory, critical self-reflection, and critical pedagogy; we must engage ourselves in this work deliberately and daily. We must do research, even though it may not necessarily be required of us. We must reject "bootstraps" narratives of education and remedial approaches to learning (and to students), and we must do advocacy work beyond the classroom; in particular, we can create and advocate for structural changes aimed at decarceration in policy and practice in correctional facilities, in courthouses, in our p-12 schools, in our higher education programs. and in our local and state governments. Individually and collaboratively, faculty must carve out policies and contracts that expand paid opportunities for systemimpacted folx and other minoritized groups, that value our intellectual and emotional 
labor, and that support our professional learning, our research, and our participation in regional, national, and international conferences.

If we do not want our efforts in the classroom to perpetuate the prison and/or White savior industrial complexes, then (especially White) teachers must take our work beyond the classroom and prison walls, beyond our individual students, and above all, beyond ourselves and our own sentimentality for education and incarceration. Enacting a critical approach to pedagogues and pedagogies means that teachers, especially those doing work in correctional facilities, have to employ their personal politics and their curriculum against the reproduction of systemic social ills like incarceration and remediation. This means adequately resourcing teachers and advocating for prison higher educators' access to professional learning aimed at enacting critical, healing-centered, and humanizing pedagogies.

This is a great discovery, education is politics!

When a teacher discovers that he or she is a politician, too, the teacher has to ask, What kind of politics am I doing in the classroom?

That is, in favor of whom am I being a teacher?...

The teacher works in favor of something and against something.

Because of that she or he will have another great question, How to be consistent in my teaching practice with my political choice? 


\section{I cannot proclaim my liberating dream}

and in the next day be authoritarian in my relationships with the students.

(p.46, Shor \& Freire, 1987). 
Chapter Four: Report of Findings

\title{
A Critical Trans Politics Approach to California's Prison Higher Education
}

\section{Partnerships}

\author{
What do we make \\ of the flowering vine \\ that uses as its trellis \\ the walls of a prison? \\ -Jackie Wang
}

There are some critical tensions underlying the tremendous growth and energy surrounding California's prison higher education partnerships. These tensions are important to explore so that we can be sure that the programming we are providing in jails and prisons truly reflects the values of our open-access institutions. Here are a couple of related critical questions that Jackie Wang's poem raised in my own mind: What do we make of our own efforts to create higher education programs that make prisons more humane? What do we make of individuals and organizations that profit from prison higher education programs? These questions, and my dissertation as a whole, are strongly informed by an emerging group of scholars interested in exploring the role of higher education in prison abolition - much of this research reflects a move beyond deconstructing the school-to-prison pipeline, to dismantling a school-prison nexus (Annamma, 2017; Lawston \& Meiners, 2014; Meiners 2016; Meiners 2017; Stovall. 
2015). Now, instead of majoring in Administration of Justice or Criminal Justice, scholars interested in disrupting the prison industrial complex can study with abolitionist scholars in fields like Critical Criminology, Queer Criminology, and Carceral Feminism. Abolitionist scholars are infiltrating more popular and traditional academic spaces with abolitionist rhetorics; for example, the title of this AERA (2018) working group, "Building the Radical Imaginary Now: Abolitionist practices and movements to end our carceral state." The goal of this workgroup was to, "bring together educators, organizers, and scholars working in educational and community spaces to discuss the intersections of prison abolition and education" (AERA, 2018). This dissertation is deeply informed by my immersion in the scholarship of these radicals.

This final dissertation chapter moves from the practitioner-level of analysis embodied by chapter 3 , to a program-level of analysis using a constructivist grounded theory approach of critical inquiry that addresses power, inequality, and injustice (Charmaz, 2017). Consistent with grounded theory methods, I have collected, coded, and analyzed a tremendous amount of rich data from a wide variety of sources (Charmaz, 2014). A primary source of data for this study has been the California Community Chancellor's Office Inmate-ed listserv, which includes practitioners from almost every program in the state. Practitioners include faculty, academic counselors, program coordinators, policy experts, and classified staff. The threads on this listserv are always centered in the most important conversations happening across the California Community 
Colleges (CCCs); for example, there is robust discussion taking place right now about the exciting potential of new policies like AB 705 and Guided Pathways in correctional facilities. I have also conducted dozens of informal interviews with currently and formerly incarcerated students, correctional officers, prison/jail educators, program coordinators, and higher education policy experts specializing in supporting systemimpacted folx at the local, state, and federal levels. I went through multiple rounds of coding the transcripts of all of these interviews, my field notes, and the related data memos. I also conducted and coded six (6) formal, in-depth interviews with state and federal higher education policy experts and six (6) same-style interviews with directors of prison higher education programs offering pathways to and through upper-division coursework in prisons in California and across the nation.

My findings and implications are grounded in these interviews and listserv discussions, as well as in the most current conversations happening in the field of Prison Higher Education at the national and international levels. As part of my research in 2017, I attended both The National Conference on Prison Higher Education in Texas and The European Prison Education Association's international conference in Austria. In 2016 and 2018, I attended The Prison University Project's regional trainings for prison higher education practitioners, and 1 attended several of California's regional summits for correctional educators and for community colleges participating in partnerships with CDCR. In attending these conferences. 1 learned the most from the conversations 1 had in 
hotel lobbies between formal sessions with practitioners in the field-many of whom are troubled by trends they see, but who feel too vulnerable to speak out. These are some the most important voices represented in this dissertation-the voices of the program coordinators and faculty doing the work on the ground. Finally, the findings and implications for this study also reflect my personal experiences as a queer community college faculty member teaching inside and working to end incarceration by building partnerships aimed at expanding incarcerated students' access to higher education for many years.

In the course of my study, three primary areas of findings emerged: Funding, Student Services, and Turf Wars. It is important for me to be explicit that this dissertation study is grounded in a Critical Trans Politics approach, which means I am openly ideological about the imagination I share of a world without the prison industrial complex, colonialism, ICE, sexual violence, and wealth disparity. I chose a critical trans framework because it demands more than legal recognition and inclusion; instead, Critical Trans Politics aims to transform current logics of state, civil society security, and social equality (Spade, 2016). For this study, operationalizing Critical Trans Politics means enacting a transformative, abolitionist approach to prison higher education programming by supplying direct aid to the front lines first. Dean Spade, a prominent critical trans legal scholar offers the following question and criteria that can serve as guides for practitioners doing abolitionist work in any field: 
Question: Is this tactic/reform/approach recuperating systems and institutions we want to dismantle?

\section{Criteria:}

- Does it provide material relief?

- Does it leave out an especially marginalized part of the affected group (e.g., people with records, people without immigration status)

- Does it legitimize or expand a system we are trying to dismantle?

I employ these questions as a framework for the findings and implications I discuss in the coming pages. It is vital that prison higher education practitioners crystallize, and become explicit about, the purposes of our prison higher education programs because those of us that are interested in using prison higher education programs to empty prisons are in danger of watching these programs actually be recuperative (beneficial) for the prison industrial complex. To be clear, in my mind, the singular aim of prison higher education (and of this dissertation) is abolition: of jails and prisons, cops, ICE, the prison industrial complex, and all forms of sexual, gender, economic, and educational violence. A critical trans politics approach to prison higher education can be a powerful mechanism for practitioners interested in creating dynamic partnerships between colleges and prisons that aim to empty prisons...or even better, render them obsolete (Davis, 2003). 


\section{Program-level Findings}

The most important question not being asked at the state level is, what are the aims of the partnerships California is legislating (and funding) between CDCR and the California Community Colleges? Specifically, what are the goals and values driving these college programs? Since California Senate Bill 1391 passed in 2014, California Community Colleges (CCCs) went from one program in one correctional facility in 2015 , to colleges offering courses in 18 different correctional facilities now in 2018. Of course this is great news, and a long time coming, for both incarcerated and free folx who have been advocating for the reinstatement of these higher education programs in prisons, since $90 \%$ of the existing programs died when Bill Clinton's 1994 Crime Bill banned incarcerated students' access to Pell Grants.

Although the new commitment to funding prison higher education programs is exciting, these brand new programs are operating entirely independent of one another, often without sufficient strategic planning or support, and without any measures of transparency or accountability for the quality of the services they are being paid to provide to incarcerated students. The findings and implications discussed in this section are broken down into three major areas, including the current funding climate for prison higher education programs in California; disparities in student services; and the turf-war between GED, workforce prep, and academic pathways. 


\section{Finding Area 1: The Funding and Research Climate for California's Prison}

\section{Higher Ed. Programs}

"It could be fantastic, but if we allow institutions to come in and do it as cheap as possible with little investment, it will be garbage. It will be one of those things in the prison system that's called better than nothing."-Jody Lewen, Director of Prison University Project

Funding is a dynamic and continuous thread that emerged across data sources and at every level of conversation in the field of prison higher education. There is no guide or list of best practices for community college practitioners to follow when starting these programs, so colleagues are our best resources. The "Inmate-ed" listserv provides a platform for practitioners to discuss approaches to funding various aspects of college programs including books, library services, instruction, tutoring, tuition for non EOPS students and many other funding caveats. Additionally, funding is a theme that surfaced heavily across regional and national conferences. For example, the 2018 "Leading the Nation: Building excellence for California's incarcerated and formerly incarcerated students" conference featured a session titled, "Don't Stop Now: Planning for the Long Term." Here is the part of the description for this breakout session: "Sustainability matters whether you are working in custody or on campus. How do you build institutional support? How will you be affected by the proposed categorical and funding formula changes?" There is also an intense debate at the national level regarding what 
ethical funding looks like for prison higher education partnerships. For example, at the (2017) National Conference for Prison Higher Education, the directors of two of the leading programs in the nation debated the ethics of prison higher education programs accepting large donations from organizations that also finance private prisons and the prison industrial complex. At this moment in California, there is a great deal of confusion about how to fund college in prison programs, and there is simultaneously very little transparency in terms of what community colleges are spending on these programs. This confusion makes a great deal of sense, as California went from one, to 18 prison higher education partnerships in less than two years.

There are numerous factors at play in the swift expansion of prison higher education programming in California, but it is California's 2014 senate bill that enabled community colleges to collect funding for offering programming in correctional facilities. This bill is the catalyst for the numerous prison and jail higher education partnerships emerging across the state. Specifically, the bill reads:

On or before March 1, 2015, the Department of Corrections and Rehabilitation and the Office of the Chancellor of the California Community Colleges shall enter into an interagency agreement to expand access to community college courses that lead to degrees or certificates that result in enhanced workforce skills or transfer to a four-year university. (SB 1391) 
At the same time as community colleges are being incentivized by the state to form these partnerships, many of California's community colleges are suffering from crises of declining enrollment - a trend expected only to get worse over the next decade (Smith, 2018). Additionally, federal, state, and local government policy have increased demands on correctional facilities to offer more education programming. As a result of these factors, many of these new prison higher ed programs are being built under enormous pressure from colleges hurting for enrollment, as well as from CDCR officials that need to be in compliance with the law-and both stakeholders want access to the available funding. The mechanisms community colleges use to fund prison higher education programs determine the types of courses a college can provide.

The majority of community college programs operating in correctional facilities are only providing an extremely limited scope of course offerings and typically focus on certificates, distance education, workforce preparation —almost always to the exclusion of degree/transfer pathways in non-workforce related fields. This information is available on the "Corrections to College" website's Program Directory. The primary reason for this limited scope of offerings that emerged from the data was funding restrictions, like those that apply to programs funded by the Adult Education Block Grant (AEBG), in which monies can only be used to offer non-credit courses. This trend raises an important dilemma for the community colleges: is it ethical for open access community colleges to funnel incarcerated students who are almost always some combination of poor, disabled. 
queer, people of color, into "workforce prep" programs without also providing them access to academic pathways? It is important to note that workforce prep is not the same as Career and Technical Education, or CTE. True CTE pathways, as federally mandated by the Perkins Act, must provide an integrated education that includes academic coursework and a potential pathway to transfer. Workforce prep programs can be run without the often costly manipulatives necessary for true CTE and without the cost of the instruction and student supports necessary to providing a high-quality academic pathway.

As more funding becomes available for education programming in correctional facilities, so grows the competition for this funding. Typical competitors for funding can include, but are not limited to correctional employees (who often teach GED and other "life skills" courses); community colleges; charter schools; faith-based organizations; community based organizations; and now, both public and private four-year universities. Prisoners represent potential capital to all of these stakeholders, which can foster a goldrush-like mentality across programs and institutions-especially those institutions with enrollment crises. This is a problem Jody Lewen addressed in her opening remarks at the most recent (2018) Prison University Project's "Statewide Training Conference on Higher Education in Prisons" saying:

SB 1391, on the one hand that was kind of thrilling, for obvious reasons, because then the schools could come in (to prisons), but what we also saw was schools that are like, oh GREAT, because our enrollment is kind of low and lf we go in 
there we can get some students enrolled, and we can collect some apportionment funding which really need, and then we can fill some funding gaps that we are experiencing.

So the approach to the prisoner, to the incarcerated student, was as a source of revenue, and that, to me, is deeply problematic... if you are in a situation where the program that you are working with or that your institution is building is being shaped to maximize revenue, start really making noise.

Jody is a pioneer and highly respected practitioner in the field of prison higher education, since The Prison University Project (PUP) is a the longest-standing program in the state. In 2016, President Obama awarded Jody and PUP with a National Humanities Medal for its high quality, rigorous higher education programming. Reifying Jody's fears about a profit-driven approach to prison higher education partnerships, one of the California prison higher education policy experts that I formally interviewed remarked: "Community colleges that are not experiencing enrollment crises are largely disinterested in starting these (prison higher ed) partnerships." This is one of those critical tensions that requires program coordinators to be vigilant when faced with the prospect of cutting corners to increase profit.

In July 2018, Stanford's "The Opportunity Institute" utilized this language on their website to announce a $\$ 5$-million-dollar incentive to match for community colleges desirous of building programs in jails or prisons, "The $\$ 5$ million will be allocated to the 
California Community Colleges Chancellor's Office and awarded to community colleges through a competitive request for proposals process that will require community colleges to provide matching funds."

It is clear that the process is competitive, and that community colleges will have to make their own monetary commitment (in a time of highly restrictive and shrinking budgets), but there are no "best practices" or guides for institutions or for program coordinators in terms of budgeting or program offerings. According to conference panelists and listserv participants, funding and spending look a little different in every college prison partnership. Based on what emerged from the data collected from the inmate-ed listserv and my informal interviews, what looks the same across programs is that prison and jail program coordinators are being asked to offer more courses and faster, without necessarily being provided with more money and support to sustain this growth. Program coordinators often feel they don't have the funding or freedom to offer the quantity and quality programming they wish to provide, and that their correctional facility is pressuring them to provide.

There is much interesting discussion on the inmate-ed listserv, and little actual transparency from college programs, in regards to funding prison and jail higher education partnerships. Some community college programs rely solely on state funding streams distributed by the chancellor's office, while others might embrace philanthropic and/or corporate partners-for many of us, particularly for abolitionists, this is a 
potentially foreboding practice in the field. There are several arms of state funding at play, including equity funding, EOPS, AEBG, (4) grant-funded pilot programs, and otherwise earmarked monies. Many programs use their college's Equity funds to pay for incarcerated students' books, and they are able to cover tuition for most students using the BOG fee waiver. Beyond that, the access a program coordinator has to actual funds, and the power that they have to determine how to spend those funds varies, although it tends to be extremely limited. Some program coordinators are not able to access any funding at their institutions other than grant monies like the Adult Education Block Grant, which can only be used to provide non-credit coursework. Many coordinators sharing their experiences on panels described feeling paralyzed and perplexed by the restrictions on their various funding streams.

A tremendous amount of positive press from research and policy organizations has further energized the movement for prison higher education in California. The progress California has made with the catalyst of the senate legislation is exciting, but many of us working in these programs would disagree that we have something other states should be modeling just yet. The (well-intentioned) positive public press being mass produced by elite in-state groups like "Corrections to College California," an arm of Stanford's "The Opportunity Institute," as well as out-of-state groups like Center for Law and Social Policy (CLASP), does not reflect the experiences of some of the most 
vulnerable people doing this work on the ground, and these types of press releases make no mention of the quality of the programming being provided.

My substantial review of California's prison higher education program literature revealed that college programs and research institutes often claim that the primary aims of prison higher education partnerships are to reduce recidivism (by training incarcerated people for jobs) and to save the state money, often reproducing the narrative that it's cheaper to educate someone than it is to incarcerate them. The research and policy analysis being produced away from the ground sustains a narrative of personalresponsibility, where education and/or a job promise to transform an incarcerated individual's life. This paradigm raises an important consideration for colleges, universities, and policy agencies: as we continue to build programs in jails and prisons, we will have to be conscious about the extent to which our programs address or ignore the larger problem and historical context of a harmful system of mass incarceration that has a demonstrable pattern of preying on the lives of black, queer, poor, and disabled communities. This is perhaps the most critical, and uncomfortable, tension in the field of prison higher education.

Practitioners in the field are raising penetrating questions about the implications of having prison higher education programs that are funded by private corporations (like "Bank of America" and "JP Morgan Chase") that profit from private prisons and grow the prison industrial complex. This debate was especially lively at the NCPHE (2017), 
where Koch Industry sent a scout who claimed to be there, "looking for potential projects the Kochs might deem worth funding." At the same conference, in a session titled "Fundraising 101," that aimed to, "provide a crash course in the basics of fundraising for in-prison higher education and reentry programs, as well as a broader discussion of the topic," one program coordinator on the panel, a person of color, described the current funding climate for prison higher education like this, "Right now I just have this image of funding where it's like this old White man, and I have to be like, 'Please massa,' and that's the way we set it up." This conference and listserv topic is also surfacing in a broader conversation about the privatization of criminal justice reform efforts.

A recent article in The Nation titled, "Beware of Big Philanthropy's New Enthusiasm for Criminal Justice Reform: Wealthy donors across the political spectrum are zeroing in on our jails and prisons as the latest locus of privatization," (Chen, 2018) warns practitioners in the field about this trend:

The bottom line of community corrections is that after infiltrating education, healthcare policy, cultural institutions, and prison, wealthy donors and private industry are promoting similar kinds of smallgovernment politics by privatizing criminal justice. But if prison reform is just another "investment" rather than a societal crisis response, then capital will end up where it's always found a home in the carceral state: Above the law......The Charles Koch Institute, which aims to promote 
"free and open society" through libertarian policy and education programs, has launched a new initiative for criminal-justice reform that seems benevolent enough, investing private funds in "second chance" programs to expand opportunities for the formerly incarcerated. But these efforts reflect a broader social engineering agenda of promoting the libertarian vision of a "free society" which champions individual and property rights while shrinking government.

It is important for practitioners in California to be conscious of this larger conversation so that prison higher education programs don't unconsciously recuperate the prison industrial complex. Major prison corporations like GEO and Core Civic have been first in line to get reform contracts for the same types of diversion, rehabilitation, and "residential reentry" programs that are starting to appear in California. This theme of recuperative funding surfaced in my field notes from informal interviews and conference discussions, as well as in my formal interviews. One rural program coordinator who has already been faced with this dilemma said she would never sleep again if the only way that she could keep paying her teachers was to take money from sources that perpetuate the prison industrial complex: "I will never say, you have a job because we are now a part of the criminal justice system. I would quit first." This is an excellent example of the diligence many practitioners see as necessary to maintaining the integrity of the field. 
Although there is tremendous funding available for the production of research, this funding isn't trickling down to those who need it most on the ground, nor does it do anything to disrupt the actual problem of a predatory system of mass incarceration. Khalil Gibran Muhammad, cited in "Universities Are Hotbeds of Scholarship on Mass Incarceration. Are They Doing Enough to Fix the Problem?"'(Parry, 2018) affirms, You can be a policy agenda-setter, and contribute to a set of draconian policy choices, and there's no consequence to your lived experience or the people you care most about, for the most part. A major shift in the activist community, and in the nonprofit sector, and for a smaller group of academics, is to close the gap between the policy-research community and the actual people who will feel the consequences of those policy outcomes (p.2).

That is why the intended audience for this dissertation is practitioners and students doing the work. It is the program coordinators and faculty on the ground who need information, resources, and support.

In theory, the problem sounds harmless, if a problem at all: a bunch of community colleges racing to offer programming in correctional facilities. In practice, some of these community colleges may be scavenging for funding to ameliorate their own budget shortages caused by enrollment crises. Yet, as colleges use prison higher education partnerships to generate positive social capital through the press, make considerable 
profits, and balance their own budgets, it is important to make sure this isn't happening by offering cheaper, under-resourced versions of on-campus courses in jails and prisons. Currently, there is no transparency or guidance for the tremendous amount of capital pouring into and out of these programs - this is cause for question, since an argument can be made that public funds are being misused by community colleges in some cases.

While colleges continue to spend undisclosed amounts of money on these programs, they can often be simultaneously underfunding these same programs. Across the state, and across the nation, these programs are run on the backs of womxn who are being forced to offer more with less: more students and more sections without more faculty, classified staff, training, etc. This is a theme that emerged across my field notes from conference panels and informal interviews. As a result, some programs offer the cheapest possible programming (GED/Workforce Prep, for example) and meet as infrequently as possible, often returning to correspondence courses or opting for "hybrid" courses - meaning they meet every other week, instead of every week. Here is one program coordinator's response to being pressured by her academic institution to offer (cheaper) correspondence courses:

Roam: What are your thoughts about correspondence or "distance ed" courses? 
Program Coordinator: I was getting a lot of push back and being told, if you offer these classes, then these guys can get through faster, and my response is, well what is the goal?

If the goal is to just to make sure all these guys have a degree, okay then fine, but my goal is to make sure that they're educated, and that they feel valuable and have hope and they understand what they learn...they aren't just copying something out of a booklet so that they don't reoffend.

The critical finding here is that in this moment, many California Community Colleges (both intentionally and unintentionally) are already exploiting, or are in danger of exploiting an opportunity for fast funding without enough concern for quality, student success, or equity; in effect, many community colleges are focusing on non-credit and/or offering subpar programming that minimizes spending and maximizes revenue. Further, there is no transparency or accountability for the funding and spending of these proliferating college higher education programs, or.for the quality of the programing taking place in correctional institutions. Up and down the state, programs are rushing to increase offerings in hurried response to crises in enrollment on campuses, and in response to increased demands of CDCR catalyzed by new state and federal policies. 


\section{Implications for a Critical Trans Politics Approach to Funding Prison}

\section{Higher Education Programs}

\section{Conscious funding practices.}

Considering Spade's guiding question and criteria for critical trans politics in terms of funding means being intentional about both where the money for these programs comes from, as well as where the money lands. Prison higher education programs have serious work to do in order to prevent our well-intentioned programs from recuperating the prison industrial complex. Practitioners must ask whether the vast amounts of cash exchanging hands across the partnerships between elite universities and philanthropic/corporate donors is actually manifesting into any material relief for the most impacted groups on the ground: incarcerated students (most important) and program faculty and staff doing the work to run the programs inside the facilities.

All across the state and the nation, there are prison and jail higher ed programs, as well as reentry programs, scraping to get by on the blood, sweat, and tears of a small handful of committed, warrior faculty, staff, students, and volunteers. One California community college prison educator recently and poignantly quipped in an informal interview, "Why is Stanford dangling a 5-million-dollar steak in front of our starving faces?" To address Spade's second question, the most marginalized groups of incarcerated students, and of community college faculty and staff, currently appear to be largely "left out" of the available material relief altogether. Faculty in the poorest, most 
rural areas are least likely to be highly-compensated, and incarcerated people from minoritized groups are being fully denied access to many of our programs. This is not sustainable and is ethically questionable. The most direct solution to this funding problem is for the state to fully fund our community college and CSU systems by making them tuition-free for all (free and incarcerated) students. Period. This is how we give the most direct aid to the frontlines first, and cut the middle-organizations out of the funding formula. We are on our way there with the California Promise, but it is important to be sure that as these types of reforms expand, they don't include limitations that might ban system-impacted students.

It is especially important to investigate the finances of community college programs in correctional facilities because how these efforts are funded has direct implications for our democracy. In Carceral Capitalism, Jackie Wang (2018) breaks it down like this, "As the public debt is financialized and the money to cover government expenditures is increasingly supplied by the financial sector, government bodies become more accountable to creditors than to the public. Over time, this has a de-democratizing effect." In other words, education is not a corporate commodity, but a public good and should be paid for with public funds. If we create a system where private corporations and philanthropic groups are primarily responsible for funding community college programs, we are in danger of prioritizing the needs of corporations over the needs of fellow community members. This appears to be what is happening when programs are 
more concerned with creating a strong workforce than a thriving community or a strong, participatory, and diverse democracy.

A further critical divestment, or re-investment, can be made throughout public P12 education, and in particular in the CCCs and CSUs, by diverting funding away from campus police and toward more pro-social, anti-punitive campus and community supports for students; for example: school therapists, social workers, after school programs, rehabilitation counselors, success coaches, mentors, gardens, foster youth services, healthcare, housing support, and other human needs that can/should not be met with a weaponized, carceral approach. Campus police do not deter violence-what they actually do is feed the school-to-prison pipeline (ACLU, 2016; Nance, 2016; Ritchie, 2017). Campuses with larger populations of students of color are more likely to use surveillance technologies and to use police (instead of an administrator) in disciplinary actions. This is an exciting opportunity for California to continue being a pioneer in a movement toward decarceration-we are already leading the way with our divestment from ICE and private prison contracts. In addition to adopting these types of critical practices, funding for prison higher education partnerships can be better distributed to the front lines if we create more dynamic coalitions across a broader range of institutions and services. I include this as part of the funding implications because restrictive funding streams impact a program's capacity to build coalitions across agencies. 


\section{Dynamic partnerships for decarceration.}

Instead of competitive silos, community college prison and jail higher education coordinators should be encouraged (and paid) to work in myriad forms of radical collectivism that implore agile, robust, and relevant community partnerships, as well as ongoing engagement in discussion, supports, and professional learning. The Chancellor's Office should fund a coalition of practitioners that provide best practices, that model high-quality and high-integrity programming and funding practices, and that ensure that the dollars make it all the way to the students and their supports on the ground. In addition to creating coalitions across practitioners, community colleges can also form more even more diverse and robust partnerships with agencies serving myriad human needs.

We can look to CSU Fullerton students for inspiring examples of collectivism and frontlines-first action; here is a (2018) press release from their Facebook page:

In August, we will launch the first collegiate reentry housing initiative in the nation, providing life-affirming off-campus housing and wraparound support for formerly incarcerated students. Help our students reach their full potential by donating books to our library!

"Nothing about us without us" was an important system-impacted-student-driven theme across prison higher education conferences I attended over the last several years that relates to both funding and research. System-impacted students are tired of having 
critical programmatic decisions made, and research conducted, about them, without them. This same logic applies to the community colleges-community college practitioners must be the leaders of our own movement, we must engage in the re/production of our own data and research, and we must not be held hostage by the narratives and aims of corporations or the state demanding that we build programs designed to "create workers", "save money", and "reduce recidivism", or by the needs of our institutions that need to bolster enrollment and balance budget shortfalls. The state of California is one of the wealthiest economies in the world. In a state that is wealthier than most other countries, there is enough money to fund higher education for all. Not that long ago, we did.

Currently, there is simply not the will. On a more hopeful note, one California higher education policy expert I interviewed fantasized about a form of direct aid she refers to as "legacy programming":

When you make a decision to pursue a higher education, that is a legacy moment, that is not just a moment for yourself, that is a legacy moment for your entire family, and for everyone that's going to come after you. So one of the things I'd like the state to explore, is that if you have an incarcerated student who completes a progran, then what that might trigger is some kind of opportunity for his or her children or grandchildren to get some type of special scholarship or some kind of additional financial help. (Prison Higher Education Policy Expert) 
Programming like this puts direct resources in the hands of families most impacted by the intergenerational trauma of mass incarceration - a critical tenet of a critical trans politics approach to prison higher ed programming. These implications for funding and partnerships are aimed at disrupting what could become a trend of reinforcing the very structures that we (at least some of us) are trying to dismantle. The discussion about how to ethically fund these prison and jail higher education partnerships continues, and it will be important for California's practitioners to continue to be conscious of the larger social implications of these programs as we continue to grow them.

\section{Finding Area 2: Disparities in Quality of Instruction and Student Services}

I feel that it is important to make note at the beginning of this section about the impossible situation in which it seems most program coordinators find themselves. Program coordinators in California, and across the nation, are almost all womxn, many of whom are womxn from communities of color. Every program that is currently alive at all, exists only because of the countless unpaid hours of these warriors for educational justice. These womxn are sheros. Unfortunately, they are sheros with "bosses". In the CCCs, these bosses are deans, VPs, and other administrators. In addition to bosses on campus. partnerships involving colleges and universities, corrections, corporations. and philanthropy, bring new bosses like funders and correctional officials, that can also look like the same White men described by the program coordinator in the previous section. In 
addition to being precariously (under)funded, there is also tremendous instability in the broader world of public education, as well is in the more narrow field of prison higher education-both are subject to the whims of the White House, which is expediently obliterating funding for education and social programs. Simultaneously, this administration is moving away from what was a new approach to criminal justice that focused on rehabilitation, and back toward an extremely punitive, financially exploitative approach to criminal in/justice.

As this political landscape continues to unfold, much of the data I collected in the form of informal interviews and field notes from conference conversations revealed that many program coordinators find themselves with little power and no job security; as a result, they stay silent (for fear of being replaced) when their bosses make unethical or impossible requests of them. In addition to facing the demands of the academic institution, program coordinators also deal with a host of bosses and rules and demands from correctional facilities. The demands that program coordinators are facing to increase course offerings without receiving increased funding and support, means these program coordinators often have no choice but to cut corners - corners it would be unacceptable, even illegal, to cut on a college campus. My formal and informal interviews revealed four primary examples of community colleges providing inequitable services in jails and prisons: the breadth and quality of instruction/instructors, the absence of disability and other student services, and the provision of gender-biased programming. Program 
coordinators speaking on conference panels related to hiring frequently lamented their program's inability to supply enough education programming to meet the demand/desire at their correctional facilities:

"We can't afford to offer what we actually want to offer"-Program Coordinator "We have waitlists on every yard that are so big, we can't even keep count. We are talking about a hundred-plus people everywhere."-Program Coordinator I heard this over and over again in formal and informal interviews. Of course, when I ask why, the answers are the same: we can't afford to hire and pay enough quality instructors to meet the needs of our correctional facility.

\section{Breadth and Quality of Instruction}

The (potential) students exist by the thousands, and CDCR is making sure the space is available for classes to take place, but programs can't afford to hire and pay enough quality teachers to staff prison higher education programs. Several program coordinators that I formally and informally interviewed admitted that the teachers they were hiring to teach inside jails and prisons did not have the currency or the requisite credentials to teach in the same discipline on campus. There is a fair amount of reliance on "emergency hires", contingent labor, and on retired and volunteer elementary educators across programs in jails and prisons-close to none of these teachers are provided with professional development, particularly not in terms of critical pedagogy. 
Additionally, many programs do not pay faculty teaching inside a wage that reflects the complexities and difficulties of teaching in a correctional institution. I informally interviewed the majority of California's program coordinators about this subject using my access to the inmate-ed listserv; although several coordinators have been able to get their teachers paid in load, nearly all of the program coordinators that replied lamented not being able to pay teachers for the additional time it takes to teach a class inside. San Quentin is seen as a "destination prison" because of the quality of The Prison University Project's student-centered academic programming. The PUP program is able to maintain this stellar reputation largely due to the deep pool of Berkeley, SFSU, Stanford, etc. instructors that volunteer to bring high-quality education to students in a highly supportive program environment that includes ongoing professional learning. This is largely impossible for California's community colleges to replicate-particularly those community colleges located in areas of California where most of our prisons are located, and none of our elite universities. Here is how two different program coordinators described their hiring struggles in formal interviews:

Roam: Do you have any trouble hiring teachers? Do you have any challenges recruiting and/or retaining faculty?

Program Coordinator: Oh yeah. I think finding them is the hardest part... Roam: Why? 
Program Coordinator: A variety of issues...people love to blame the drive...I don't think it has anything to do with the drive...I think that's kind of a cop out. Prisons have had a really negative effect on our communities.

Our school bus stops are right next to them; from where I'm sitting, if I open the windows and I'm quiet, I can hear the prison alarm and the school bells, you know from the high school...the community is incredibly conservative... We don't have enough teachers for our traditional classrooms...our schools don't have math teachers as it is. The idea that they would be like, yay, I'll go (teach in prison)....yeah right, they just don't wanna do it.

Here is how a second program coordinator described their struggles with hiring:

Program Coordinator: So right now I have 18 teachers going in, which is phenomenal, but we are still missing like the core people. We still don't have math. We didn't have science except I found somebody that we hired from out of town that's really invested, so she's willing to drive to come and teach but it's a lab class, you can only do 15 at a time, and we have 500 students, that's going to take a lifetime. 
The most rural programs are set up to fail in terms of meeting the educational needs of their incarcerated community members - there simply is not enough diverse, willing, and highly-qualified faculty (particularly in these areas) to go around.

\section{The Absence of Disability Rights and Other Student Services}

One of the most concerning and unanticipated findings of this study is the extent to which incarcerated people with disabilities are being denied access to higher education programs. What I expected to find was a very high population of incarcerated students with disabilities participating in higher education programs who were not being provided with the accommodations for learning that they are legally entitled to...and I did: nearly $100 \%$ of the program coordinators that I formally and informally interviewed admitted, often with appropriate shame, that they provide NO services for students with disabilities. What I did not expect to find, is that incarcerated students with disabilities are being blocked from entering college programs from the start. Here is how one program coordinator explains this phenomenon:

Roam: How do you support students with disabilities in your program?

Program Coordinator: That's a good question. We used to... and then for years we wondered why nobody was seeking the services... and I think the reason our students don't is that we offer only the upper-division courses, and there are no supports for people with disabilities in the GED program or the community college program. 
So by the time a student gets to us, the students that could have used the help have been long discouraged and long abandoned along the way. I wish I could say something else, but that's what happens.

In every college program, the students that have the privilege of accessing community college programming in jails and prisons have survived an initial weedingout by a GED requirement enforced by correctional facilities. Repeatedly throughout our interviews, program coordinators claimed to have no students with disabilities that weren't visible (like paraplegia) in their programs, admitted to not having the budget or staff to offer these services, and/or blamed students for not wanting to 'come out' about their disability.

Here is one more interview excerpt from a program coordinator explaining their program's lack of support for students with disabilities:

...these students don't want to self-identify in there, like in orientation when I talk about DSPS nobody ever wants to speak to me on the side, like they will ask me a zillion other questions about citizenship or all these other things they don't want to talk about, but DSPS, they aren't going to talk about in a prison, in a level 4 maximum security...

This program coordinator also identifies CDCR policy as a barrier to even trying to meet the needs of incarcerated students with disabilities: 
When I was talking to DSPS I was like, I don't really know how to overcome that because even when I had a student that was visually impaired and I pulled him aside and I said hey is there resources that you need? You know, what do you need?

When we tried to provide him stuff we couldn't get any of it approved by the prison to go in. The only thing approved by the prison for him to have is a magnifying glass. Well that doesn't do anything. Well, how do you serve students like him?

This lack of infrastructure (or care) for incarcerated students with disabilities, and incarcerated students from additional, intersecting identities (like a student who is disabled and also poor, for example), can have detrimental impacts on student success across demographics named in most CCC's mandated equity plans. Another interesting finding that came up across interviews with program coordinators was the extent to which this lack of support also impacts classified staff at their institutions; this finding also raises important questions about the value and distribution of labor.

Student support programs like academic counseling and academic supports like peer tutors, student psychological services, library resources, and learning communities that are widely available on campus, are generally inaccessible to incarcerated students. Even worse, many of the program coordinators I interviewed both formally and informally were pained to disclose that their institutions are not hiring new counselors in 
EOPS, for example, but are expecting existing workers on campus to carry the additional burden of the increased workload caused by mass-enrolling incarcerated students. There is a robust thread in the CCCCO's listserv about this situation because no jail or prison in California allows incarcerated people to use the internet. As a result, the vast majority of incarcerated students fill out the paper version of the CCC application (CCC Apply); then, in most cases, a counselor (or another staff member) has to enter that information by hand and often has to track down these new students' transcripts-a costly process in terms of time and stress.

Most (if not all) of this additional, and often highly emotionally taxing, labor is taking place on the backs of counselors and classified staff, who are predominantly womxn and/or people of color doing this work in addition to their regular workload. In some cases, counselors were asked to volunteer to go into jails or prisons to enroll students directly and/or provide a skeletal orientation. In addition to these issues around the absence of critical student services and the distribution of labor, the course offerings in many programs are also problematic in terms of gender in/equity.

\section{Gender-biased Programming}

The vast majority of prison higher education programs in the nation exist in men's prisons; accordingly. the body of research about prison higher education is centered largely on the experiences of incarcerated men. There are virtually no studies about the impact of prison higher education programs on incarcerated womxn and queers. In 
addition to disparities in the quantity of offerings at men's vs. womxn's facilities, there are also disparities in the types of courses that incarcerated men and womxn are able to access. For example, many womxn's institutions have courses and programming focused on culinary, secretarial, and/or parenting skills - a throwback to the days of home ec. On the other side of that coin, incarcerated men mostly have access to programs involving manual labor (construction is by far the most common program offering). Even in jails, which typically house both men and womxn, all courses are divided based on gender. The men at the jail will get Forklift Operation or Hardscaping 101, and the womxn will get Office Skills or Customer Service 101; if there is a GED or community college program at the jail, the men take their courses separate from the womxn. Here is how one program coordinator described this gender bias in programming:

There's a Culinary program at the womxn's prison..., that's so sexist, right like no, they need transfer-level work... But at the same time, the prison invested thousands and thousands of dollars in programming, that's the most expensive program you could run, and then the women love it because they have such terrible access to quality food. With this Culinary program, they are eating like high quality food all the time.

So, to take away the culinary program from them would be devastating... Fine we have a culinary program that serves some great purposes, but then how do we build on that? 
As the California Community Colleges continue to expand programming in correctional facilities, it is critical that they are as concerned with providing high quality instruction and equity-driven opportunities in jails and prisons, as they are with enacting those same values on our college campuses.

\section{Implications for a Critical Trans Politics Approach to Equitable Programming}

No matter how hard we try, we will never be able to recreate in a prison or jail the truly transformative magic that happens in a college classroom with windows and technology and a multitude of races and genders present. California's incarcerated students who are currently being caged in industrial warehouse-style prisons in the middle of the desert belong in our classrooms, on our campuses, and in our communities with their loved ones. The need for radical inclusivity is a primary implication of this study. Being radically inclusive would mean including incarcerated folx in our communities and on our campuses, not keeping them hidden from view. We should reject manufactured narratives designed to ignite public fear about incarcerated peopleindividuals who are often mistaken for 'violent criminals', when they are not. In fact, more than two-thirds of the people held in jails have not even been tried or convictedthey just can't afford bail, so they are literally incarcerated for the crime of being poor (Vera, 2015). There is no reason many of these people should not be able to be in a college classroom instead of a jail cell. College programs that continue to work inside correctional facilities should focus on building strong AA programs, as well as a bridge 
to somewhere-ideally, offering students a pathway to a CCC and/or CSU campus. Many of our CSUs and UCs already have student-led clubs and programs aimed at helping system-impacted folx be successful on campus.

The CSUs are known across the globe for their high-quality reentry program, Project Rebound-it was incredible to hear colleges from other countries celebrating these programs as models at the (2018) European Prison Education Association's international conference. Until (like many other nations) we are able to get currently incarcerated students on actual campuses, programs that exist in correctional facilities should aim to have fully resourced student supports including, not limited to: Student Psychological Services, Academic Counseling, Academic Success Coaches, Disability Rights and Resources, Peer Tutoring, Financial Aid, Scholarships, Student Web Portals, Library Resources, as well as highly trained, resourced, reflexive, and diverse faculty who practice culturally relevant, problem-posing, and healing-centered pedagogies. Community colleges forming these types of partnerships should also be sharing resources (not competing for them) and should be producing our own research, not having research conducted by elite universities about us, without us.

Being radically inclusive would also mean that open access community colleges offer their services to the entire population of incarcerated humans-this includes those with disabilities, those in solitary, those in womxn's institutions, those without financial capital, those farthest from parole, those sentenced to life (or death), those who are 
un/documented, those who do not yet speak English, the elderly, and, yes, even those who committed the types of crimes society deems most abhorrent. Radical inclusivity should not just inform which prisoners are able to access programs, but should also inform what types of courses we offer. Radical inclusivity also means considering who is sitting in which types of classrooms. Being radically inclusive means prioritizing access to credit-bearing college courses for incarcerated students from historically marginalized groups in education, and providing everyone with access to rigorous college-level curriculum. Even in terms of CTE courses, womxn should have access to the Forklift Operating if they want it, and men should have access to Culinary Arts if they want it. Although our prisons are segregated by gender, our jails are not. There is no reason men and womxn in jails can't begin sitting together in classrooms immediately. There is also no reason that correctional officers interested in pursuing higher education could not be included as students in these same classes.

A final way of exercising radical inclusivity in our prison higher education partnerships would be paying system-impacted folks to lead this movement in both policy and practice. System-impacted individuals must have a (paid) seat at every table where decisions are made that will impact the educational experiences of system-impacted folx, which includes currently or previously incarcerated individuals, as well as their families and communities. Once more system-impacted folx have seats at the table, college programs can make more informed and more impactful decisions that will undoubtedly 
produce more equitable programming and outcomes. Gender, economic, and disabilitystatus aside, virtually no student in prison or jail today has any agency over their academic future, since incarcerated students are largely relegated to courses centered on passing the GED exam or on "workforce preparation." The tragically limited, potentially exploitative, scope of course offerings is another critical finding of this study pertaining to prison and jail higher education programming.

\section{Finding Area 3: Turf Wars Between GED, Workforce Prep, and Academic Pathways}

Across formal and informal interviews and conference panel sessions, many program coordinators and incarcerated students alike express deep concern with parity around quality and rigor between courses being offered on campus, and courses being offered in correctional environments. Below, I include three excerpts from interviews with longtime program coordinators; each excerpt demonstrates the ways in which program coordinators are wrestling the desire and/or ethical obligation to provide rigorous, academic programming in correctional facilities:

\section{Excerpt 1}

The students want to know, what are you doing different? And what they are really concerned about is, are you watering this down for us? Or are the books the same, the texts the same? - Program Coordinator Excerpt 2 
I ended up spending the next sixteen years trying to make sure that this became a program where people really learned to write. You know and were ready...not just to get an AA, like a prison AA, but like a prepared to transfer to UCLA or Stanford or wherever they might want to go AA.-Program Coordinator

\section{Excerpt 3}

My reaction to the environment and to the program was so strongly informed by my own educational background because I was just sort of like, wait, if we are not holding them to the same standard as we hold our students at Cal, can someone tell me why? (chuckling sarcastically) You know?

Like is it because we just don't know how to teach Composition? We are like a bunch of grad students and we just...or is it because it's just too much work or...is it because we think, I don't know, can like Black and Brown men at fifty really learn how to use a semicolon? You know it's kinda...they're kinda tricky (sarcasm). You know, is it just straight up racist low expectation? Is it...you know what 1 mean?-Program Coordinator

These three quotes demonstrate the concerns for parity, and for rigor, shared by many students and program coordinators in the field of prison higher education. In spite of our best efforts, it is, of course, impossible for faculty teaching in correctional facilities to keep everything the same as in the classes we teach on campus-no office hours, no email, no discussion board online between classes. There are countless ways an instructor 
has to alter any given course just to get it in the gates of a jail or prison. In addition to the many dynamics of incarcerated students' courses that are restricted, the pathway options are also far more limited compared to those of on-campus students. For example, although no community college in the state of California requires students to have a GED, most community college programs operating in jails and prisons do not admit students without the GED.

The origin of this requirement typically lies in DOC or CDCR, not in the community colleges_-but it plays out in college programs' enrollment nonetheless. Program coordinators also have no control over which incarcerated people have access to their program's course offerings - these decisions about who gets in are often arbitrary and are made by correctional officers without any background in education. The decision to make the GED a pre-req for college programs in correctional facilities is no differentneither has anything to do with what is actually best for the student, with what any given student is intellectually capable of achieving, or with what incarcerated students actually want. My own wrestling with this phenomenon at our local jail led me to a recurring, unexpected, and critical question: is the GED a valuable credential, and for whom? Since correctional institutions are mandating the GED, and tying public dollars to it, we should explore the value of this academic measure.

I brought this question to a prominent leader in California public higher education research and policy, and they replied with a chuckle: "Hah. The GED is a historical 
hangover," describing it as something we sentimentalize only for certain people and certain types of jobs, even though it has no actual value in society as a measure of an individual's academic competence. Similarly, in the college classroom on a campus, just because a student shows up with their GED or high school diploma, does not mean that student is prepared for any given college class. The following dialogue that took place in my own classroom with an incarcerated college student reflects this claim:

Clayton: I could barely read when I graduated high school, can you believe that?

Roam: How did that happen?

Clayton: They just pushed me through. Year after year. I would hardly show up, and every teacher still passed me on. Then, I got kicked out halfway through my senior year of high school. The principal gave me a huge stack of packets and said I could still graduate if I completed the packets before the end of the year. So, I had my mom complete the packets and they graduated me"-Clayton, incarcerated student. Neither passing the GED, or graduating high school, guarantees that any student enters any college classroom with a requisite level of skills. This begs the question, why should the GED or high school diploma be a barrier to higher education for incarcerated students, especially when it is not an impediment for individuals seeking higher education on an outside campus? I asked many of the program coordinators I interviewed 
both formally and informally about this, and they all had similar responses. Here is a demonstrative excerpt from a formal interview with a program coordinator: Roam: An education policy expert I spoke with recently referred to the GED as an historical hangover. What do you think about that? And what do you think about the GED as an entry requirement for prison higher education programs?

Program Coordinator: I completely agree with that. With the GED, it's valuable if you are just trying to get some entry level basic job, but these guys essentially, I've gotten to know them very well, I'm sure you have too, they're incredibly strong, incredibly intelligent, and a lot of them are natural born leaders that are just lost. How do we take that and utilize that toward a higher quality education?

This program coordinator is questioning the GED as a valid credential for meaningful work, but she's also exposing the ways that our too-limited assumptions about the intellect, drive, and academic potential of incarcerated students prevents these individuals from accessing the types of transformational educational and life experiences that many of us enjoy. This situation exists largely because state and federal policy require that correctional facilities provide GED programming; there is also funding tied to these types of programs. If the jails and prisons allow students to enroll directly in college courses. correctional facilities miss out on the available funding for offering GED 
programming and could potentially be found in violation of federal and/or state mandates. Correctional institutions often hire from within to run these (GED/Adult Education) programs, and so the introduction of outside college programming can also be a direct threat to the livelihood of correctional staff. Here are excerpts from interviews with three different program coordinators that illustrate the climate of competition among service providers:

\section{Excerpt 1}

What (CDCR) will do is, students are not allowed to get a milestone or educational merit credit lf they don't have the GED because the prisons or CDCR gets some kind of apportionment for the GED, so it's not in their best interest to put them in to college without it. I guess in theory, it's good to have the GED first, but if they're doing all the self-teaching in their cells (because the GED teachers and curriculum are less than uninspiring), are we creating more obstacles, or are we getting pen and paper and numbers so we can get a certain payment? Or is it really beneficial?

\section{Excerpt 2}

To be honest with you, GED and everything that goes with Adult Basic Education is the responsibility of $C D C R$, it's not the responsibility of the community college. We would rub up against a lot of labor politics for us to 
focus on the GED, so most of the community colleges that I'm aware of are focused on the local AA degree or the AA degree for transfer or Career Technical Education, which is a little iffy because it has to be Career Technical Education that isn't already being offered in the prison. Excerpt 3

We chose to work out of a prison that had a very robust vocational and academic community college presence because... it was clear that we could not offer the lower-division courses ourselves... we were told not to do that, not to compete with the community colleges because the community college made money from the contract, so we were discouraged from offering a class that might be seen as competing with their class. - Program Coordinator

Colleges and universities working in partnerships with jails or prisons are often forced to defer decisions about admissions to correctional officials. This practice is absurd, since the vast majority of CDCR employees have no experience in higher education. As a result, even though free-world students can take classes at colleges and universities without first passing the GED or having a high school diploma, incarcerated students without the GED or diploma are blanketly denied access to college programs in jails and prisons. 
In addition to imposing a GED requirement on incarcerated students, formal and informal interviews and conversations revealed many other reasons correctional officers might deny a prisoner's access to college programming including: officers' negative bias/deficit mindset about a prisoner's ability or potential, officers' fear of diminishing job security, officers' resentment of prisoners receiving free higher education, officers' personal grudges against particular types of prisoners or an individual prisoner, officers' mis/perception of prisoners' motivation for attending college, the prisoner's discipline record, the type of crime committed by the prisoner, the security-level of the yard a prisoner lives on, the age of a prisoner, the length of a prisoner's sentence, the prisoner's proximity to release date, and a host of other arbitrary (and ethically questionable) qualifiers. The theme of correctional officers, and CDCR/DOC policy and practice, as barriers to incarcerated students' access to higher education surfaced relentlessly across conversations and conference spaces. In addition to the debate surrounding the GED, there is also some contention around the modes of college programming being offered in carceral facilities.

Historically, there has been a trend of colleges and universities exploiting prison and jail populations by charging tuition for inferior renditions of on-campus coursesoften taught under titles like "Independent Study", "Distance Education", or "Correspondence Courses". In many of these types of programs, the higher education institution collects full tuition without providing students with full supports, and without 
caring about the quality of curriculum or students' rates of persistence and completion. The expansion of programs in California booming while the CCCs are facing dire enrollment and budget crises, increases the likelihood of returning to these types of potentially exploitative practices. A contemporary and more nuanced manifestation of these practices is the focus on Adult Education and Workforce Preparation, as opposed to fully funding academic pathways and true CTE programs. There is a great deal of tension around this specific issue in California, where most community colleges are not willing to support full academic offerings and student services in correctional facilities, but are willing to collect apportionment funding for enrolling students in watered-down versions of CTE and certificate courses under the loose umbrellas of Adult Education and Workforce Preparation.

Here is what one previously incarcerated $\mathrm{PhD}$ student had to say about her experience with Workforce Prep during her incarceration; I included a lengthy excerpt from this interview questions because she addresses so many critical issues in this single response:

Workforce prep is shit. And you can quote me on that. It's nice, but it's not going to transform large swaths of reentering individuals or communities, much less the country. If that's the best you can offer is some meaningless, alienating, wagelabor job, people who are incarcerated are going to find other means to get by. 
First of all, those jobs, you barely get by financially. And just the brazen...the kind of dead end fields for those jobs that don't provide a real blueprint for any progress...there are people inside where that's not enough. Workforce prep is not enough to transform their life, and it's not going to be enough... some people want to have purpose... they have to have the option to have purpose - womxn, in particular, face deep institutional and social barriers to living a llfe of purpose.

This student first comments on the lack of transformational capacity workforce prep programs have, then she predicts the ways in which workforce prep is a diversion away from meaningful work and living - a problem she knows first-hand that most incarcerated womxn face. These are critical findings about how incarcerated students might actually view the limitations of their own education options. Community colleges that offer workforce prep to the exclusion of academic pathways are in jeopardy of reproducing social inequality in myriad, deeply consequential ways.

Institutions of incarceration and education alike, are built on foundations of gendered and racial capitalism (Alexander, 2010; Davis, 2003). Institutions of criminal justice and education also produce exactly the results they were designed to reproduce: White supremacy, cis-heteropatriarchy, and the exploitation of poor and working class labor. Our prison and jail higher education partnerships that offer (only the most privileged) incarcerated students access to Workforce Preparation and Adult Education to 
the exclusion of academic pathways and true CTE, reproduce harmful narratives of personal responsibility (they just need to get a job so they can stay out of prison/jail). This line of thinking, of placing the responsibility solely on the individual, lets communities and systems (like schools and criminal justice) escape the shadow of their own complicity in bolstering the prison industrial complex.

One federal higher education policy expert illustrates this nefarious relationship between vocational education and the prison industrial complex:

Policy Expert: Washington recently reversed its ban (on Pell). It's a challenge for a lot of places because trying to reverse that against the constituents voices that don't understand, and the different interests have pushed some of the college access more on the vocational side, which has been where that has placed folx that have been incarcerated for the past twenty or thirty years or so...especially when you are in this conversation it's always about vocational, unfortunately. There are immediate needs and immediate realities to folx needing to get a skill in that regard, but there is also the legacy of having this prison industrial complex that's exploiting prison labor.

This policymaker illuminates three important dynamics of the debate about what types of education programming incarcerated students should be able to access. First, he comments on how these programs often exist in conflict with public (constituents) values; meaning, a public that has to pay, and often cannot pay, for higher education is often 
resentful of the idea of free higher education for incarcerated folx. Second, he uses the term vocational, as opposed to Career and Technical Education, because constituents are far more supportive of sending incarcerated folx into low-wage, low-joy work than they are of sending incarcerated folx to get an education that leads to a life of deep meaning and great prosperity. Finally, he draws direct connections between the focus on workforce preparation in prisons and jails and America's reprehensible and historical practice of exploiting human prison labor for corporate profit (the prison industrial complex).

California is in the midst of a strong push to renew/reinvigorate its workforce by directing millions of dollars to a "Strong Workforce Program", focused on "increasing the number of students enrolled in programs leading to high-demand, high-wage jobs..." and, "on data-driven outcomes rather than activities, along with an emphasis on innovation and risk-taking. In this way, colleges can be more responsive to labor market conditions and student outcomes" (CCCCO, 2018). Let's be honest: these types of workforce development programs are not being designed to funnel wealthy, White university students into the labor market. Below, I include an excerpt from an interview with another federal policy expert that reflects the tension around workforce preparation programs in correctional facilities: 
Policy Expert:...this policy debate was going on for a long time and one of the breakthroughs they had when they were able to pass it was giving it more of a workforce bent to the legislation.

So they agreed to restore funding for prison education programs, but they had to have a connection to the workforce. So that was kind of open-ended in the legislation, I've read it...you can make a lot of different arguments for what is a workforce program and what isn't, but a lot of that boils down to what happens in practice in these programs at a more local, institutional level.

Roam: What are your thoughts about workforce prep taking place in lieu of academic programming?

Policy Expert: Thinking just about policy, sometimes, often, you do have to make compromises in order to have policy pass. Especially when you are working in a place like Washington State where you have a mix of both liberals and conservatives...even outside of the context of prison higher ed, often workforce is something that both Republicans and Democrats can get behind. I think sometimes the policy strategy can be, take the win that you can get and keep moving forward. 
...As far as thinking about the value of higher ed, obviously there's value in all programs, yes, there can be bigger goals, but sometimes from the policy angle you have to work in smaller steps to get there.

It is significant to note that the first policy expert was a Black, male, and his responses were embedded in a critical approach that considered the need to pass legislation that disrupts the prison industrial complex or that at least doesn't reproduce it. Conversely, this second White, femxle policy expert speaks from a distanced, acritical perspective and talks about the need to compromise and the importance of taking "small steps" so as not to offend people still disturbed by the images of free higher education and meaningful lives for incarcerated members of our communities. Our current political climate, and our histories of slavery and racial capitalism, have direct impacts on which types of people have access to higher education that is not focused on work; this is the heart of recent highly controversial policy decisions in California like AB 705, Performance-Based Funding, and Guided Pathways —all measures aimed at expanding minoritized groups' access to higher education.

Another finding of this study that emerged in informal interviews, in conference panels, and in that is currently a hot-topic on the inmate-ed listserv, is the extent to which correctional facilities' reliance on prisoner labor interferes with incarcerated students' ability to participate in higher education programming. Here is a recent inquiry from the listserv: 
Hello Everyone,

I was wondering if anyone has been able to keep their face to face classes during the daytime without losing students to work assignments? From my understanding there has been an issue with the SOMS program and our students cannot work and go to school at the same time. Is there a program that has been able to avoid the conflict with SOMS?

Any insight into solving this problem would be greatly appreciated!

The SOMS is the "Strategic Offender Management System" that keeps track of prisoners' work and program schedules. Across conference panels, informal conversations, and interviews with program coordinators, the challenge of scheduling was a theme that surfaced repeatedly — specifically, the difficulty of scheduling classes in correctional facilities around prisoners' work schedules. Program coordinators articulated this challenge at a CDCR session held at the most recent 2018 summit for California prison higher education practitioners, "Leading the Nation: Building Excellence for California's Incarcerated and Formerly Incarcerated College Students." When asked how CDCR might accommodate the schedule of growing prison higher education programs, a CDCR representative responded by saying that, as more education opportunities for 'inmates' become available, this means fewer inmates are available for CDCR's "workforce"; in particular, this CDCR officer cited "lots of construction projects going on right now." It is deeply troubling that incarcerated members of our communities are 
denied access to education opportunities in order to provide labor that expands both the physical and economic capital owned by $\mathrm{CDCR}$, in effect, bolstering the same prison industrial complex that is responsible for brutalizing their/our families and communities.

In the next section, I offer implications for a critical trans politics approach to the conversation about incarcerated students' access to rigorous and transformative experiences in higher education.

\section{Implications for a Critical Trans Politics Approach to the GED/Workforce Prep/Academic Pathway Divide}

This is a crucial time to be having this conversation, as the current administration recently commented on the relationship he is trying to create between community colleges and the workforce:

You learn mechanical, you learn bricklaying and carpentry and all of these things. We don't have that very much anymore. And I think the word "vocational" is a much better word than in many cases a community college. A lot of people don't know what a community college means or represents. So we're working very hard on vocational schools, so when all of these companies move into this country, we're going to have a workforce that knows exactly what they're doing (Trump, 2018) 
In response to the Trump administration's ambitions of merging the education and labor departments, Mike Rose (2017) responded in a personal blog post with this call for a highly integrated approach to Career and Technical Education:

Under President Donald Trump and Education Secretary Betsy DeVos, education will likely be defined in functional and economistic terms - as preparation for the world of work. Vocational education will be reduced to narrow job training, a limited kind of education that has, sadly, characterized VocEd at times in its past, but that a lot of people have been working against over the last few decades. . .

Intellectual suppleness will have to be as key an element of a future Career and Technical Education as the content knowledge of a field. The best CTE already helps students develop an inquiring, problem-solving cast of mind. But to make developing such a cast of mind standard practice will require, I think, a continual refining of $\mathrm{CTE}$ and an excavation of the beliefs about work and intelligence that led to the separation of the academic and the vocational course of study in the first place.

Community colleges are creating new courses and departments (like Workforce Preparation, Hospitality, or Adult Education) designed with incarcerated students in mind, with the specific intent to focus course content on preparation for the workforce-a focus on job-training, as opposed to an integrated (CT) education that cultivates 
intellectual dexterity and critical thinking, reading, and writing skills. Our open access community colleges should be wary of any aim to reduce the function of higher education to workforce preparation, but it is utterly nefarious to design these types of programs specifically for incarcerated people.

One of the most important implications of this study is the need to abolish the GED — as a 'desirable credential' for employers, but more important, as a barrier to college programming for incarcerated students---especially since we do not require freeworld students to have the GED in order to enroll in our open access community college courses. Most educators agree that a standardized test does not measure mastery, potential, or ability. The GED is only a desirable credential to certain types of employers, like fast-food and retail. Here is an excerpt from an informal interview with a correctional officer that, in my experience, largely reflects how CDCR views the function of education for incarcerated folx:

A lot of the individuals that are incarcerated in the jail have such a history that they're going to walk in to try to get a job like even at Burger King or anywhere, and because of the criminal background of that individual, that employer is gonna go, see ya.

This begs the question, should we be relegating incarcerated folx to these types of low-wage, low-consistency, low-joy employment opportunities? If incarcerated students are unable to pass this high-stakes, standardized test, they are unable to access college 
courses in correctional facilities, which of course, disproportionately impacts students with disabilities and students from otherwise minoritized groups, effectively forcing them into the types of jobs those of us with tremendous privilege often go to college to avoid. The question here is not how can we get more diverse students to pass the GED, but why are we hanging on to such an archaic and ineffective instrument at all? And, why are we only imposing it on the poorest, most disenfranchised members of our communities instead of supporting their access to higher education? We could also consider ban the box legislation that would prohibit the kind of discrimination system-impacted folx face in the world of work.

In addition to removing the GED as a barrier to college programming, correctional officers should also be removed from the admissions process. As noted in the previous section, myriad data sources affirm that correctional officers often determine a prisoner's ineligibility for programming using arbitrary reasons, personal bias, or worse, because attending college courses might interfere with the prisoner's work schedule at the correctional facility. Not only do prisoners in California work maintenance and construction projects inside their carceral facilities, but private corporations (Victoria's Secret, Whole Foods, McDonald's, Wal-Mart, AT\&T, etc.) also exploit prison labor (Anonymous, 2017). Even California's (again) blazing wildfires are fought by womxn prisoners often earning less than one dollar per day (Democracy Now, 2017). Because of this direct conflict of interests. colleges should have full say in who gets admitted to 
college programs. An additional conflict of interest arises because programs that actually decrease recidivism are direct threats to the livelihood of correctional officers. To be explicit, everyone should be admitted on the inside that would be admitted on the outside, and that's supposed to be, literally, everyone when we are talking about open access community colleges.

In addition to removing barriers to access, there is great work to be done to improve the college programs that we are building for incarcerated people. Community colleges are fundamentally building the bike as they ride it, when they are creating programs in response to workforce demands, to demands being made by correctional agencies, or to an emergency state of precarity (of resources, field, education, enrollment, etc.); community colleges should articulate their own motivations and values and then develop infrastructure accordingly. In order to move forward in a way that is not unintentionally exploitative, programs must slow down, acknowledge the very real history of slavery embedded in the prison industrial complex, and be deliberate about not perpetuating the same system. We must also acknowledge the undeniable connection between the exclusionary, often predatory, education policies and practices that have made our graduations and senators predominately White and wealthy, and our prisons predominately people of color and poor people. We owe incarcerated members of our community the transformative education experiences that most of them were denied as children. There is an incontrovertible body of research documenting a public school to 
prison pipeline that targets queers and people of color; I discuss this literature in depth in chapter 1. A jail/prison-to-college pipeline is one way of making reparations for this pervasive history of abuse and exploitation, and community colleges have the opportunity to determine whether that pipeline lands these students in programs that prepare them only to be low-wage, low-joy workers, or programs that prepare students to be active participants in healthy families, communities, professions, and democracies.

Being transformative means reckoning with America's history of slavery, as well as managing our (false) stereotypes about incarcerated people; for example, opening up course offerings beyond certificates and degrees focused on "Business" because, you know, incarcerated people are such natural entrepreneurs, or on "Drug and Alcohol Counseling" because it's something they can really relate to. We should be offering programs in STEM, Ethnic Studies, Public Health (like Bard College!), Gender and Sexuality Studies, Philosophy, Psychology, Art, and all of the other disciplines that have moved the hearts and minds of so many (historically White, wealthy, cis-hetero, male, free people). Here is the voice of one student who experienced workforce prep programs while incarcerated:

What you're trying to do is of utmost importance-while people are incarcerated they can be inspired... and you are not going to be inspired by some kind of low-wage work training. 
They are going to get inspired by reading literary pieces.

They're going to get inspired by reading the type of mentally

challenging pieces that are provided in upper-division courses. -

System-Impacted Student.

California can do better than a strong workforce: we can build strong communities by investing and divesting according to a framework of values that privileges the wellness of people and planet over corporate profit.

Additionally, college faculty are not arms of the police state-is not our responsibility to reduce recidivism or save the state money that can then be used to expand police and policing. This specific theme surfaced in several ways across interviews and conference panels. Here are a couple of excerpts that demonstrate how two leading program coordinators describe their motivations for starting college programs in jails and prisons, which are often not aligned with the motivations of their college or partner correctional institution:

\section{Excerpt 1}

We do education-not anti-recidivism work. That is our measure. How many do we get educated. Not how many do we get jobs. -Program

Coordinator

Excerpt 2 
To be clear, and this is true across most of the field of prison higher educators: the 'measures of success' we want our programs judged by have nothing to do with recidivism or with saving money for the state or solving our college's enrollment crisis. - Program Coordinator

These excerpts also demonstrate the enormous pressure, as well as the huge social implications, for California's prison higher education partnerships. Moving forward, it is critical that the community colleges are explicit about the aims of these programs, so that the success of these programs is gauged by the appropriate measures. The measures for the success of these programs should be determined by the students, faculty, and coordinators doing the work of building these programs from ground.

\section{Conclusion}

Our job, as open access community colleges, is to provide high quality education that empowers students to live their healthiest, most meaningful lives, and engages their participation in a diverse and participatory democracy. I will close this section with one final interview excerpt from a model Prison BA program's that describes how they move beyond individual transformation in college classrooms, to also transforming democracy:

Right now we are involved at the state level and some local programs in some legislative efforts that would support our students on the outside, and this is where we see our advocacy efforts/energy going. 
So, one of these bills would ban the box for public institutions in the state, and the other would require that the department of corrections provide information about voting to people on release, because in our state, you can vote after you come home and a lot of people don't know that. So that would open the door for us to not just support the distribution of these materials, but to engage in some voter education and related efforts.

It's a good opportunity for us-and we've already been doing this-we bring in state legislators and elected officials to the prison and have them speaking to the guys as voters, which they soon will be. So we see ourselves getting increasingly involved in legislative work, in advocacy work, directed towards supporting our students on the outside... you know, supporting our alumni on reentry.

This program coordinator answers Freire's call for educators to live their politics and serves as a call-to-action for practitioners involved with prison higher education partnerships in any capacity. I thought that this was a pertinent quote for my conclusion because it embodies the truly transformational capacity of our prison higher education partnerships, which has as much to do with transforming individual hearts and minds as it does with abolishing institutions and practices that harm our students, our communities, and our democracy. This dissertation outlines some of the most critical tensions manifesting in California's prison higher education partnerships and offers implications for practitioners committed to providing the same humanizing, high-rigor, high-support 
programs in our correctional facilities that we aim to provide on our campuses.

California's prison and jail higher education partnerships have enormous potential to enhance the lives of system-impacted members of our communities, as well as the direct potential to improve the condition of our democracy. This responsibility is tremendous, and quite precious, which makes it imperative that community colleges create prison higher education programs that are aligned with the humanizing and democratizing values of California's open-access community colleges. 


\section{References}

Alexander, M. (2010). The New Jim Crow. The New Press. New York.

Alexander, M., Klein, N., \& Taylor, K. (2017). "In Conversation". Haymarket Books.

Almeida, J., Johnson, R.M., Corliss, H.L., Molnar, B.E., \& Arazel, D. (2009). Emotional distress among lgbt youth: The influence of perceived discrimination based on sexual orientation. Journal of Youth and Adolescence. 38. 1001-1014.

Anderson-Zavala, C., Beckham, K (Chair) Meiners, E. R., Pour-Khorshid, Farima, Stovall, D. O. (2008, April). Building the Radical Imaginary Now: Abolitionist Practices and Movements to End Our Carceral State. Working Group Roundtable conducted at the American Education Research Association National Conference, NY, NY.

Annamma, S. (2017). The Pedagogy of Pathologization: Dis/abled Girls of Color in the School-prison Nexus. Routledge.

Anonymous. (2017). "50 Companies Supporting Modern American Slavery". Caged Bird.

Birkett, M., Espelage, D.L., \& Koenig, B. (2009). LGB and questioning students in schools: The moderating effects of homophobic bullying and school climate of negative outcomes. Journal of Youth and Adolescence. 38. 989-1000. 
Bourdieu, P. (1977). Cultural reproduction and social reproduction. In J. Karabel \& A. H. Halsey (Eds.), Power and ideology in education (pp. 487-511). New York, NY: Oxford University Press.

Bourdieu, P., \& Passeron, J. (1977). Reproduction. London u.a.: 1990.

Brown, K., \& Nash, C (2016). Queer Methods and Methodologies: Intersecting queer theories and Social Science Research. Routledge.

"California Budget Includes \$5 Million for Incarcerated and Formerly Incarcerated Community College Students." (2018). The Opportunity Institute. [Media release].

Charmaz, K (2015). Constructing Grounded Theory. 2nd ed. Sage Publications.

Charmaz, K. (2017). "The Power of Constructivist Grounded Theory for Critical Inquiry." Qualitative Inquiry. 23(1). 34-45.

Chen, Michelle (2018). “Beware of Big Philanthropy's New Enthusiasm for Criminal Justice Reform: Wealthy donors across the political spectrum are zeroing in on our jails and prisons as the latest locus of privatization." The Nation.

Community colleges: inmate education programs: computation of apportionments, SB1391, (2014).

Community colleges: maximize probability that a student will enter and complete transfer-level coursework in English and Math in one year, AB 705, (2017).

Davis, A. (2003). Are Prisons Obsolete? Seven Stories Press. New York. 
D’Augelli, A.R., Grossman A.H., Starks M.T. (2006). Childhood gender atypicality, victimization, and PTSD among lesbian, gay and bisexual youth. J Interpers Violence. 21(11): 1462-1682.

de Bry, T. (1594). Engraving.

Democracy Now. (2018). "Why are Women Prisoners Battling California Wildfires for as Little as $\$ 1$ a Day?" [Report].

Erzen, T., Lewen, J. (moderator), McDowell, L., Van Heydoorn, B., and Wall, T. "Funding Challenges in the Field of Higher Education in Prison: Pell and Beyond: A Panel Discussion". The National Conference for Prison Higher Education. 2017.

Freire, P. (1970). Pedagogy of.the oppressed. Jakarta: LP3ES.

George, R., \& West, C. (2016). "The Examined Life". American Enterprise Institute.

Ginwright, Shawn. "The Future of Healing: Shifting From Trauma Informed Care to Healing Centered Engagement". Medium. 2018.

Giroux, H. A. (2017). America at war with itself. San Francisco: City Lights.

Giroux, H. (2015). "The Curse of Totalitarianism and the Challenge of an Insurrectional Pedagogy". CounterPunch.

Girshick, L. (2011). Out of compliance: Masculine-identified people in women's prisons. Captive genders: Trans embodiment and the prison industrial complex, 189-208. 
GLSEN National School Climate Survey. (2015). "LGBTQ Students experience pervasive harassment and discrimination, but school-based supports can make a difference".

Hackimer, L., \& Proctor, S.L. (2015). Considering the community influence for lesbian, gay, bisexual, and transgender youth. Journal Of Youth Studies. 18(3). 277-290.

Hershberger, S.L., \& D'augelli, A.R. (1995). The impact of victimization on the mental health and suicidality of lesbian, gay, and bisexual youths. Developmental Psychology. 31. 65-74.

H.R., (1994). 103rd Cong., U.S. G.P.O. [Enacted].

Huebner, D.M., Thoma, B.C., \& Neilands, T.B. (2015). School victimization and substance use among lesbian, gay, bisexual, and transgender adolescents. Prevention Science: The Official Journal Of The Society For Prevention Research. 16(5). 734-743.

Kosicw, J.G., Greytak, E.A., Palmer, N.A., \& Boesen, M.J. (2014). The 2013 National School Climate Survey: The experiences of lesbian gay bisexual and transgender youth in our nation's schools. New York: GLSEN.

Kosciw, J., Palmer, N., \& Kull, R. (2015). Reflecting Resiliency: Openness About Sexual Orientation and/or Gender Identity and Its Relationship to Well-Being and Educational Outcomes for LGBT Students. American Journal of Community Psychology. 55(1/2). 167-178. 
Lawston, J. \& Meiners, E. (2014). "Ending Our Expertise: Feminisms, Abolition and Scholarship." Feminist Formations 26(2).

McGuire, J. K., Anderson, C. R., Toomey, R. B., \& Russell, S. T. (2010). School climate for transgender youth: A mixed method investigation of student experiences and school responses. Journal of Youth and Adolescence, 39(10), 1175-1188.

Meiners, E. (2016). For the Children? Protecting Innocence in a Carceral State. University of Minnesota Press.

Meiners, E. (2007). The right to be hostile: Schools, prisons and the making of public enemies. Routledge.

Mogul, J. L., Ritchie, A. J., \& Whitlock, K. (2011). Queer (in)justice: the criminalization of LGBT people in the United States. Boston, Mass: Beacon.

Morris, M. W., Conteh, M., \& Harris-Perry, M. V. (2018). Pushout: The criminalization of Black girls in schools. New York: The New Press.

Nance, J. (2016). "Students, Police, and the School-to-Prison Pipeline”. 93 Wash. L. Rev. 919

"No Justice No Pride". (2017). [Facebook Album].

"Organizational Structure". Education Justice Project.

Oswald, R.M., Blume, L.B., \& Marks, S.R. (2005). Decentering heteronormativity: A model for family studies (p. 143-165). Sourcebook of family theory and research. Thousand Oaks: Sage. 
Oswalt, S. B., \& Wyatt, T. J. (2011). Sexual orientation and differences in mental health, stress, and academic performance in a national sample of U.S. college students. Journal of Homosexuality, 58(9), 1255-1280

Parry, Marc. "Universities Are Hotbeds of Scholarship on Mass Incarceration. But Are They Doing Enough to Fix the Problem?". The Chronicle of Higher Education. 2018.

Poteat, V. P., Scheer, J. R., \& Chong, E. S. (2016). Sexual orientation-based disparities in school and juvenile justice discipline practices: Attending to contributing factors and evidence of bias. In Inequality in School Discipline (pp. 61-78). Palgrave Macmillan, New York.

"Program Directory". (2018). Corrections to College. [website]

Richie, B. E. (1996). Compelled to crime: the gender entrapment of battered Black women. New York: Routledge.

Ritchie, A. (2017). Invisible No More: Police Violence Against Black Women and Women of Color. Beacon Press. Boston, Massachusetts.

Rose, M. (2017). "Who Should Go to College?: Unpacking the College-for-All Versus Occupational Training Debate". [Blog].

Santa Rosa Junior College. Schedule of Classes. (2018).

Sheldon, J. (2010) "(Re)Searching Queer Subjects: Approaching a Queer Methodology". AERA. [Paper Presentation] 
Shor, I., \& Freire, P. (1987). What is the "dialogical method" of teaching? Journal of Education, 169 (3), 11-31.

Smith, A. "No Bottom Yet in 2-Year College Enrollments." Inside Higher Ed. (2018).

Smith, C. (2017a). "Complex Sentences: Searching for the purpose of education inside a Massachusetts State Prison". The Harvard Educational Review. 87(1), 81-98.

Smith, C. (2017b). "The Lifelong Learning of Lifelong Inmates". The Atlantic.

Snapp, S. D., Hoenig, J. M., Fields, A., \& Russell, S. T. (2015). Messy, butch, and queer: LGBTQ youth and the school-to-prison pipeline. Journal of Adolescent Research, $30(1), 57-82$

Spade, D. (2015). Normal life: administrative violence, critical trans politics, and the limits of law. Durham: Duke University Press.

Spade, D. (2016). "When we win we lose: Mainstreaming and the redistribution of respectability." Lecture presented at CLAGS 2016 Kessler Award Lecture. Retrieved from https://www.youtube.com/watch?v=VNKTX6RqTIM

Stanley, E. A., \& Smith, N. (2015). Captive genders: trans embodiment and the prison industrial complex. Edinburgh: AK Press.

Stonewall Uprising. (2011) PBS.

Stovall, D. (2015). Mayoral control: Reform, whiteness, and critical race analysis of neoliberal educational policy. What's race got to do with it?: Understanding 
racism, neoliberalism and education reform. (Bree Picower and Edwin Mayorga eds.). New York: Peter Lang

Toomey, R.B., Ryan, C., Diaz, R.M., \& Russell, S.T. (2011). High School Gay-Straight Alliances (GSAs) and Young Adult Well-Being: An Examination of GSA Presence, Participation, and Perceived Effectiveness. Applied Developmental Science. 15(4). 175-185.

US Department of Education. (2014). "A First Look: Key data highlights on equity and opportunity gaps in our nation's public schools". [Report].

Wang, J. (2018). Carceral Capitalism. South Pasadena, CA: Semiotext(e).

"What is Strong Workforce". California Community Colleges Doing What Matters'for Jobs and The Economy. (2016). 